\title{
Littoral Processes: U.S. Coast Guard Station, Fort Point, San Francisco
}

\author{
R. M. Ecker \\ G. Whelan
}

October 1983

Prepared for

the U.S. Coast Guard

under Contract DE-AC06-76RLO 1830

Pacific Northwest Laboratory

Operated for the U.S. Department of Energy

by Battelle Memorial Institute 


\section{DISCLAIMER}

This report was prepared as an account of work sponsored by an agency of the United States Government. Neither the United States Government nor any agency thereof, nor any of their employees, makes any warranty, express or implied, or assumes any legal liability or responsibility for the accuracy, completeness, or usefulness of any information, apparatus, product, or process disclosed, or represents that its use would not infringe privately owned rights. Reference herein to any specific commercial product, process, or service by trade name, trademark, manufacturer, or otherwise, does not necessarily constitute or imply its endorsement, recommendation, or favoring by the United States Government or any agency thereof. The views and opinions of authors expressed herein do not necessarily state or reflect those of the United States Government or any agency thereof.

\section{PACIFIC NORTHWEST LABORATORY operated by \\ BATTELLE \\ for the \\ UNITED STATES DEPARTMENT OF ENERGY under Contract DE-AC06-76RLO 1830}

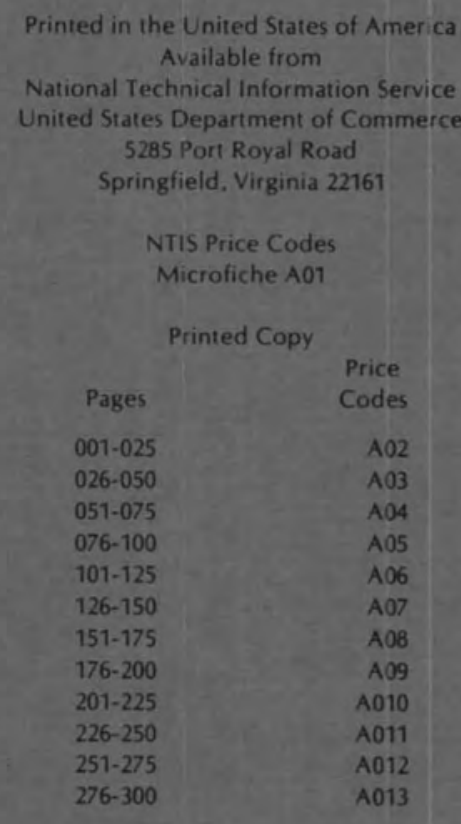


LITTORAL PROCESSES: U.S. COAST GUARD STATION, FORT POINT, SAN FRANCISCO

R. M. Ecker

G. Whelan

October 1983

Prepared for

the U.S. Coast Guard

under Contract DE-AC06-76RLO 1830

Pacific Northwest Laboratory

Richland, Washington 99352 


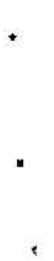




\section{CONTENTS}

INTRODUCTION.................................................. 1

PHYSICAL SETTING.......................................... 5

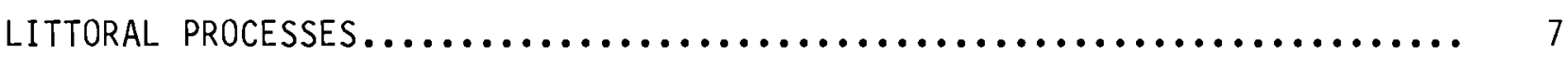

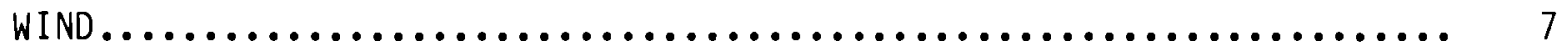

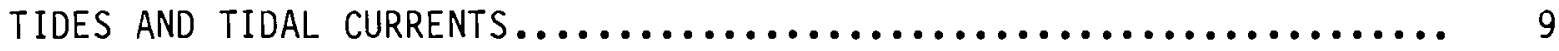

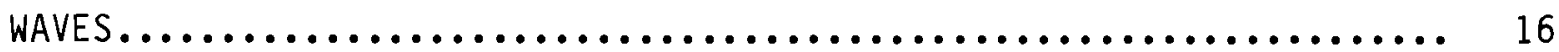

Wind-Generated Waves.................................. 16

Long-Period Waves................................... 20

SUMMARY OF WAVE CONDITIONS AT FORT POINT STATION.............. 45

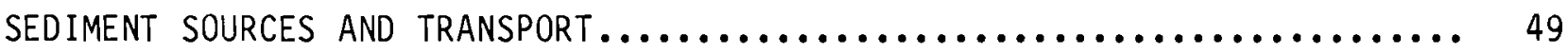

SOURCES OF BEACH SEDIMENTS $\ldots \ldots \ldots \ldots \ldots \ldots \ldots \ldots \ldots \ldots \ldots \ldots \ldots \ldots, 49$

LONGSHORE SEDIMENT TRANSPORT $\ldots \ldots \ldots \ldots \ldots \ldots \ldots \ldots \ldots \ldots \ldots \ldots \ldots, 50$

Longshore Sediment Transport By Waves.................... 50

Sediment Transport Due to Currents....................... 53

ALL-WEATHER MOORINGS DESIGN ALTERNATIVES, FORT POINT STATION.......... 57

SHORE-CONNECTED BREAKWATER $. \ldots \ldots \ldots \ldots \ldots \ldots \ldots \ldots \ldots \ldots \ldots \ldots \ldots, 58$

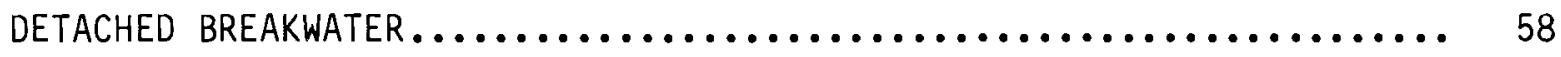

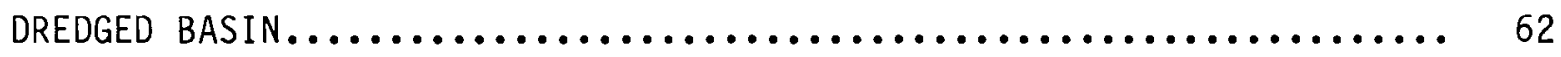

DESIGN CONSIDERATIONS - FORT POINT STATION...................... 65

DESIGN WAVE HEIGHT..................................... 65

CREST ElEVATION OF STRUCTURE $\ldots \ldots \ldots \ldots \ldots \ldots \ldots \ldots \ldots \ldots \ldots \ldots \ldots .67$

WAVE HEIGHTS WITHIN ALL-WEATHER MOORINGS BASIN............... 67

Wave Transmission Through Structure and Resonance............ 67

Wave Diffraction Within Basin.......................... 68 
LONGSHORE SEDIMENT TRANSPORT AND SHORELINE READJUSTMENT.......... 69

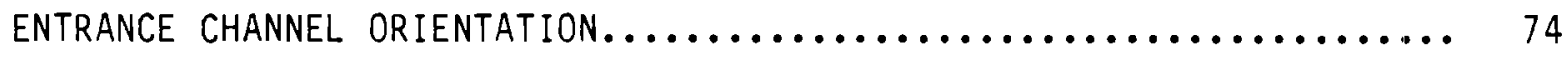

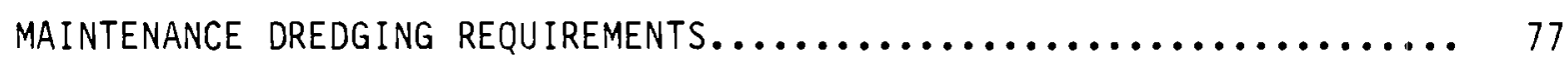

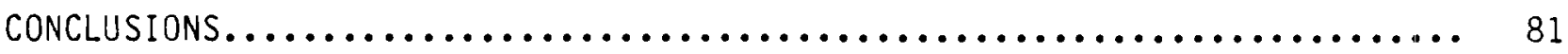

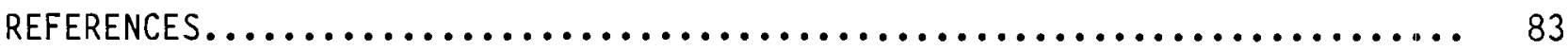




\section{FIGURES}

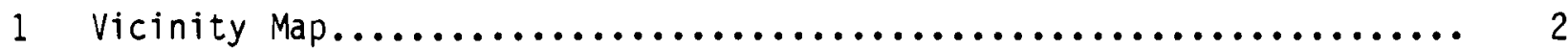

2 Mean Tide Curve, Entrance to San Franisco Bay.................. 12

3 Maximum Flood and Ebb Current Velocities...................... 13

4 Duration of Flood and Ebb Currents......................... 14

5 Significant Wave Height Versus Wind Speed for Exposed Fetches, Fort Point Station.................................... 19

6 Wave Refraction Fan Diagram, Entrance to San Francisco Bay, Wave Period of 5 Seconds................................... 24

7 Wave Refraction Fan Diagram, Entrance to San Francisco Bay, Wave Period of 10 Seconds................................. 25

8 Wave Refraction Fan Diagram, Entrance to San Franciso Bay, Wave Period of 15 Seconds................................. 26

9 Wave Refraction Fan Diagram, Entrance to San Francisco Bay, Wave Period of 20 Seconds................................. 27

10 Wave Refraction for Wave Period of 10 Seconds, Entrance to San Francisco Bay - WNW................................... 29

11 Wave Refraction for Wave Period of 10 Seconds, Entrance to San Francisco Bay - W................................ 30

12 Wave Refraction for Wave Period of 10 Seconds, Entrance to San Francisco Bay - WSW............................... 31

13 Wave Refraction for Wave Period of 10 Seconds, Entrance to

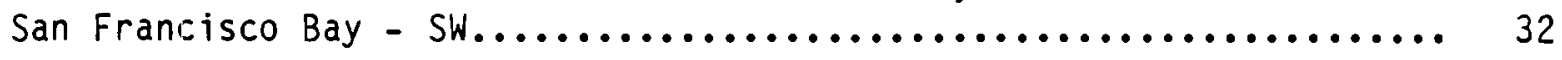

14 Wave Refraction for Wave Period of 10 Seconds, Entrance to

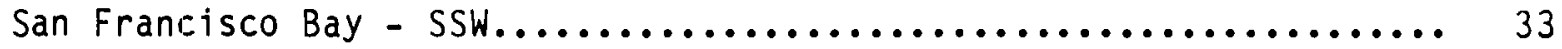

15 Wave Refraction for Wave Period of 20 Seconds, Entrance to San Francisco Bay - WNW................................ 34

16 Wave Refraction for Wave Period of 20 Seconds, Entrance to San Francisco Bay - W...................................

17 Wave Refraction for Wave Period of 20 Seconds, Entrance to San Francisco Bay - WSW. 
18 Wave Refraction for Wave Period of 20 Seconds, Entrance to

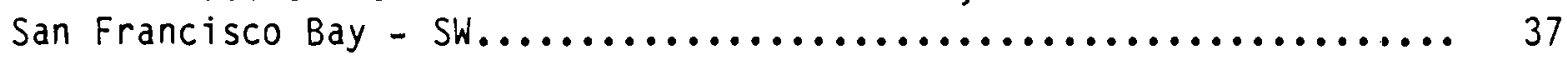

19 Wave Refraction for Wave Period of 20 Seconds, Entrance to San Francisco Bay - SSW................................ 38

20 Wave Refraction for Wave Period of 5 Seconds, Fort Point Station.... 41

21 Wave Refraction for Wave Period of 10 Seconds, Fort Point Station.... 42

22 Wave Refraction for Wave Period of 15 Seconds, Fort Point Station.... 43

23 Wave Refraction for Wave Period of 20 Seconds, Fort Point Station.... 44

24 Sediment Size Distribution, Baker Beach.................... 55

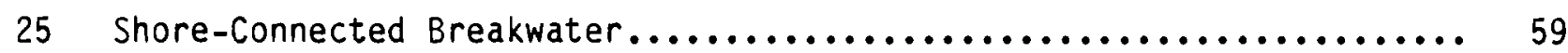

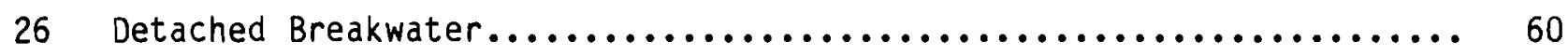

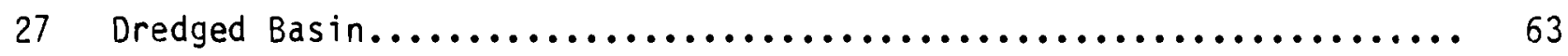




\section{$\underline{\text { TABLES }}$}

1 Percent Frequency of 0ccurrence, Wind Speed is or Exceeds Listed Value Versus wind Direction.............................. 8

2 Severe Winds at San Francisco............................. 9

3 Summary of Maximum wind Speeds.......................... 10

4 Maximum Estimated Peak Surface Wind Speeds and Return Periods....... 10

5 Fetch Characteristics, Fort Point Station.................. 17

6 Significant Wave Heights for Given Wind Speeds -

Fort Point Station...................................... 18

7 Significant Wave Periods for Given Wind Speeds -

Fort Point: Station..................................... 20

8 Annual Deepwater Wave Height Durations Due West of

San Francisco.......................................... 21

9 Significant Wave Heights for Ten Most Severe Storms Due West of San Francisco, 1951-1960............................... 22

10 Deepwater Wave Height Estimates for Specific Return Periods

off San Francisco...................................... 22

11 Wave Refraction Coefficients, Golden Gate Strait............... 30

12 Shoaling Coefficients, Golden Gate Strait..................... 39

13 Diffraction Coefficients, Fort Point Station................. 40

14 Refraction Coefficients and Breaking Wave Angles with Shoreline, Fort Point. Station................................... 45

15 Shoaling Coefficients, Fort Point Station................... 46

16 Highest Significant Wind-Generated Wave Heights at Fort Point Station............................................. 46

17 Combined Wave Refraction, Diffraction, Shoaling Coefficients, Fort Point Station for Long-Period Waves......................

18 Highest Significant Waves at Fort Point Station from Deepwater

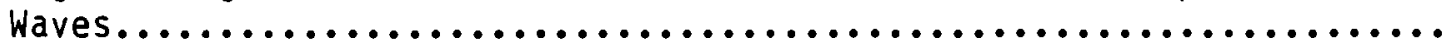

19 Longshore Sediment Transport at Fort Point Station Due to Waves...... 
20 Highest Significant Wave Heights and Other Associated Statistical Heights, Fort Point Station.................... 66

21 Wave Diffraction Coefficients - Detached Breakwater, Circular Configuration..................................... 70

22 Wave Diffraction Coefficients - Detached Breakwater, Triangular Configuration..................................... 70

23 Wave Diffraction Coefficients - Shore-Connected Breakwater......... 71

24 Diffracted Wave Heights Within Detached Breakwater, Circular

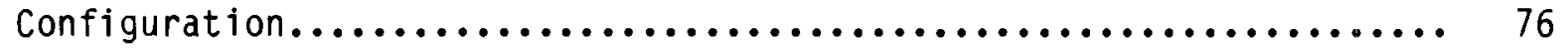

25 Diffracted Wave Heights Within Detached Breakwater, Triangular Configuration.............................. 76

26 Diffracted Wave Heights Within Shore - Connected Breakwater........ 77 
LITTORAL PROCESSES: U.S. COAST GUARD STATION

FORT POINT, SAN FRANCISCO

\section{$\underline{\text { INTRODUCTION }}$}

The U.S. Coast Guard Station, Fort Point shown in Figure 1 is located three-quarters of a nautical mile southeast of the Golden Gate Strait, the entrance to San Francisco Bay. Fort Point Station is situated on the shoreline of San Francisco Bay within the confines of the U.S. Army Presidio of San Francisco. The Station consists of shoreside support facilities, wood pile pier, and one 44-foot, one 41-foot and one 30-foot Motor Life Boats for Search and Rescue (SAR) operations. The Motor Life Boats are presently moored at the end of the pier with the use of dolphins and counter weights to hold the vessels away from the pier. An open wood pile causeway, about 340 feet in length, connects the pier to the shore. A wood sheet pile wave attenuator is positioned on the northwest side of the pier to provide some protection against the long-period ocean waves entering the Bay through the Golden Gate Strait.

The existing storm wave conditions at Fort Point Station pier make it extremely dangerous for the SAR crews to get on and off the Motor Life Boats at times requiring the vessels to be moored at the San Francisco Yacht Harbor about 1.5 miles east of the Fort point Station. In addition, it is difficult for the crews to perform routine maintenance of the Motor Life Boats because of the long-period swells entering the Bay through the Golden Gate Strait.

To mitigate these harsh working conditions the U.S. Coast Guard is considering the feasibility of constructing suitable all-weather moorings for the three Motor Life Boats at the Fort Point Station to enable unimpeded SAR operations, to provide safe working conditions for Coast Guard small boat crews, and to improve small boat maintenance conditions at Fort Point Station.

The purpose of this littoral processes investigation at Fort Point Station is to identify, analyze and evaluate physical environmental factors that could 


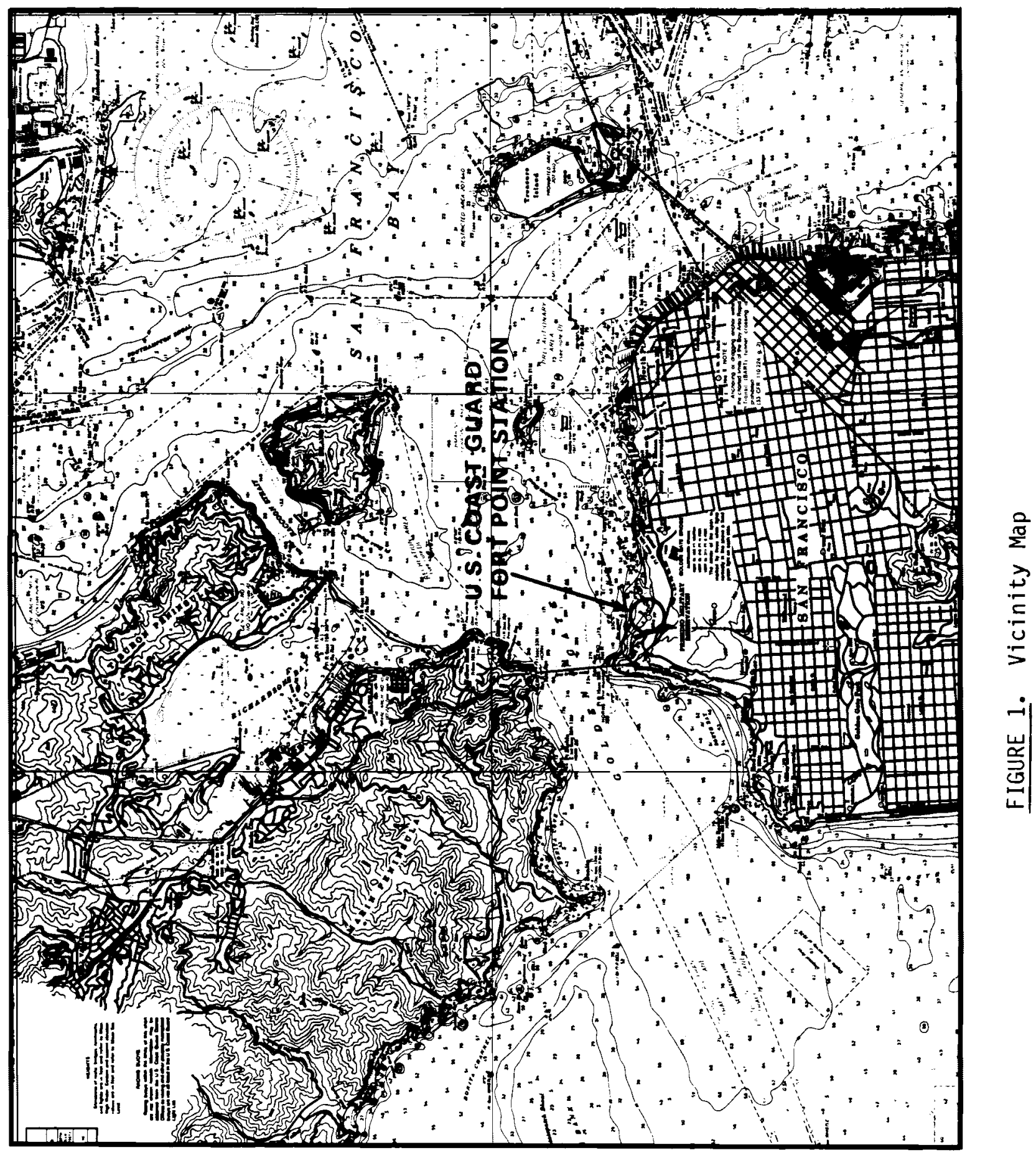


affect all-weather moorings siting, configuration and entrance location, as well as, potential post construction alterations to littoral conditions and processes.

This report includes a description of the site, description of pertinent littoral processes, evaluation of how these processes could affect construction of all-weather moorings, and discussion of design considerations, as well as mitigation measures to minimize potential adverse effects to the physical environment. 
assumed page 


\section{PHYSICAL SETTING}

As mentioned in the introduction, the U.S. Coast Guard Station, Fort Point is located about three-quarters of a nautical mile southeast of Fort Point which is the interior point at the entrance to San Francisco Bay, known as the Golden Gate Strait. The San Francisco Bay shoreline for which the Station is located is in the lee of Fort Point, protecting the shoreline from the direct impact of Pacific Ocean waves entering the Bay through the Golden Gate Strait. The shoreline in the vicinity of the Station is generally concave with direct exposure to the northeast. The San Francisco Yacht Harbor is located about 1.5 miles east of the Station.

The shoreline in the vicinity of Fort Point Station is comprised of a sandy beach from about 0.3 miles northwest of the Station pier to the beginning of the San Francisco Yacht Harbor rubble mound breakwater about one mile east of the Station pier. The backshore of the beach along its entire length is protected with riprap or concrete seawall. A concrete seawall protects the Station's shoreside facilities. The backshore protection along the beach indicates that the backshore is at times subjected to wave attack which would result in the recession of the shoreline were it not protected. The beach itself is fairly steep with the beach slope varying from 10 to 20 degrees. The beach is comprised of medium to coarse grained sand.

Historically, the reach of shoreline between the Fort Point Station and San Francisco Yacht Harbor has been subjected to extensive man-made fill which took place prior to and after the Panama-Pacific Exposition in 1915. Prior to the filling, the entire shoreline between Black Point (Fort Mason) and Fort Point was comprised of low-lying marsh and sand dunes, tidal lagoons, and intertidal and subtidal flats. The San Francisco shoreline prior to filling is shown on the 1852 Coast Survey Chart of the Entrance to San Francisco Bay (Ref 1). In preparation for the exposition tidelands were filled up to the bulkhead line along the shoreline fronting city property, and the marsh located within the Presidio of San Francisco was filled. Much of the fill material was obtained by hydraulic dredge in 30 to 50 feet of water and pumped ashore by floating pipeline. 
The Golden Gate Strait is very deep reaching depths of about 350 feet below mean lower low water (MLLW). The water shoals rapidly towards the shoreline of Golden Gate Strait. Water depths also decrease rapidly inside the entrance to San Francisco Bay. A large sand shoal, known as Alcatraz and Presidio Shoals, is present just inside the entrance and extends in a diagonal line between Alcatraz Island and Fort Point. The shoal lies at depths of between 40 and 60 feet, below MLLW. The shoal is comprised almost exclusively of fine to medium grained sand. Presidio Shoal lies directly offshore of the Fort Point Station. The water depth in the immediate vicinity of the Fort Point Station pier varies between 10 and 15 feet below MLLW. In comparison to the rest of the San Francisco portion of the Bay shoreline, the water depths directly offshore of Fort Point Station are fairly shallow. The -30 foot, MLLW contour at this location is about 2000 feet offshore. The -24-foot, MLLW contour is about 1300 feet offshore, and the -12-foot, MLLW contour is about 1000 feet offshore. 


\section{LITTORAL PROCESSES}

Littoral processes are the interactions among winds, waves, currents, tides and other phenomena in the nearshore zone, causing a shoreline to erode, accrete or remain stable. This is especially true if the shoreline consists of easily erodible sandy beach deposits such as those that occur in the vicinity of Fort Point Station. Changes occurring along a shoreline come about from the action of these external forces, and the presence or absence of beach sediment to maintain the beach or shoreline in its present form.

The configuration of a beach at any given time is at best a precarious condition subject to abrupt changes with changes in external forces (winds, waves, currents and tides) or with changes in the supply of beach material. Man-made structures placed in the nearshore zone often have an effect on littoral processes and shoreline stability in that they can cause changes in wave or current patterns, or they can interrupt the supply and transport of beach material by providing a littoral barrier. Alterations in beach stability or configuration for relatively long distances along the beach can then occur as the beach readjusts to the change in prevailing conditions. For these reasons, careful consideration should be given to littoral processes when designing a structure to be placed in the nearshore zone.

WIND

Wind is the ultimate agent responsible for generating waves which are largely responsible for shaping a beach. Table 1 is the annual summary of the frequency of occurrence of wind speeds equaling or exceeding listed values versus wind direction for Alameda Naval Air Station from 1971 through 1978 (Ref 2). Prevailing winds at in the central San Francisco Bay are from the west due to the Golden Gate Strait. These westerly winds (WNW, W, WSW) occur for about half the year. Southerly and northerly winds occur for about 20 percent of the year each, and easterly winds occur for less than 10 percent of the year. The highest average annual wind speeds are from the west and west northwest, exceeding $36 \mathrm{mph}$ for about 18 hours per year. Winds exceeding 
TABLE 1. Percent Frequency of Occurrence, Wind Speed is or Exceeds Listed Value Versus Wind Direction

Alameda, Califormia 01-01-71 through 12-31-78 Annual Average

\begin{tabular}{lcccccccccccccccccc}
\hline Speed & N & NNE & NE & ENE & E & ESE & SE & SSE & \multicolumn{3}{l}{ S } & SSW & SW & WSW & W & WW & NW & NW \\
Calm & 5.6 & 1.5 & 0.8 & 0.7 & 1.8 & 2.5 & 3.0 & 2.8 & 4.7 & 3.2 & 4.7 & 9.6 & 25.6 & 10.7 & 6.5 & 6.0 \\
1 & 5.6 & 1.5 & 0.8 & 0.7 & 1.8 & 2.5 & 3.0 & 2.8 & 4.7 & 3.2 & 4.7 & 9.6 & 25.6 & 10.7 & 6.5 & 6.0 \\
2 & 4.7 & 1.1 & 0.6 & 0.5 & 1.3 & 2.0 & 2.7 & 2.5 & 4.1 & 2.8 & 4.3 & 9.0 & 24.5 & 10.1 & 6.0 & 5.3 \\
3 & 3.2 & 0.7 & 0.4 & 0.3 & 0.5 & 1.2 & 1.9 & 1.7 & 2.6 & 1.8 & 3.1 & 7.2 & 22.0 & 8.8 & 4.7 & 4.0 \\
4 & 2.1 & 0.4 & 0.2 & 0.2 & 0.2 & 0.7 & 1.4 & 1.1 & 1.7 & 1.2 & 2.1 & 5.3 & 18.4 & 7.1 & 3.2 & 2.8 \\
5 & 1.3 & 0.2 & 0.1 & 0.1 & 0.1 & 0.4 & 1.0 & 0.8 & 1.2 & 0.7 & 1.1 & 3.4 & 13.9 & 5.2 & 2.0 & 1.7 \\
6 & 0.8 & 0.1 & 0.1 & 0 & 0 & 0.2 & 0.8 & 0.5 & 0.7 & 0.3 & 0.5 & 1.9 & 8.6 & 3.1 & 1.1 & 1.0 \\
7 & 0.6 & 0.1 & 0 & 0 & 0 & 0.1 & 0.5 & 0.4 & 0.4 & 0.1 & 0.2 & 0.9 & 4.8 & 1.6 & 0.6 & 0.6 \\
8 & 0.4 & 0 & 0 & 0 & 0 & 0.1 & 0.3 & 0.3 & 0.2 & 0.1 & 0.1 & 0.4 & 2.2 & 0.7 & 0.3 & 0.3 \\
9 & 0.2 & 0 & 0 & 0 & 0 & 0 & 0.2 & 0.2 & 0.1 & 0 & 0 & 0.1 & 0.9 & 0.3 & 0.1 & 0.2 \\
10 & 0.1 & 0 & 0 & 0 & 0 & 0 & 0.1 & 0.1 & 0.1 & 0 & 0 & 0 & 0.4 & 0.2 & 0 & 0.1 \\
11 & 0 & 0 & 0 & 0 & 0 & 0 & 0 & 0 & 0 & 0 & 0 & 0 & 0.1 & 0.1 & 0 & 0 \\
12 & 0 & 0 & 0 & 0 & 0 & 0 & 0 & 0 & 0 & 0 & 0 & 0 & 0 & 0 & 0 & 0 \\
13 & 0 & 0 & 0 & 0 & 0 & 0 & 0 & 0 & 0 & 0 & 0 & 0 & 0 & 0 & 0 & 0 \\
14 & 0 & 0 & 0 & 0 & 0 & 0 & 0 & 0 & 0 & 0 & 0 & 0 & 0 & 0 & 0 & 0 \\
15 & 0 & 0 & 0 & 0 & 0 & 0 & 0 & 0 & 0 & 0 & 0 & 0 & 0 & 0 & 0 & 0 \\
16 & 0 & 0 & 0 & 0 & 0 & 0 & 0 & 0 & 0 & 0 & 0 & 0 & 0 & 0 & 0 & 0 \\
17 & 0 & 0 & 0 & 0 & 0 & 0 & 0 & 0 & 0 & 0 & 0 & 0 & 0 & 0 & 0 & 0 \\
18 & 0 & 0 & 0 & 0 & 0 & 0 & 0 & 0 & 0 & 0 & 0 & 0 & 0 & 0 & 0 & 0 \\
19 & 0 & 0 & 0 & 0 & 0 & 0 & 0 & 0 & 0 & 0 & 0 & 0 & 0 & 0 & 0 & 0 \\
20 & 0 & 0 & 0 & 0 & 0 & 0 & 0 & 0 & 0 & 0 & 0 & 0 & 0 & 0 & 0 & 0 \\
$21-25$ & 0 & 0 & 0 & 0 & 0 & 0 & 0 & 0 & 0 & 0 & 0 & 0 & 0 & 0 & 0 & 0 \\
$25-30$ & 0 & 0 & 0 & 0 & 0 & 0 & 0 & 0 & 0 & 0 & 0 & 0 & 0 & 0 & 0 & 0 \\
$31-35$ & 0 & 0 & 0 & 0 & 0 & 0 & 0 & 0 & 0 & 0 & 0 & 0 & 0 & 0 & 0 & 0 \\
$36-40$ & 0 & 0 & 0 & 0 & 0 & 0 & 0 & 0 & 0 & 0 & 0 & 0 & 0 & 0 & 0 & 0 \\
$41-U P$ & 0 & 0 & 0 & 0 & 0 & 0 & 0 & 0 & 0 & 0 & 0 & 0 & 0 & 0 & 0 & 0
\end{tabular}


$32 \mathrm{mph}$ occur about 4 days per year from the north, southeast, south southeast, south, west northwest and north northwest. Calm conditions occur for about 40 days per year.

The wind data in Table 1 do not represent severe wind conditions since these conditions are canceled out in the averaging process in the statistical analysis. Table 2 gives the maximum recorded wind speeds (fastest one-minute wind speeds) by month and direction at San Francisco (Ref 2). The highest winds occur in the winter months and are from the southern quadrant. The winter winds are associated with large storm systems and can approach wind speeds of nearly $50 \mathrm{mph}$. Maximum winds during the spring and summer are associated with clear weather conditions. These westerly winds can reach speeds of $40 \mathrm{mph}$.

A summary of maximum wind speeds for each of the 16 compass points are shown in Table 3. These have been taken from the monthly frequency of occurrence tables (Table 1) and severe winds of record (Table 2). These wind speeds will be used to compute locally wind-generated wave heights for the exposed wave fetches at Fort Point Station in the section on waves.

Extreme wind conditions off the north central coast of California have been published by the Department of Commerce (Ref 3 ). Table 4 is a summary of their statistical estimates of maximum possible wind speeds and return periods. These maximum possible winds would be from the southwest through west quadrants and the speeds would be expected to decrease somewhat as they approach the coastline.

TIDES AND TIDAL CURRENTS

The tides of San Francisco Bay are of a semi-diurnal mixed type with two high and two low waters each day with a large diurnal inequality (i.e., the

TABLE 2. Severe Winds at San Francisco

Wind Speed MPH

\begin{tabular}{|c|c|c|c|c|c|c|c|c|c|c|c|}
\hline Jan & Feb & Mar & Apr & May & Jun & JuT & Aug & Sep & Oct & Nov & $\mathrm{Dec}$ \\
\hline $475 E$ & $47 \mathrm{SN}$ & $44 S$ & $38 \mathrm{~W}$ & $38 \mathrm{~W}$ & $40 \mathrm{~W}$ & $38 W$ & $35 \mathrm{~W}$ & $32 \mathrm{~W}$ & 43SE & 425 & $45 \mathrm{SE}$ \\
\hline
\end{tabular}


TABLE 3. Summary of Maximum Wind Speeds

\begin{tabular}{|c|c|c|}
\hline Direction & Speed & Source \\
\hline $\mathrm{N}$ & 43 & Table 1 \\
\hline NNE & 33 & Table 1 \\
\hline$N E$ & 30 & Table 1 \\
\hline ENE & 30 & Table 1 \\
\hline$E$ & 26 & Table 1 \\
\hline ESE & 33 & Table 1 \\
\hline SE & 45 & Table 2 \\
\hline SSE & 43 & Table 1 \\
\hline $\mathrm{S}$ & 47 & Table 2 \\
\hline SSW & 36 & Table 1 \\
\hline SW & 47 & Table 2 \\
\hline WSW & 33 & Table 1 \\
\hline$W$ & 43 & Table 1 \\
\hline WNW & 43 & Table 1 \\
\hline NW & 39 & Table 1 \\
\hline NNW & 39 & Table 1 \\
\hline
\end{tabular}

TABLE 4. Maximum Estimated Peak Surface Wind Speeds and Return Periods

Location

Latitude $35-40^{\circ}$

Longitude $125-130^{\circ}$

(approximately 200 miles

off central and north coasts)

\begin{tabular}{|c|c|c|c|c|}
\hline \multicolumn{5}{|c|}{$\begin{array}{l}\text { Speed (mph) } \\
\text { Return Period (yrs) }\end{array}$} \\
\hline 2 & 5 & 10 & 25 & 50 \\
\hline 70 & 81 & 86 & 94 & 101 \\
\hline
\end{tabular}

Speed (mph)

\section{TABLE 3. Summary of Maximum Wind Speeds}

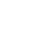


America," (Ref 4). The mean tide curve at the entrance to San Francisco Bay is shown on Figure 2. The mean higher high water level is +2.7 feet above the mean tide level and the lower low water level is 3.1 feet below the mean tide level, giving a mean tide range of 5.8 feet.

Although non-tidal and tidal currents exist in San Francisco Bay, the tidal currents are by far the most predominant in the vicinity of Fort Point Station. Tidal currents are the periodic horizontal oscillatory movement of the water accompanying the rise and fall of the tide. The tidal current regime is a mixed type with four instances of slack water and four instances of maximum velocity during two floods and two ebbs daily. The highest current strengths are attained during the period of long ebb between higher high water and lower low water of the tidal cycle. Ebb currents are somewhat increased by freshwater outflow from the Bay. Conversely, flood currents are reduced by the same force.

Information on tidal current velocities presented in Figures 3 and 4 is based upon the tidal current charts of San Francisco Bay (Ref 5). The tidal current information presented in these figures is assumed to be in a direction nearly perpendicular to the Golden Gate Bridge, approximately 0.5 miles offshore of Fort Point Station in an area where the water depth is about 52 feet below MLLW, and were based on observations of the current to a maximum depth of 20 feet. These figures depict current information under normal weather conditions. Strong winds, sudden rises in freshwater entering the Bay, etc. enhance nontidal currents which may change the speed of the currents presented. These speeds are for the time of tropic currents, that is, greater flood and ebb currents at the time of the moon's maximum declinations (Ref 5 ). It is therefore assumed that these velocities represent maximum current speeds approximately 0.5 miles offshore of Fort Point Station with a water depth of 52 feet. These currents (direction and magnitude) are assumed as being representative of the area (spacially and temporally) and do not necessarily represent actual tidal currents. Actual currents may be higher or lower than these presented.

Figure 3 presents one tidal cycle of current velocities for maximum flood and ebb tides. The time span for one cycle is about 12 hours. As figure 3 


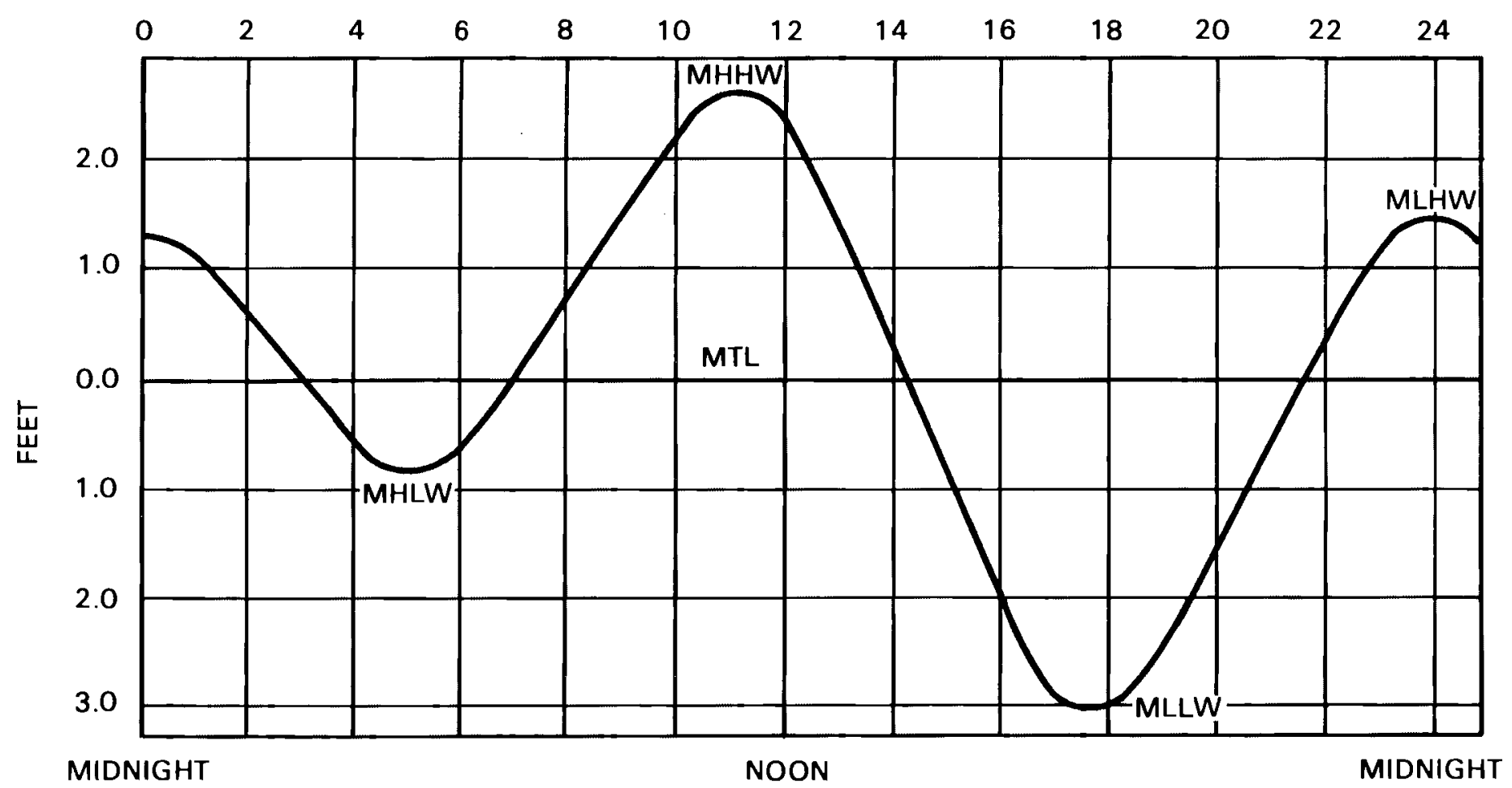

FIGURE 2. Mean Tide Curve, Entrance to San Fransisco Bay 


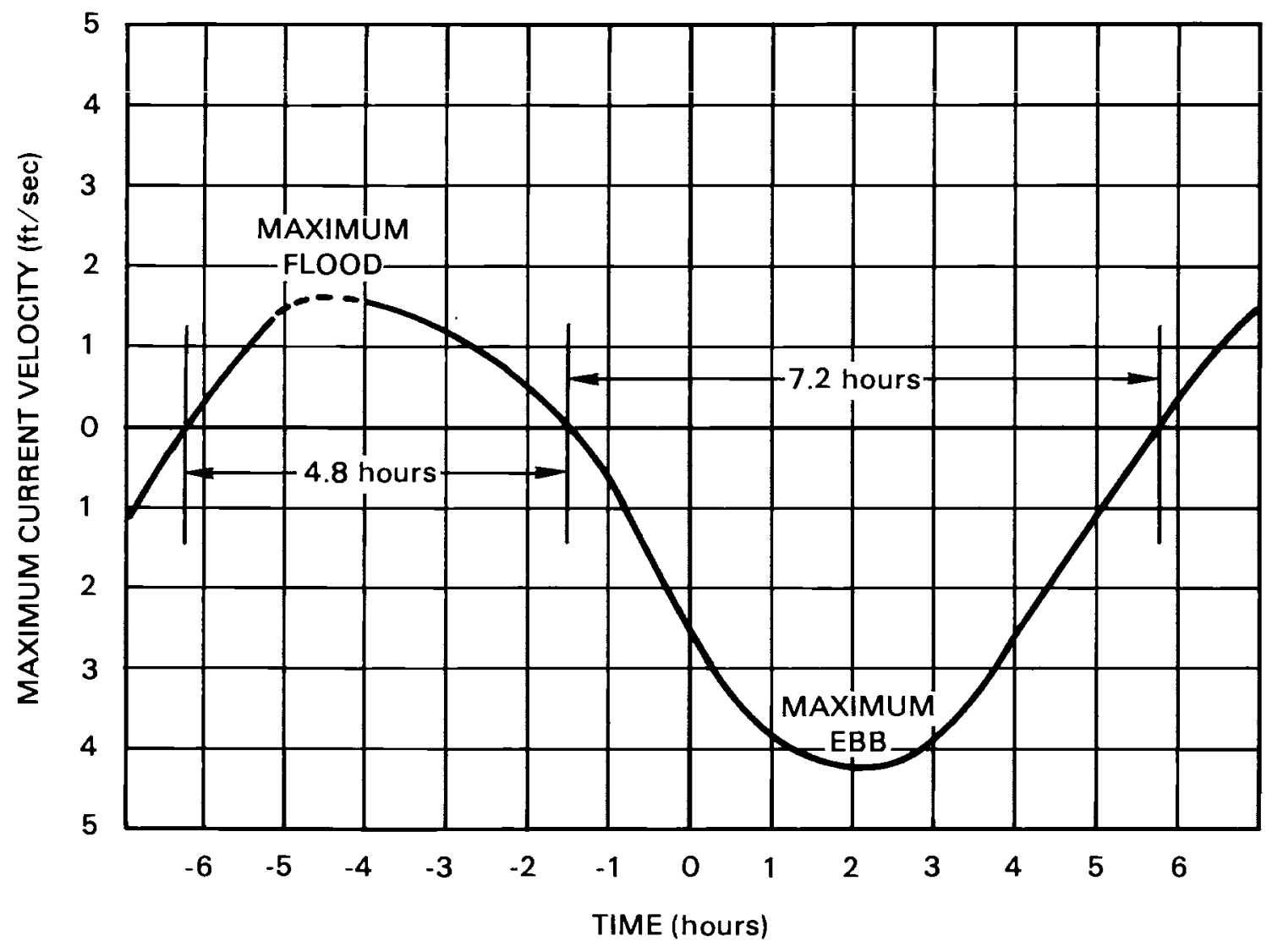

FIGURE 3. Maximum Flood and Ebb Current Velocities 


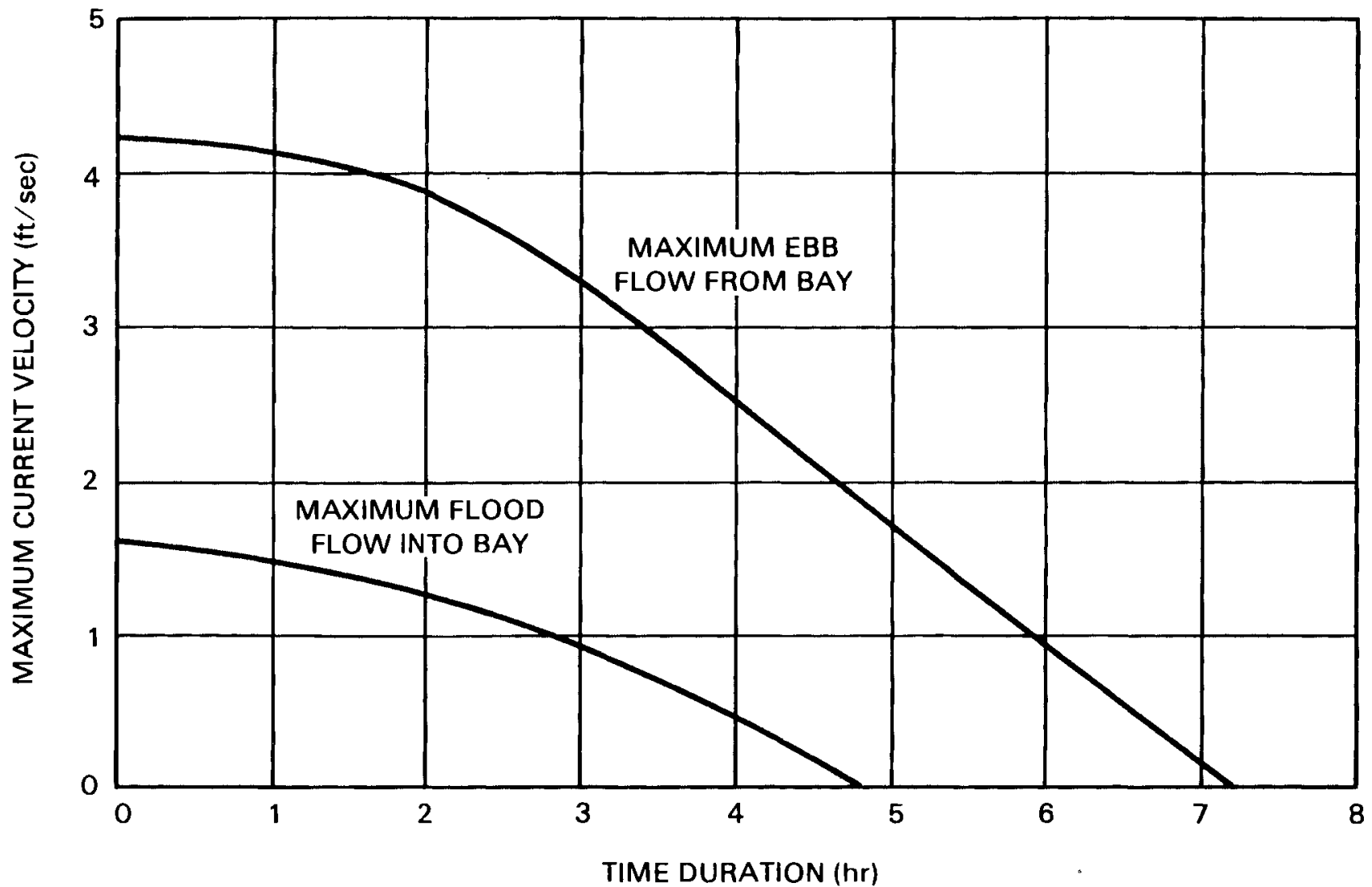

FIGURE 4. Duration of Flood and Ebb Currents 
shows, the maximum ebb tide offshore of Fort Point Station has a current velocity (i.e., $4.2 \mathrm{ft} / \mathrm{sec}$ ) larger than that of the maximum flood tide (i.e., $1.6 \mathrm{ft} / \mathrm{sec}$ ). The time duration for the maximum ebb tide (i.e., 7.2 hour) offshore of Fort Point Station is also longer than that of the flood tide (i.e., 4.8 hour).

Figure 4 presents tidal current velocity-duration levels for the maximum flood (lower curve) and ebb (upper curve) tides. These curves represent the time duration in which the tidal current velocity is equal to or larger than a given velocity. For example; at ebb tide for 3.9 hour out of a possible 7.2 hour (i.e., time duration of maximum ebb tide offshore of the Fort Point Station), the current velocity is equal to or greater than $2.6 \mathrm{ft} / \mathrm{sec}$. In effect, 54.2 percent of the time for maximum ebb tide the velocity is equal to or greater than $2.6 \mathrm{ft} / \mathrm{sec}$. The time duration of a given velocity is important in determining the amount of sediment moving due to tidal currents. A lower limit or critical velocity must be attained before sediment will be transported along the bed. If the tidal current velocities are below this critical velocity, then no sediment movement occurs. Conversely, the higher the velocities and longer their durations, the more sediment is transported by the flow.

The current velocities 0.5 miles offshore of Fort Point Station do not necessarily represent the current velocities occurring at the pier. Due to the effect of the narrow opening caused by the Golden Gate Strait, topography of the shoreline, and areas of shoaling, large current eddies or gyres tend to exist at Fort Point Station causing a reversal of flow on flood and ebb tides. (a) With a reversal of flow in this area, current velocities can be expected to be less than those measured 0.5 miles offshore in the major portion of the Bay. A reduction in current velocities and the time durations over which these velocities occur would reduce the inventory of sediment entrained and transported by the flow. In addition, the direction of the flow along the

(a) Information received from U.S. Coast Guard. 
bed during a given tidal cycle could directly affect the orientation of the entrance channel as the direction of the net sediment transport should be away from the opening of the basin.

WAVES

The Fort Point Station is subjected to both short-period waves generated in San Francisco Bay by wind, and long-period waves generated in the Pacific ocean and propagated through the Golden Gate Strait.

Wind-Generated Waves

The growth of wind waves generated within San Francisco Bay is governed by the speed and direction the wind is blowing; the duration of time the wind of a given velocity is blowing; the length of area over which the wind is blowing, known as the fetch; the width of the fetch in partially enclosed water bodies; and the depth of water across the fetch.

Fort Point Station, shown on Figure 1, is exposed to fetches from the west, through north through east southeast sectors. The fetches are extremely limited due to length and width restrictions, and in some cases depth restrictions. As a result wind-generated waves at Fort Point Station are limited in height and have short periods. Table 5 is a summary of fetch characteristics for Fort Point Station from the west, west northwest, northwest, north northwest, north, north northeast, northeast, east northeast, east and east southeast.

The effective fetch lengths at Fort Point Station are extremely short, and in all cases the growth of waves by a given wind velocity is limited by the fetch length. The longest fetches are from the nurtheast and east northeast, being respectively, 4.9 nautical miles (n.m.) and 4.5 n.m. in length. Waves generated by wind over a given fetch can also be limited in height by the depth of water if the depth is less than about one-half the wave length of the wave. The mean fetch depths for fetches from the west, northeast, east northeast, east and east southeast are small, and therefore, wave growth is limited by water depths. 
TABLE 5. Fetch Characteristics, Fort Point Station

\begin{tabular}{|c|c|c|c|}
\hline $\begin{array}{c}\text { Fetch } \\
\text { Direction }\end{array}$ & $\begin{array}{c}\text { Centroid } \\
\text { Length, n.m }\end{array}$ & $\begin{array}{l}\text { Effective } \\
\text { Length, n.m }\end{array}$ & $\begin{array}{l}\text { Mean Depth } \\
\mathrm{ft}, \mathrm{MMLLW}\end{array}$ \\
\hline W & 0.9 & 0.4 & 8 \\
\hline WNW & 2.7 & 0.9 & 122 \\
\hline$N W$ & 1.5 & 1.3 & 175 \\
\hline NNW & 1.1 & 1.7 & 245 \\
\hline$N$ & 3.6 & 2.3 & 102 \\
\hline NNE & 3.2 & 3.9 & 98 \\
\hline NE & 7.5 & 4.9 & 60 \\
\hline ENE & 7.9 & 4.5 & 35 \\
\hline$E$ & 2.0 & 3.4 & 39 \\
\hline ESE & 0.6 & 1.3 & 8 \\
\hline
\end{tabular}

Wave measurements have not been recorded at Fort Point Station. In the absence of recorded wave data, wind-generated wave characteristics must be computed. Waves generated over fetches of know lengths and depths can be computed by methods developed by Sverdrup and Munk (Ref 6), revised by Bretschneider (Ref 7), and presented in the U.S. Army Corps of Engineers "Shore Protection Manua1" (Ref 8). This wave forecasting method is based on empirical relationships developed from wind and wave observations, and has resulted in the following two equations:

$$
\begin{gathered}
H_{s}=\frac{0.283 U^{2}}{g} \tanh \left[0.530\left(\frac{g d_{m}}{u^{2}}\right)^{0.75}\right] \tanh \left\{\frac{0.125\left(\frac{g F_{\text {eff }}}{u^{2}}\right)^{0.42}}{\left[\tanh 0.530\left(\frac{g d}{u^{2}}\right)^{0.75}\right]}\right\} \\
\left.T_{S}=\frac{1.2(2 \pi U)}{g} \tanh \left[0.833\left(\frac{g d_{m}}{u^{2}}\right)^{0.375}\right] \tanh \left\{\frac{0.077\left(\frac{g F_{\text {eff }}}{U^{2}}\right)^{0.25}}{\left[\tanh 0.833\left(\frac{g d_{m}}{u^{2}}\right)^{0.375}\right.}\right]\right\}
\end{gathered}
$$


where Hs = significant wave height (feet)

$$
\begin{aligned}
U & =\text { wind velocity (feet per second) } \\
g & =\text { acceleration due to gravity }\left(32.2 \mathrm{ft} / \mathrm{sec}^{2}\right. \text { ) } \\
d_{m} & =\text { mean fetch depth (feet) } \\
F_{e f f} & =\text { effective fetch length (feet) } \\
T_{s} & =\text { significant wave period (seconds). }
\end{aligned}
$$

Table 6 and Figure 5 summarize significant wave heights at Fort Point Station for each exposed fetch direction for wind speeds from 10 to 100 miles per hour (mph). These wave heights were calculated using the effective fetch lengths and mean fetch depths shown in Table 5.

For a given wind speed the largest wind-generated waves at Fort Point Station are from the northeast and north northeast. A fifty mile per hour wind from the northeast would result in a significant wave with a height of 4.9 feet. The lowest significant wave heights at Fort Point Station generated

\begin{tabular}{|c|c|c|c|c|c|c|c|c|c|c|}
\hline \multirow{3}{*}{$\begin{array}{c}\text { Fetch } \\
\text { Direction }\end{array}$} & \multicolumn{10}{|c|}{ Significant wave Height, Feet } \\
\hline & & & & & nd $S_{p}$ & ed 1 & & & & \\
\hline & $\overline{10}$ & 20 & 30 & 40 & 50 & 60 & 70 & 80 & 90 & 100 \\
\hline W & 0.3 & 0.6 & 0.9 & 1.2 & 1.5 & 1.8 & 2.1 & 2.4 & 2.6 & 2.9 \\
\hline WNW & 0.4 & 0.9 & 1.4 & 1.9 & 2.5 & 3.1 & 3.7 & 4.3 & 4.9 & 5.6 \\
\hline NW & 0.5 & 1.0 & 1.6 & 2.3 & 2.9 & 3.6 & 4.3 & 5.0 & 5.8 & 6.5 \\
\hline NNW & 0.5 & 1.1 & 1.8 & 2.6 & 3.3 & 4.1 & 4.9 & 5.7 & 6.5 & 7.4 \\
\hline $\mathrm{N}$ & 0.6 & 1.3 & 2.1 & 2.9 & 3.7 & 4.6 & 5.5 & 6.3 & 7.2 & 8.1 \\
\hline NNE & 0.7 & 1.6 & 2.6 & 3.6 & 4.6 & 5.7 & 6.7 & 7.8 & 8.9 & 9.9 \\
\hline $\mathrm{NE}$ & 0.8 & 1.8 & 2.8 & 3.8 & 4.9 & 5.9 & 7.0 & 8.0 & 9.0 & 10.0 \\
\hline ENE & 0.7 & 1.7 & 2.6 & 3.5 & 4.4 & 5.3 & 6.1 & 7.0 & 7.7 & 8.5 \\
\hline$E$ & 0.7 & 1.5 & 2.3 & 3.2 & 4.1 & 4.9 & 5.8 & 6.6 & 7.4 & 8.2 \\
\hline ESE & 0.4 & 0.9 & 1.3 & 1.7 & 2.1 & 2.4 & 2.6 & 2.9 & 3.1 & 3.3 \\
\hline
\end{tabular}
by a given wind velocity are from the west and east southeast due to the partial protection of the shoreline. Fifty mile per hour winds from the west would generate waves with a significant height of only 1.5 feet.

TABLE 6. Significant Wave Heights for Given wind Speeds - Fort Point Station 


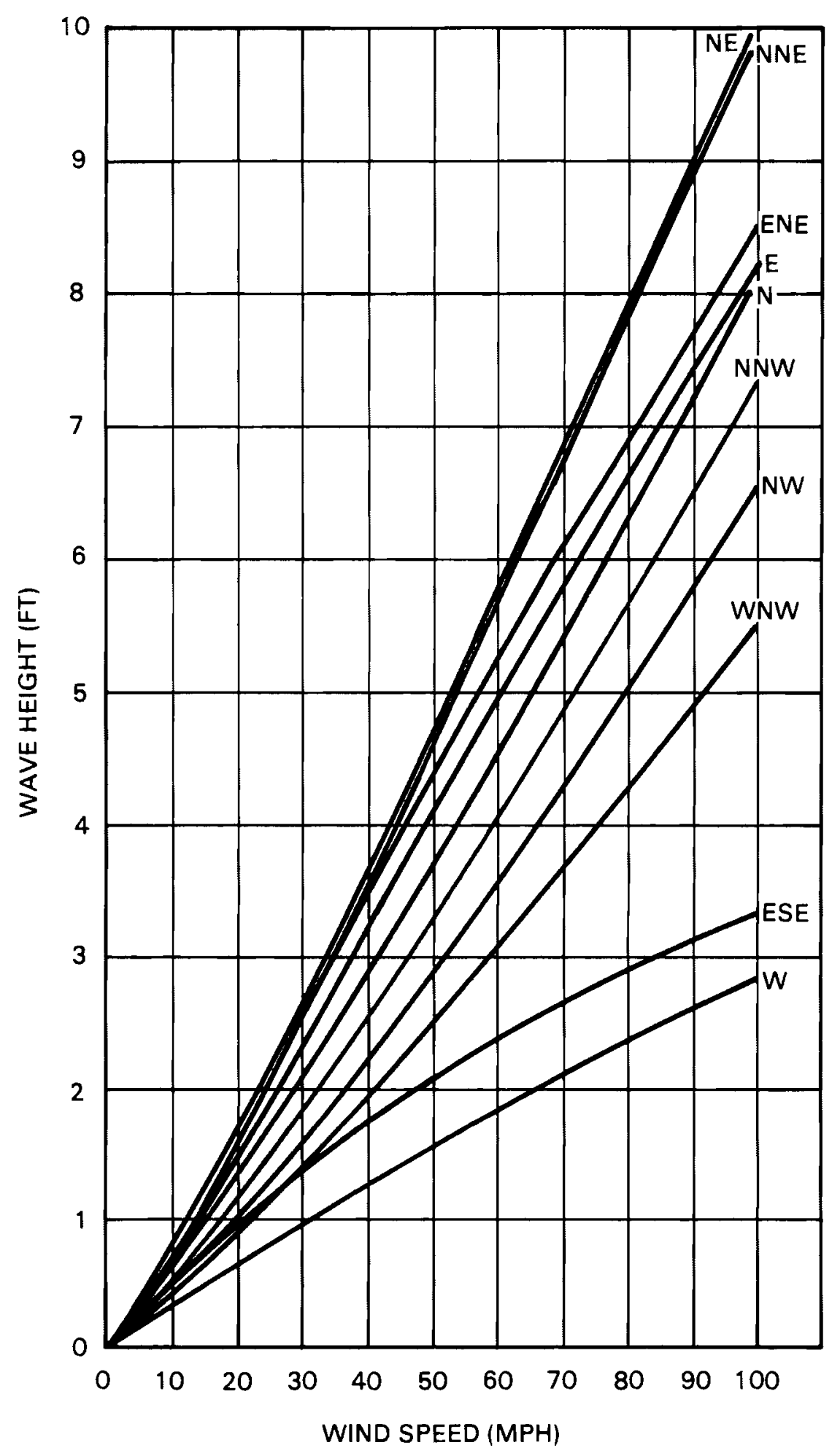

FIGURE 5. Significant Wave Height Versus Wind Speed for Exposed Fetches, Fort Point Station 
Table 7 is a summary of significant wave periods associated with the wave heights given in Table 6 . The wind-generated waves have short periods, varying between 2 and 6 seconds. The longer wave periods are associated with higher wind speeds and longer effective fetch lengths.

Long-Period Waves

Deepwater waves generated in the Pacific Ocean are propagated towards the coast and transmitted into San Francisco Bay through the Golden Gate Strait. The characteristics of these long-period waves are vastly altered by shoaling and refraction as they are propagated across San Francisco Bar, and by refraction and diffraction as the waves are transmitted into San Francisco Bay. The wave characteristics can also be altered to some degree by tidal currents emanating from the Bay through Golden Gate Strait. By the time the long-period waves reach Fort Point Station the wave height has generally decreased, the wave length has shortened, and the direction of wave travel has been altered. The wave period may also decrease during ebb tide at the Golden Gate Strait.

Statistical deepwater wave conditions along the coast of California have been described by National Marine Consultants (Ref 9 ). Table 8 is an annual

TABLE 7. Significant Wave Periods for Given Wind Speeds - Fort Point Station Significant Wave Height, Seconds

\begin{tabular}{|c|c|c|c|c|c|c|c|c|c|c|}
\hline \multirow{2}{*}{$\begin{array}{c}\text { Fetch } \\
\text { Direction }\end{array}$} & \multicolumn{10}{|c|}{ Wind Speed $(\mathrm{mph})$} \\
\hline & 10 & 20 & 30 & 40 & 50 & 60 & 70 & 80 & 90 & 100 \\
\hline W & 1.1 & 1.5 & 1.8 & 2.1 & 2.3 & 2.5 & 2.7 & 2.9 & 3.0 & 3.2 \\
\hline WNW & 1.3 & 1.9 & 2.4 & 2.7 & 3.1 & 3.3 & 3.6 & 3.9 & 4.1 & 4.3 \\
\hline NW & 1.4 & 2.1 & 2.6 & 3.0 & 3.4 & 3.7 & 4.0 & 4.2 & 4.5 & 4.7 \\
\hline NNW & 1.5 & 2.2 & 2.8 & 3.2 & 3.6 & 3.9 & 4.3 & 4.5 & 4.8 & 5.1 \\
\hline N & 1.6 & 2.4 & 3.0 & 3.4 & 3.8 & 4.2 & 4.5 & 4.8 & 5.1 & 5.3 \\
\hline NNE & 1.8 & 2.7 & 3.3 & 3.8 & 4.3 & 4.7 & 5.0 & 5.4 & 5.7 & 6.0 \\
\hline NE & 1.9 & 2.8 & 3.4 & 4.0 & 4.4 & 4.8 & 5.3 & 5.5 & 5.8 & 6.1 \\
\hline ENE & 1.8 & 2.7 & 3.3 & 3.8 & 4.2 & 4.5 & 4.9 & 5.2 & 5.5 & 5.7 \\
\hline$E$ & 1.8 & 2.5 & 3.1 & 3.6 & 4.0 & 4.3 & 4.7 & 5.0 & 5.2 & 5.5 \\
\hline ESE & 1.4 & 1.9 & 2.3 & 2.6 & 2.9 & 3.1 & 3.3 & 3.5 & 3.7 & 3.9 \\
\hline
\end{tabular}


TABLE 8. Annual Deepwater Wave Height Durations (Hours) Due West of San Francisco

\begin{tabular}{|c|c|c|c|c|c|c|c|c|c|c|c|}
\hline Wave & \multicolumn{11}{|c|}{ Direction } \\
\hline Height & $\underline{\mathrm{N}}$ & NNW & $\mathrm{NW}$ & WNW & $W$ & WSW & SW & SSW & $S$ & SSE & TOTAL \\
\hline $1-2.9$ & 1 & 177 & 1546 & 755 & 482 & 121 & 151 & 9 & 92 & 50 & 3384 \\
\hline $3-4.9$ & 2 & 184 & 1160 & 664 & 457 & 92 & 83 & 32 & 88 & 36 & 2798 \\
\hline $5-6.9$ & 1 & 71 & 392 & 290 & 185 & 36 & 18 & 10 & 21 & 11 & 1035 \\
\hline $7-8.9$ & & 66 & 339 & 124 & 80 & 21 & 19 & 13 & 43 & 21 & 726 \\
\hline $9-10.9$ & & 24 & 101 & 35 & 32 & 8 & 3 & 5 & 8 & 8 & 224 \\
\hline $11-12.9$ & & 21 & 40 & 15 & 32 & 11 & 1 & 4 & 11 & 1 & 136 \\
\hline $13-14.9$ & & & 25 & 9 & 8 & 1 & 2 & 6 & 9 & 4 & 64 \\
\hline $15-16.9$ & & 4 & 8 & 5 & 7 & 3 & & 2 & 2 & 1 & 32 \\
\hline $17-18.9$ & & & 3 & 1 & 5 & 2 & & & 1 & & 12 \\
\hline $19-20.9$ & & & & 1 & 4 & 1 & & & & & 6 \\
\hline $21-22.9$ & & & & & & & & & & & - \\
\hline $23-24.9$ & - & & & & 4 & & & 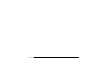 & 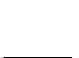 & & 4 \\
\hline TOTAL & 4 & 547 & 3614 & 1899 & 1296 & 296 & 277 & 81 & 275 & 132 & 8421 \\
\hline
\end{tabular}

Source: National Marine Consultants, 1960

summary of combined deepwater sea and swell conditions at the National Marine Consultants Station 3 due west of San Francisco. Prevailing deepwater wave direction is from the northwest for both seas and swells. Swells from the west through north northwest occur on an average of about 339 days during the year. Swells from the west southwest through south occur for only about 26 days during the year. Seas are somewhat more variable, mainly because these waves are generated by local storms. However, seas from the west through north northwest occur for about 207 days during the year.

Based on Table 8, predominant wave heights are from 1 to 7 feet. Wave heights From 7 to 12.9 feet occur for about 45 days during the year. Wave heights from 13 feet to 18.9 feet occur for about 5 days during the year and wave heights in excess of 19 feet can be expected for about one day during the year. 
National Marine Consultants also computed significant deepwater wave heights for the ten most severe storms between 1951 and 1960 at Station 3, due west of San Francisco (Ref 10). Table 9 is a summary of these wave heights. Quayle and Fishbright (Ref 11) calculated the highest significant and maximum wave heights for specific return periods. These are summarized in Table 10. For the period of 1951 to 1960 the highest significant wave height hindcasted by National Marine Consultants occurred in February 1960 with a height of

TABLE 9. Significant Wave Heights for Ten Most Severe Storms Due West of San Francisco, 1951-1960

\begin{tabular}{|c|c|c|c|}
\hline Date & $H_{S}$ & $T_{s}$ & Dir \\
\hline & & & \\
\hline Dec 51951 & 18 & 10 & WNW \\
\hline Dec 71952 & 16 & 10 & SW \\
\hline Jan 101953 & 20 & 12 & WSW \\
\hline Feb 131954 & 18 & 11 & $W$ \\
\hline Mar 41956 & 15 & 14 & WNW \\
\hline Feb 21958 & 18 & 10 & SSE \\
\hline Apr 21958 & 26 & 13 & WNW \\
\hline Nov 141958 & 20 & 13 & NW \\
\hline Feb 161959 & 20 & 10 & $S$ \\
\hline Feb 91960 & 33 & 13 & $W(280)$ \\
\hline
\end{tabular}

Source: National Marine Consultants

TABLE 10. Deepwater Wave Height Estimates for Specific Return Periods off San Francisco

\begin{tabular}{|c|c|c|}
\hline $\begin{array}{l}\text { Return } \\
\text { Period } \\
\text { yrs } \\
\end{array}$ & $\begin{array}{c}\text { Signif Wave } \\
\text { Height } \\
\mathrm{ft} \\
\end{array}$ & $\begin{array}{c}\text { Extreme } \\
\text { Wave Height } \\
\mathrm{ft}\end{array}$ \\
\hline 5 & 38 & 68 \\
\hline 10 & 43 & 77 \\
\hline 25 & 50 & 90 \\
\hline 50 & 56 & 101 \\
\hline 100 & 63 & 113 \\
\hline
\end{tabular}


33 feet. According to Quayle and Fishbright the return period for a significant height of 33 feet off of San Francisco is slightly less than 5 years. Wave Refraction Across San Francisco Bar

Wave refraction is the process by which the direction of travel of a wave moving into shallow water is altered due to the differential change in velocity along the crest of the wave. When the wave approaches the shoreline at an angle to the depth contours, that part of the wave advancing in shallower water moves more slowly than that part still advancing in deeper water, causing the wave crest to bend towards an alignment with the bottom contours. Wave refraction, coupled with shoaling determines the wave height at any given location for a given set of incident deepwater wave conditions. Refraction, therefore, has a significant influence on the wave height and distribution of wave energy along the coast.

Golden Gate Strait, at a point adjacent to Fort Point, is directly exposed to deepwater waves from the west through southwest. Wave refraction across San Francisco Bar, however, increases the exposure to waves from the west northwest and south southwest. Figures $6,7,8$, and 9 are wave refraction fan diagrams for wave periods of $5,10,15$ and 20 seconds advancing from deepwater into Golden Gate Strait. The radiating lines in the figures represent wave orthagonals, lines drawn perpendicular to the wave crests. The fan diagrams show the effects of San Francisco Bar on waves of different periods and directions as they advance across the bar and into Golden Gate Strait. The wave refraction or bending of waves entering Golden Gate Strait increases with increasing wave period as indicated on the wave refraction fan diagrams. This phenomena is due to the fact that longer-period waves are affected by the bottom at deeper depths than the shorter-period waves, and therefore, refraction occurs over relatively longer distances.

Deepwater waves from a given direction and period entering Golden Gate Strait will be refracted in such a way that the wave heights will be less than the incident deepwater wave heights. The decrease in wave heights is due to the deep water of Golden Gate Strait which will cause the wave orthagonals to diverge, decreasing the wave energy, and thus, the wave height. Wave 


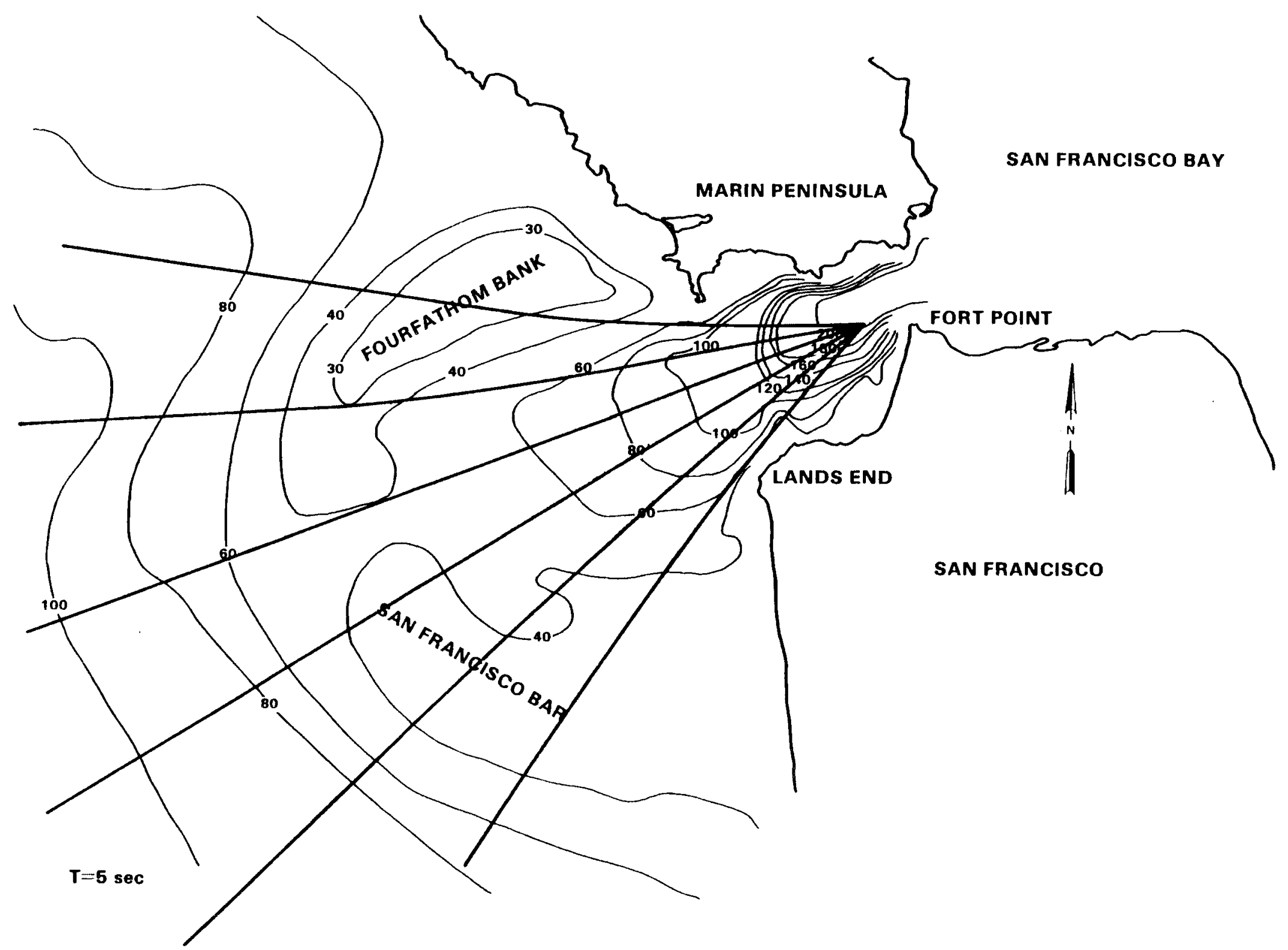

FIGURE 6. Wave Refraction Fan Diagram, Entrance to San Fransisco Bay, Wave Period of 5 Seconds 


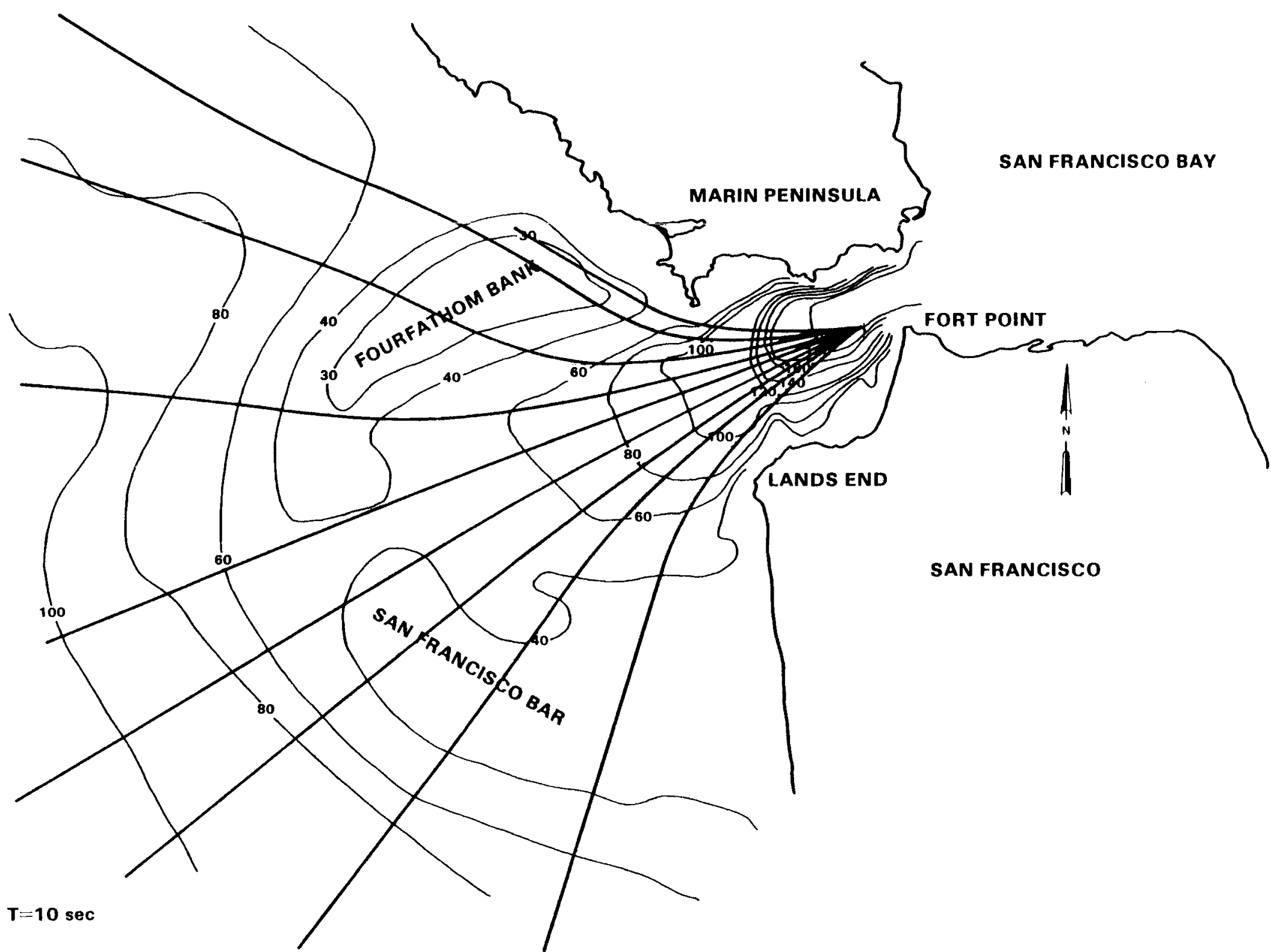

FIGURE 7. Wave Refraction Fan Diagram, Entrance to San Fransisco Bay, Wave Period of 10 Seconds 


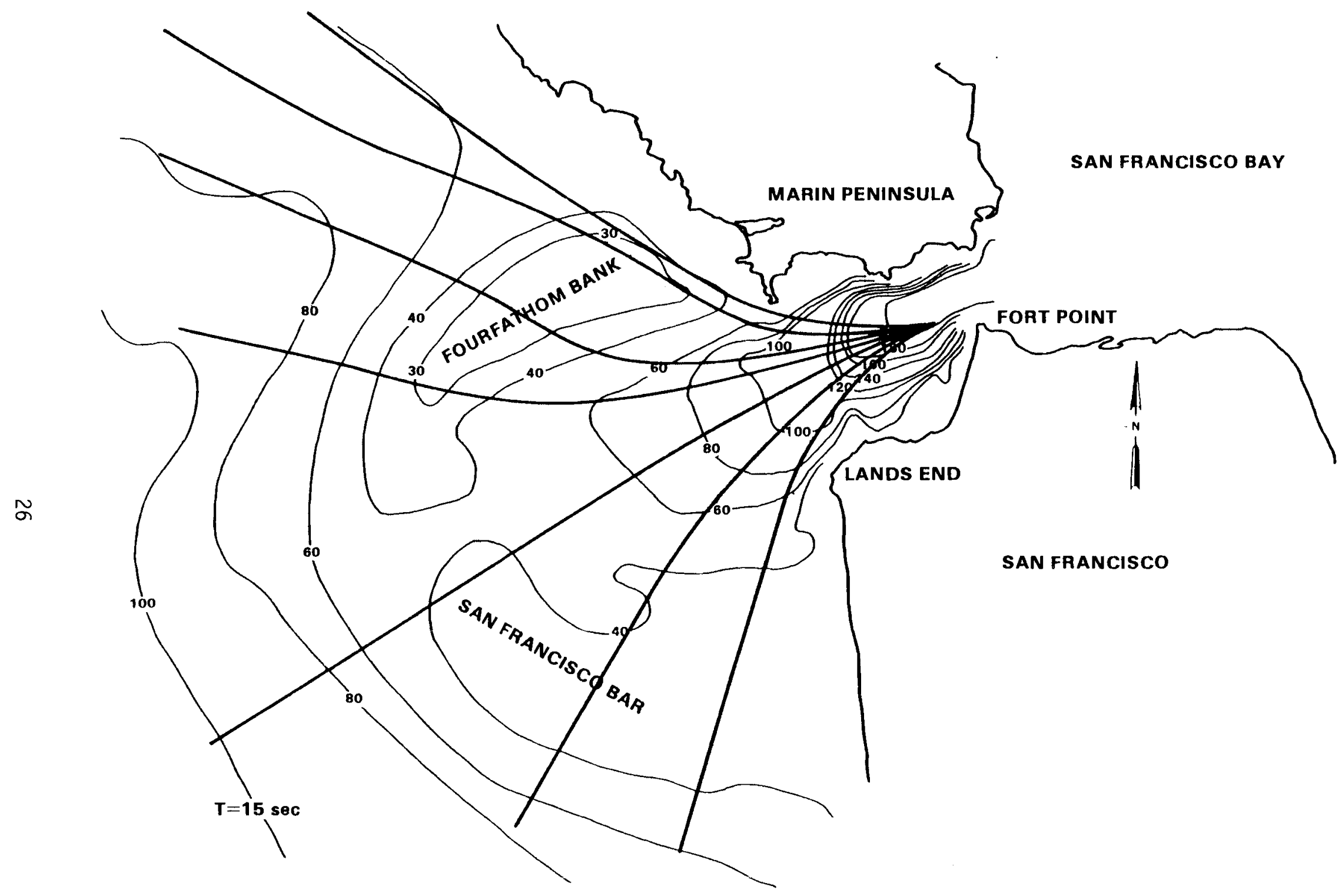

FIGURE 8. Wave Refraction Fan Diagram, Entrance to San Franciso Bay, Wave Period of 15 Seconds 


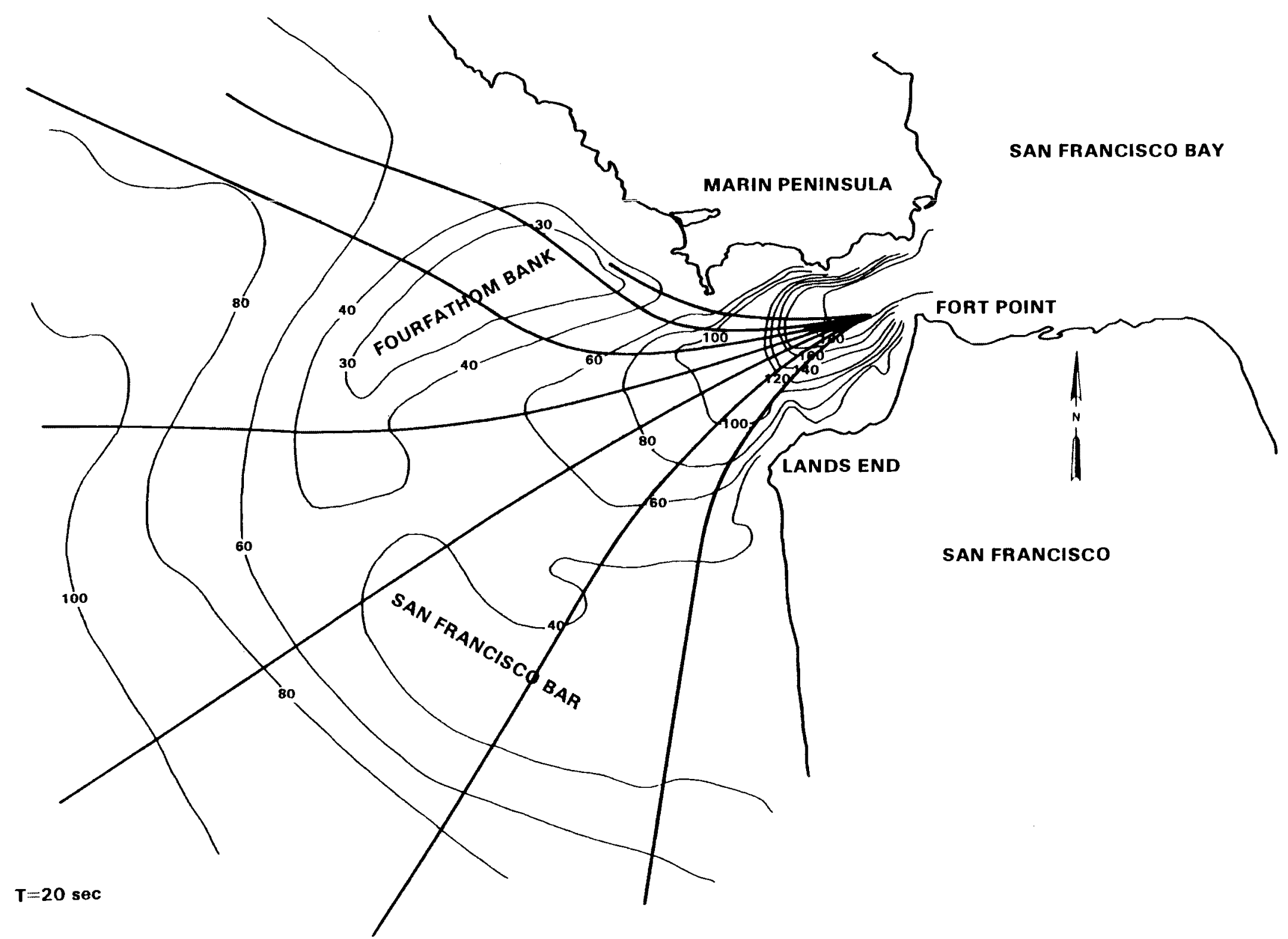

FIGURE 9. Wave Refraction Fan Diagram, Entrance to San Francisco Bay, Wave Period of 20 Seconds 
refraction diagrams in Figures 10 through 19 demonstrate the divergence of deepwater waves with periods of 10 and 20 seconds for each of the exposed deepwater wave fetches. The refraction coefficients for the wave periods of 5 , 10, 15 and 20 seconds for the exposed deepwater wave fetches at a point in Golden Gate Strait adjacent to Fort Point are shown in Table 11. The refraction coefficient is defined as the square root of the ratio of the spacing between adjacent orthagonals in deep water and in shallow water at a given point, in this case in Golden Gate Strait. When multiplied by the shoaling factor, this becomes the wave height coefficient or the ratio of the refracted wave height at a given point to the deepwater wave height:

$$
\begin{aligned}
& K_{R}=\left(\frac{b_{0}}{b}\right)^{1 / 2} \\
& H=K_{R} K_{S} H_{0}
\end{aligned}
$$

where

$$
\begin{aligned}
K_{R} & =\text { refraction coefficient } \\
K_{S} & =\text { shoaling coefficient } \\
b_{0} & =\text { spacing of orthagonal in deep water } \\
b & =\text { spacing in orthagonal in shallow water } \\
H_{0} & =\text { Deepwater wave height } \\
H & =\text { wave height in shallow water }
\end{aligned}
$$

\begin{tabular}{|c|c|c|c|c|}
\hline Direction & $T=5 \mathrm{sec}$ & $I=10 \mathrm{sec}$ & $T=15 \mathrm{sec}$ & $T=20 \mathrm{sec}$ \\
\hline WNW & - & 0.83 & 0.60 & 0.53 \\
\hline$W$ & 0.73 & 0.45 & 0.47 & 0.37 \\
\hline WSW & 0.91 & 0.71 & 0.65 & 0.57 \\
\hline SW & 0.98 & 0.69 & 0.69 & 0.60 \\
\hline SSW & - & 0.52 & 0.53 & 0.62 \\
\hline
\end{tabular}

TABLE 11. Wave Refraction Coefficients, Golden Gate Strait 


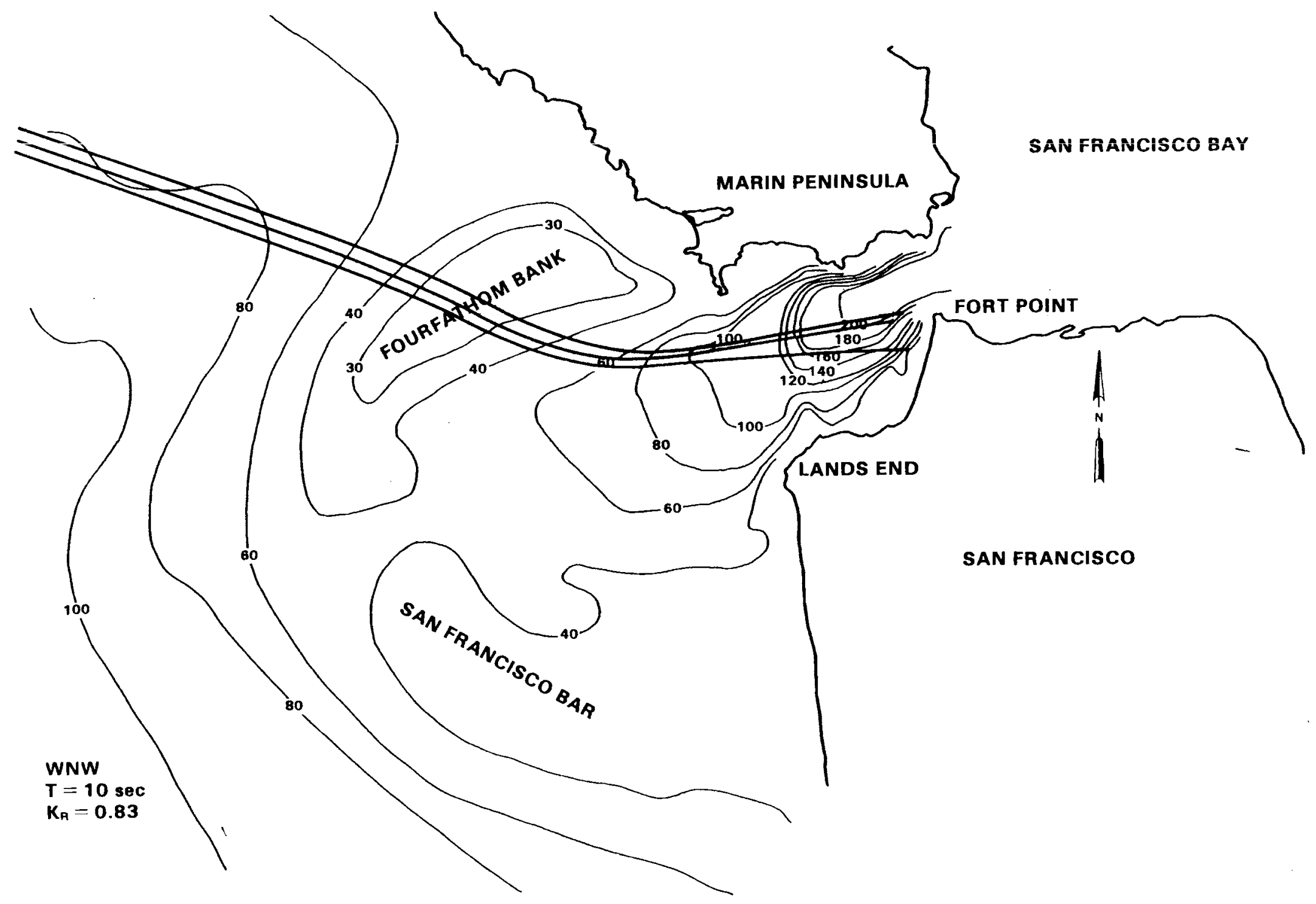

FIGURE 10. Wave Refraction for Wave Period of 10 Seconds, Entrance to San Francisco Bay - WNW 


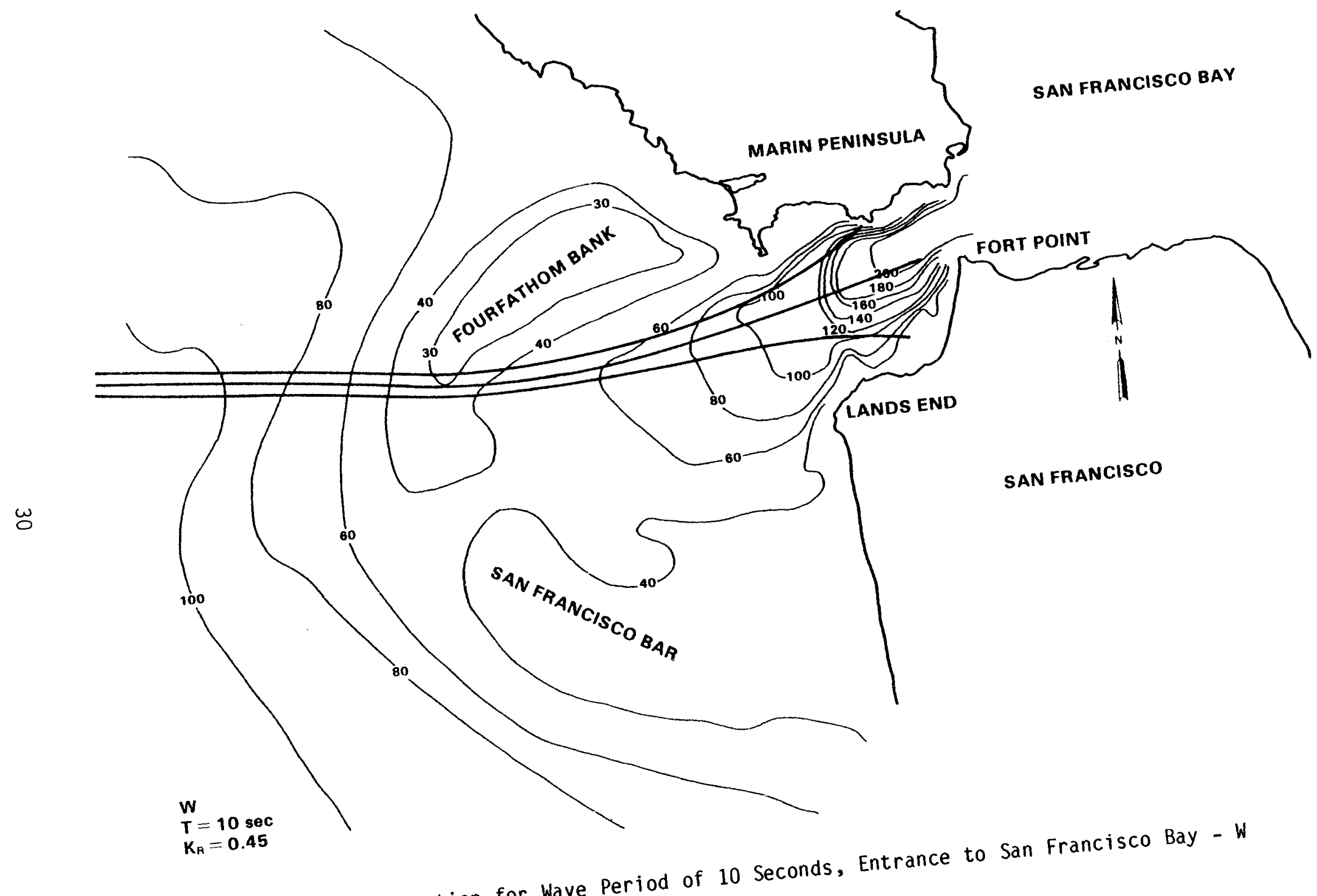

FIGURE 11. Wave Refraction for Wave Period of 10 Seconds, Entrance to san 


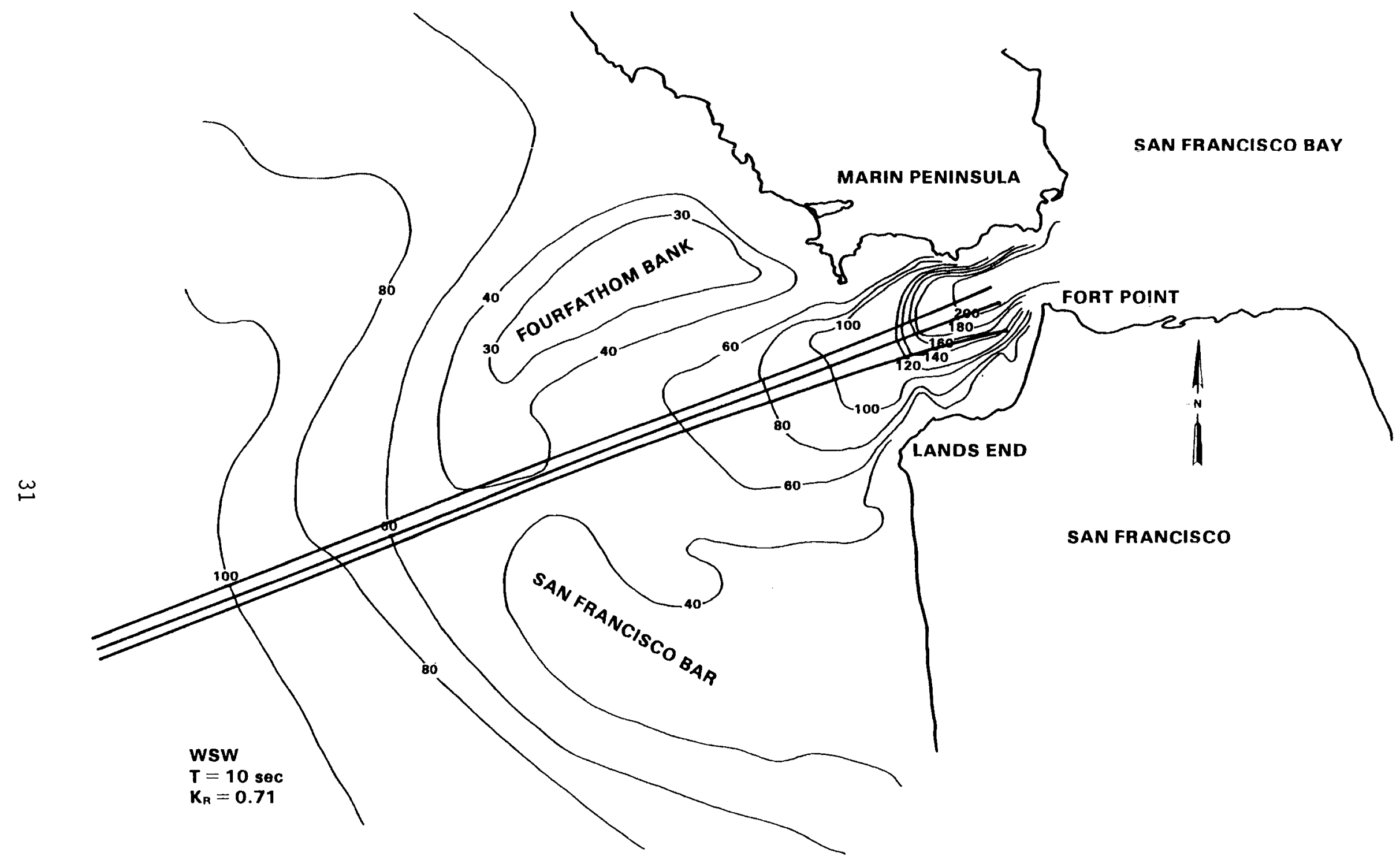

FIGURE 12. Wave Refraction for Wave Period of 10 Seconds, Entrance to San Francisco Bay - WSW 


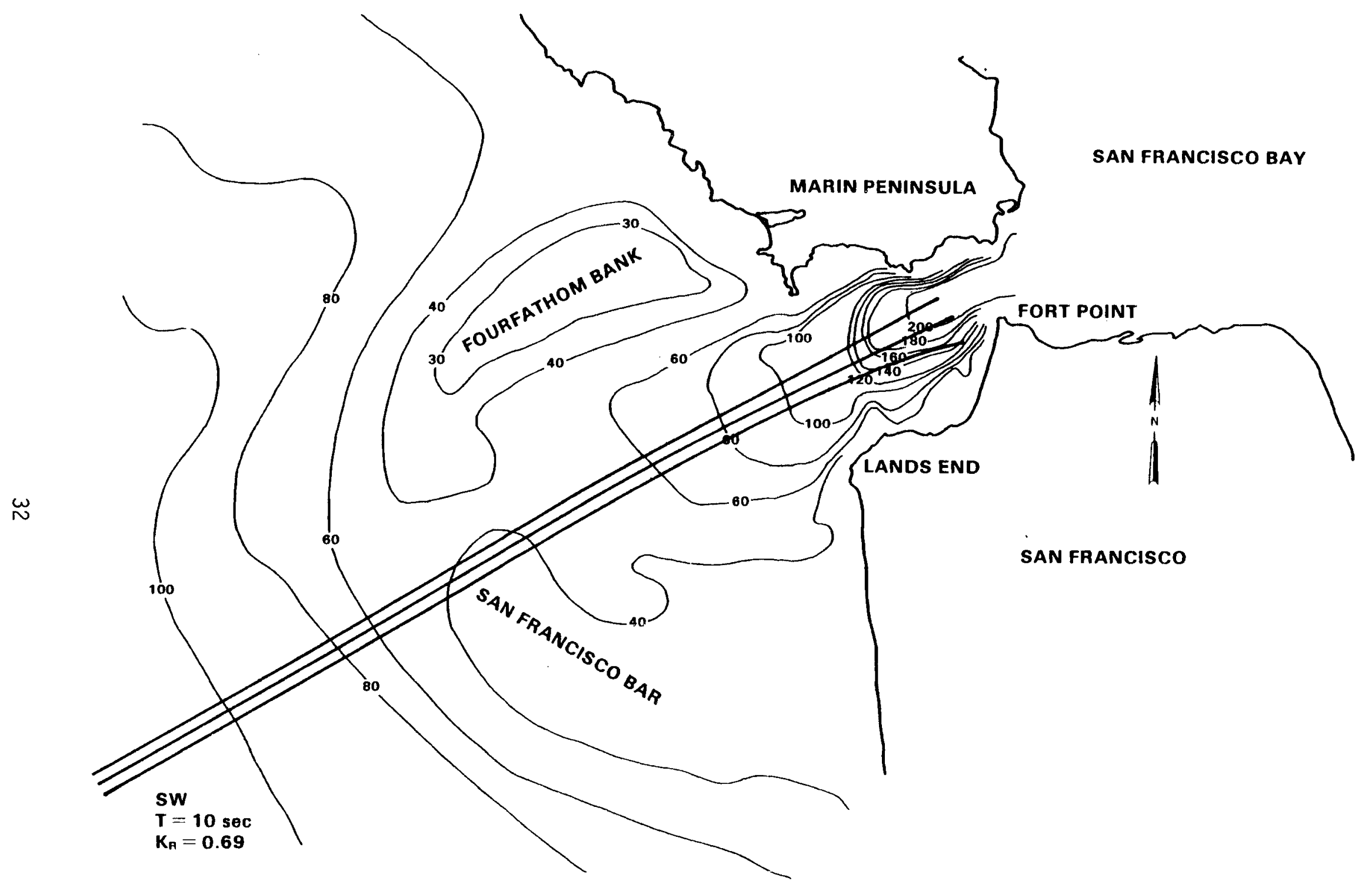

FIGURE 13. Wave Refraction for Wave Period of 10 Seconds, Entrance to San Francisco Bay - SW 


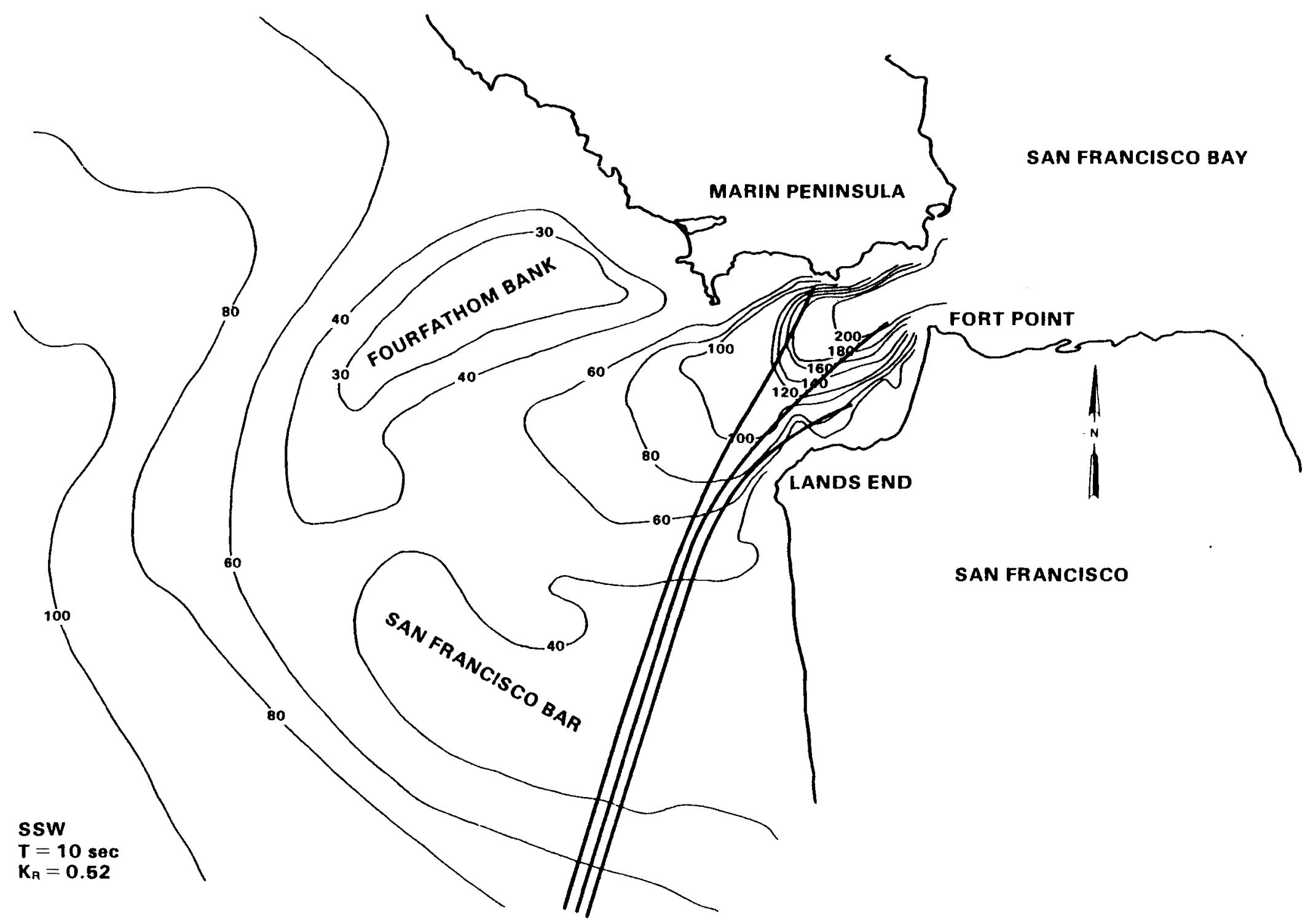

FIGURE 14. Wave Refraction for Wave Period of 10 Seconds, Entrance to San Francisco Bay - SSW 


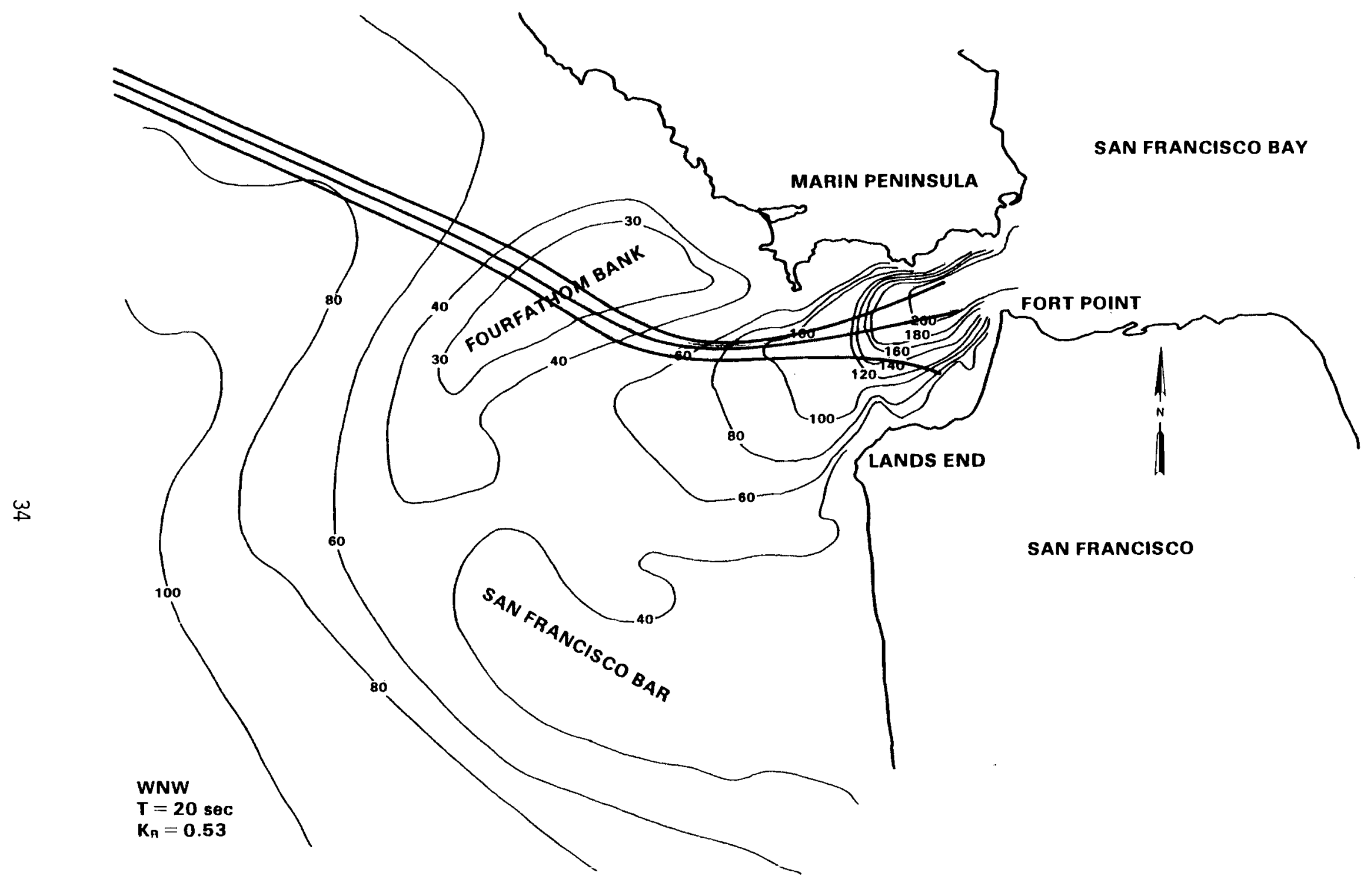

FIGURE 15. Wave Refraction for Wave Period of 20 Seconds, Entrance to San Francisco Bay - WNW 


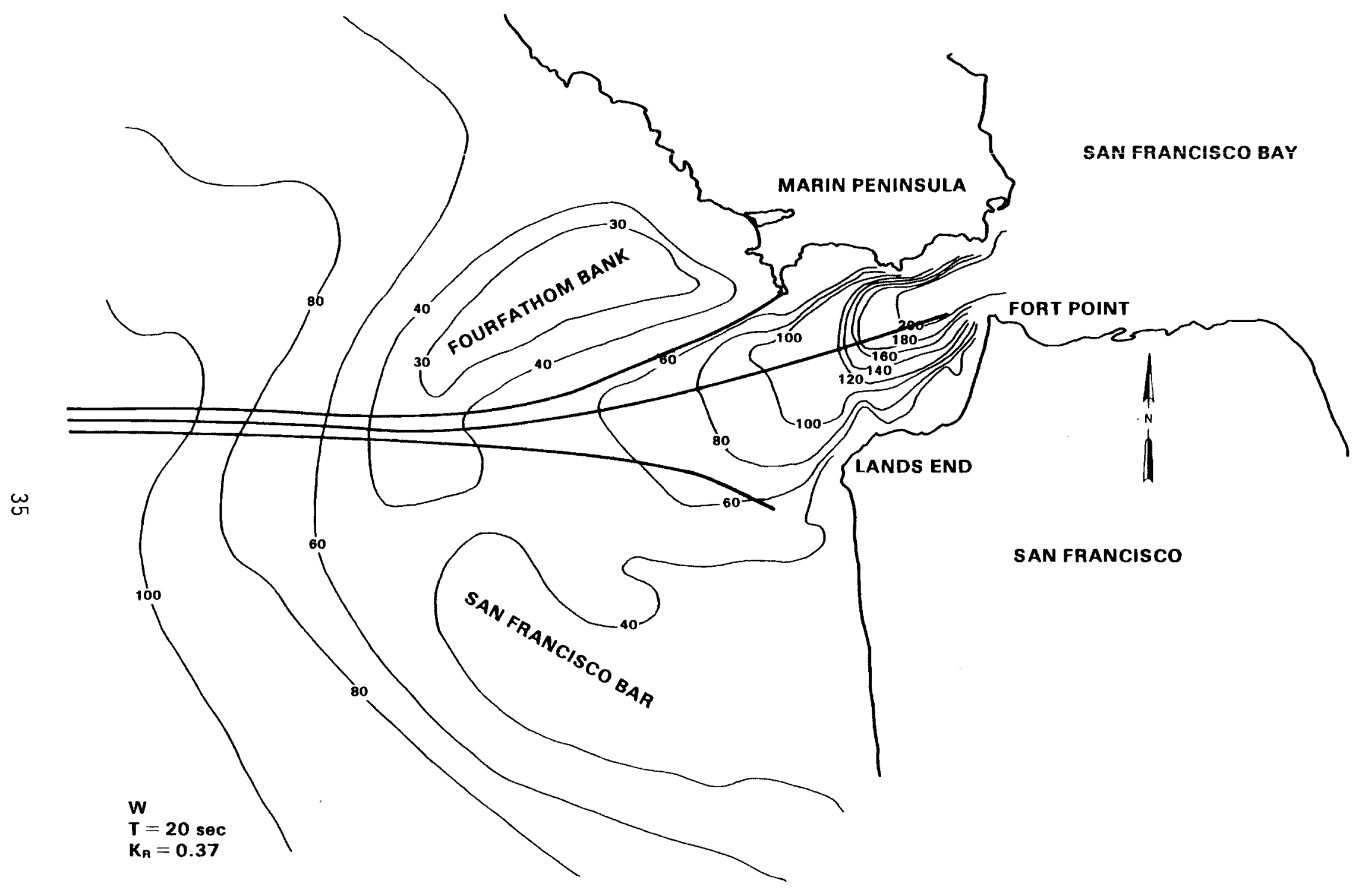

FIGURE 16. Wave Refraction for Wave Period of 20 Seconds, Entrance to San Francisco Bay - W 


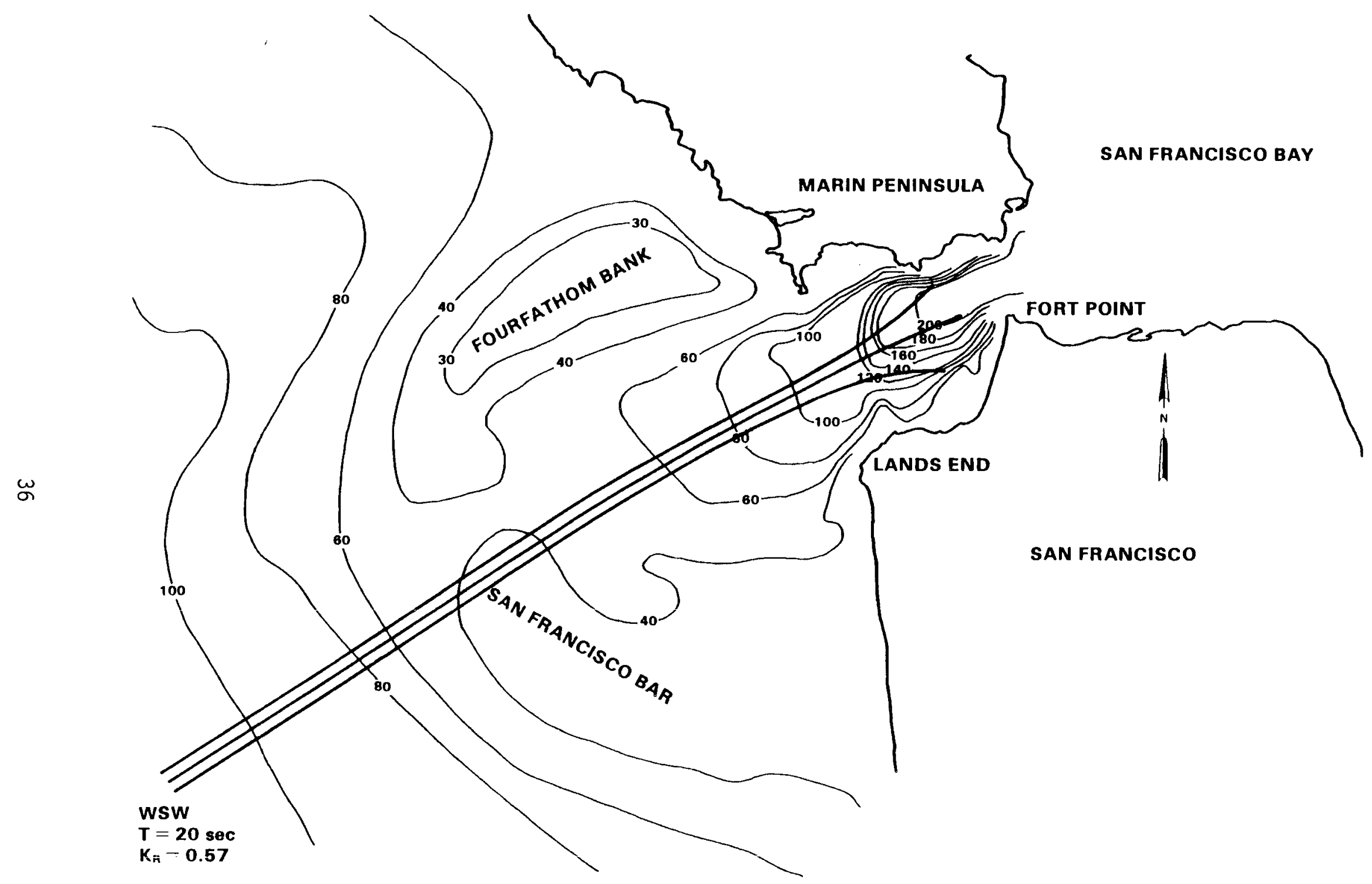

FIGURE 17. Wave Refraction for Wave Period of 20 Seconds, Entrance to San Francisco Bay - WSW 


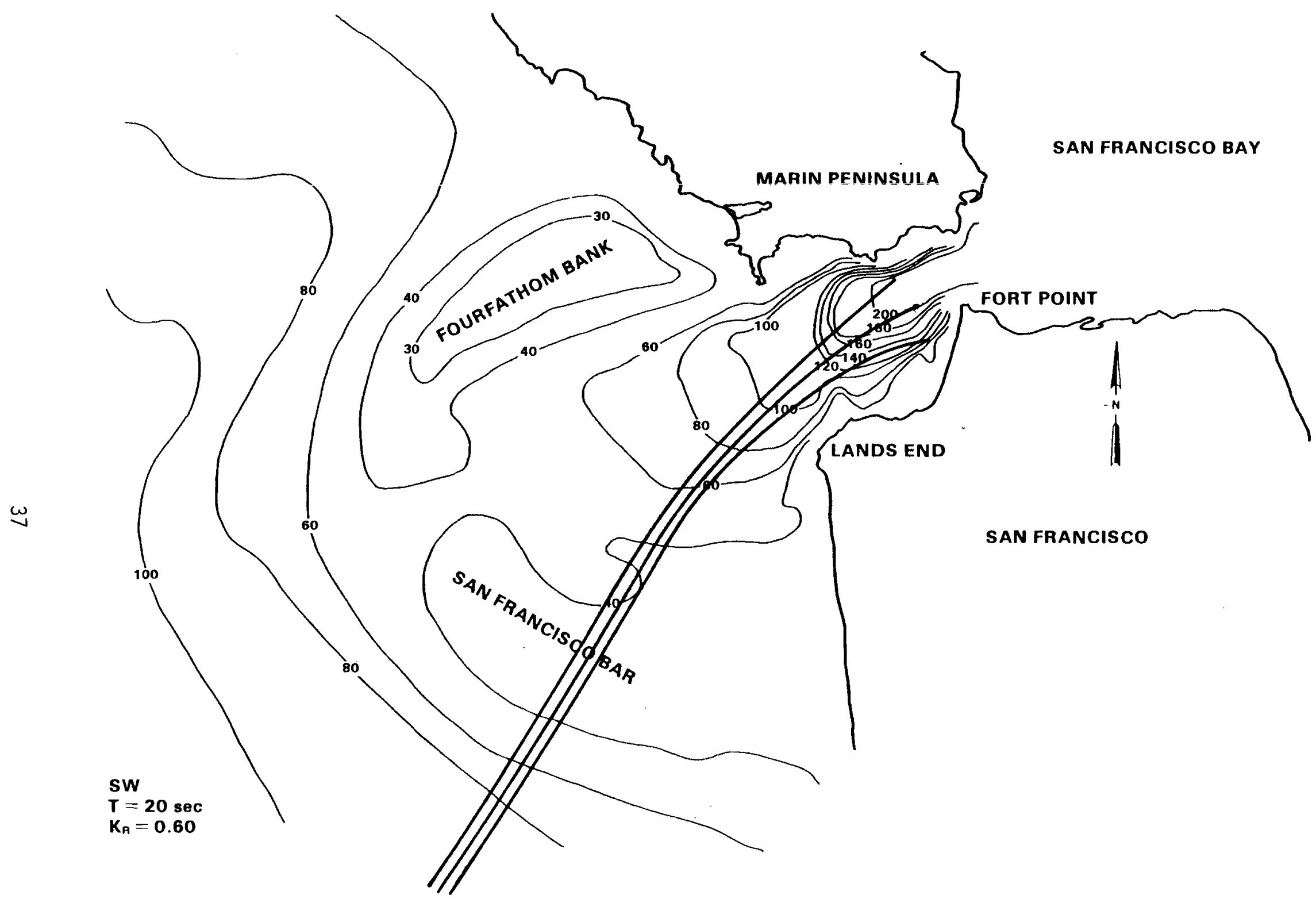

FIGURE 18. Wave Refraction for Wave Period of 20 Seconds, Entrance to San Francisco Bay - SW 


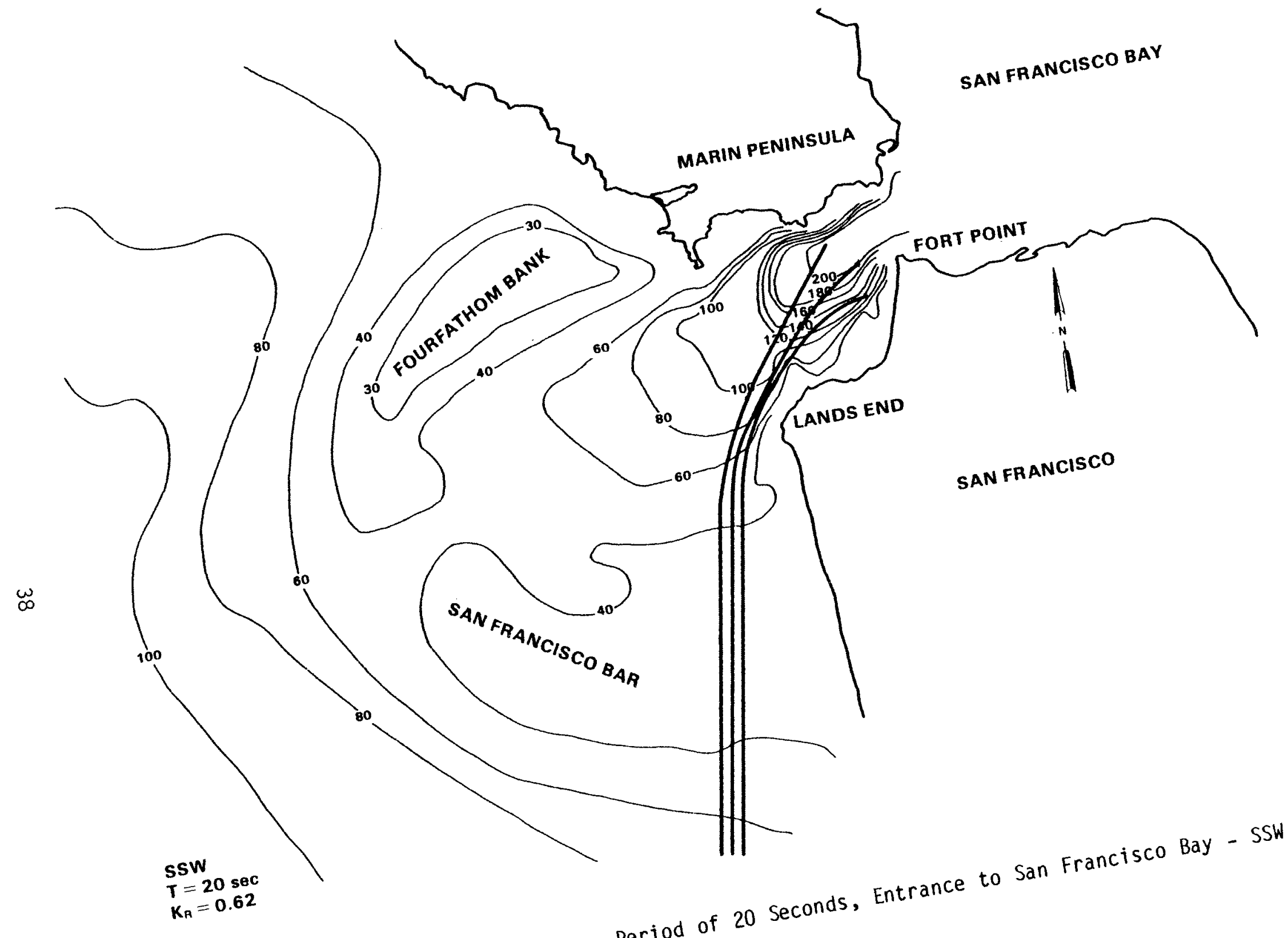


Thus, a wave height of 10 feet in deep water with a refraction coefficient of 0.5 and a shoaling coefficient of 0.9 would have a shallow water wave height of 4.5 feet.

The wave refraction coefficients in Table 11 generally decrease with increasing wave period, indicating that the wave height reduction increases with increasing wave period. The wave refraction coefficients vary from about 0.98 for a southwest wave with a period of 5 seconds to 0.37 for a westerly wave with a period of 20 seconds.

Table 12 is a tabulation of shoaling coefficients in Golden Gate Strait in 200 feet of water adjacent to Fort Point. Because of the deep water depths the shoaling coefficients for different period waves are slightly less than unity, meaning that there would be a slight wave height reduction as the deep water waves advance into the Golden Gate Strait.

Wave Refraction and Diffraction Around Fort Point

Long-period waves will approach the shoreline in the vicinity of Fort point Station at steep angles because of the severe refraction and diffraction around Fort Point. Wave diffraction is the phenomenon by which energy is transmitted laterally along a wave crest. Wave diffraction allows waves to be propagated into sheltered regions behind a barrier, such as a point or breakwater. The fort point Station is located in such a sheltered area in the lee of Fort Point for waves being propagated into San Francisco Bay through the Golden Gate Strait. However, due to refraction and diffraction at Fort Point, long-period waves can be propagated into this sheltered region.

\section{TABLE 12. Shoaling Coefficients, Golden Gate Strait}

\begin{tabular}{|c|c|}
\hline $\begin{array}{l}\text { Wave } \\
\text { Period } \\
\end{array}$ & $\begin{array}{l}\text { Shoaling } \\
\text { Coef, } \mathrm{K}_{\mathrm{S}}\end{array}$ \\
\hline 5 & 1.000 \\
\hline 10 & 0.974 \\
\hline 15 & 0.914 \\
\hline 20 & 0.935 \\
\hline
\end{tabular}


Wave diffraction phenomenon at Fort Point Station can be analyzed in accordance with methods described in the "Shore Protection Manual" (Ref 8). Wave height reductions, known as the diffraction coefficients, at Fort Point Station, are given in Table 13. The diffraction coefficient is defined as the ratio of the wave height $H$, in the area affected by diffraction to the wave height $H_{j}$, in the area unaffected by diffraction:

$$
H=K^{\prime} H_{i}
$$

Thus, if an incident wave with a height of 6 feet was diffracted in such a way as to result in a diffraction coefficient of 0.2 , the diffracted wave height would be 1.2 feet.

The wave diffraction coefficients, increase linearly with increasing wave period from 0.12 for a wave period of 5 seconds to 0.28 for a wave period of 20 seconds. The diffracted wave height at Fort Point Station of an incident wave with a height of 10 feet and period of 10 seconds would be 1.6 feet $(10 \mathrm{ft} \times 0.16)$.

Refracted deepwater waves from around Fort Point can also impinge on the Fort Point Station. Refraction diagrams for wave periods of $5,10,15$ and 20 seconds are shown in Figures 20 through 23 . Table 14 is a summary of the refraction coefficients and angle between the breaking wave crests and the shoreline. The wave refraction around Fort Point is quite severe with the refraction coefficients varying from 0.20 for a 15 -second period wave to 0.33 for a 5-second period wave. Refraction coefficients for 5- and 10-second

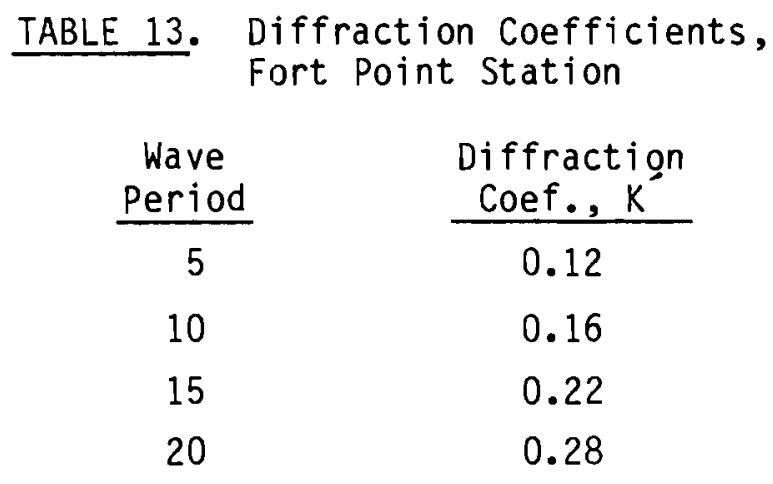




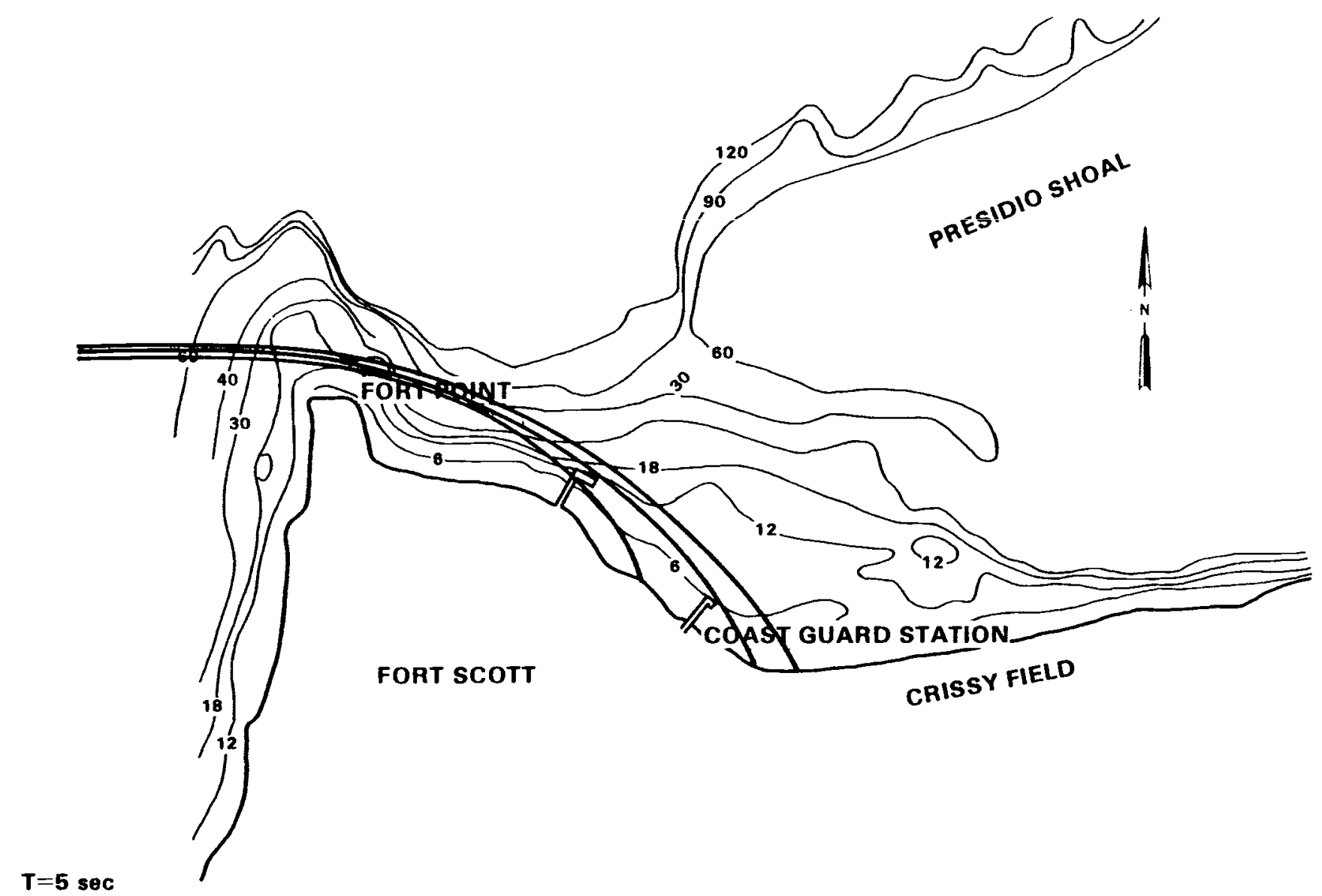

FIGURE 20. Wave Refraction for Wave Period of 5 Seconds, Fort Point Station 


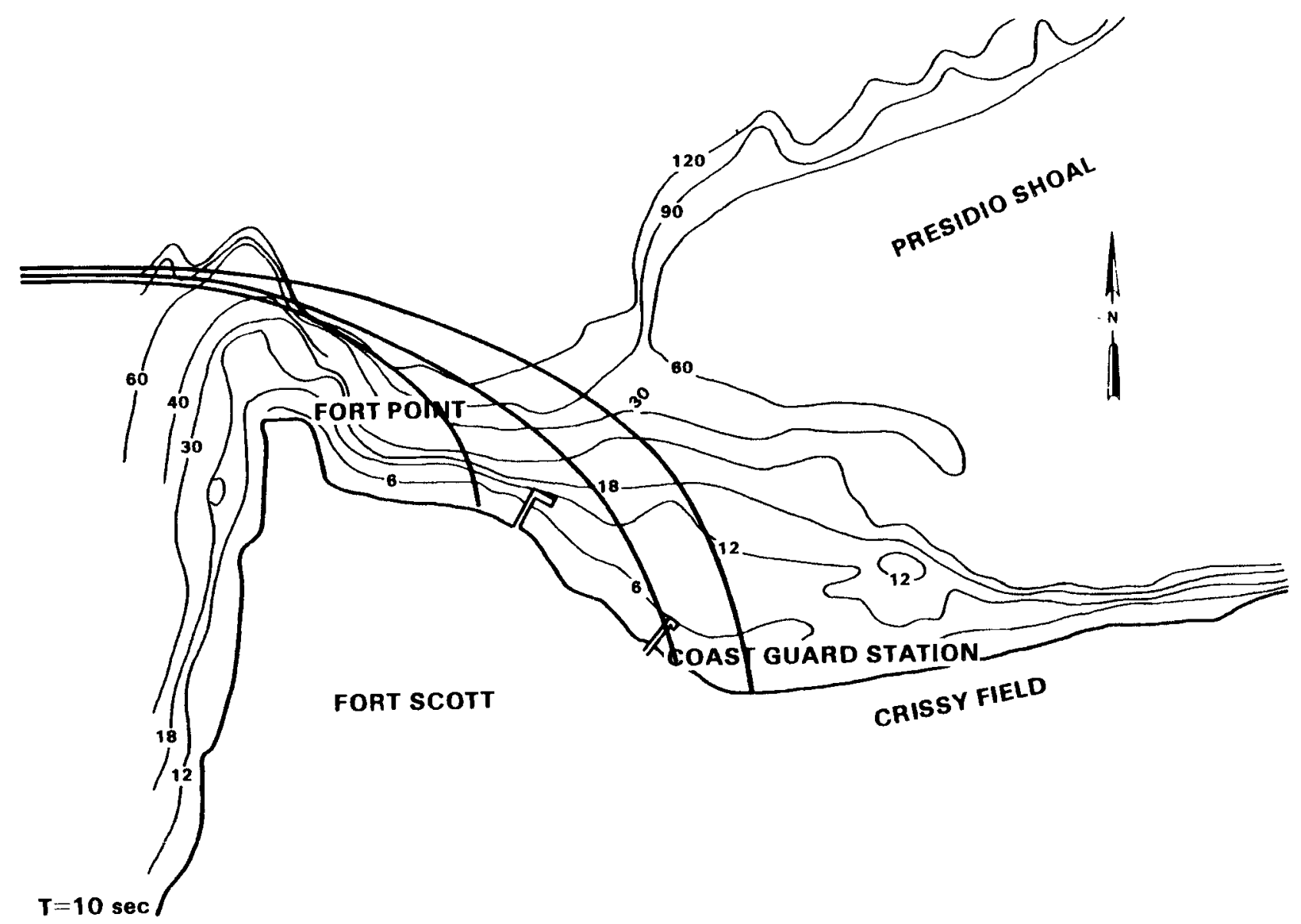

FIGURE 21. Wave Refraction for Wave Period of 10 Seconds, Fort Point Station 


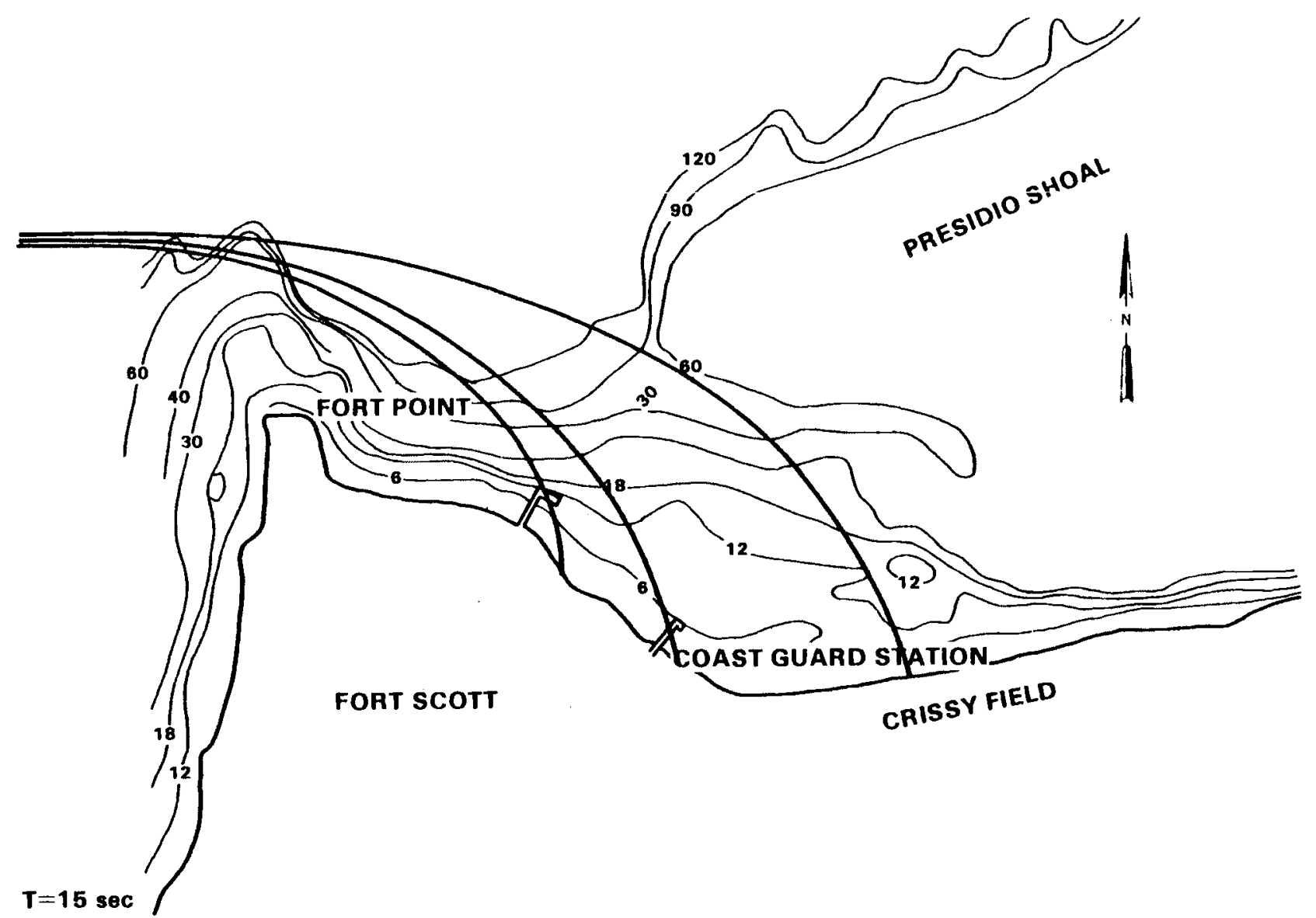

FIGURE 22. Wave Refraction for Wave Period of 15 Seconds, Fort Point Station 


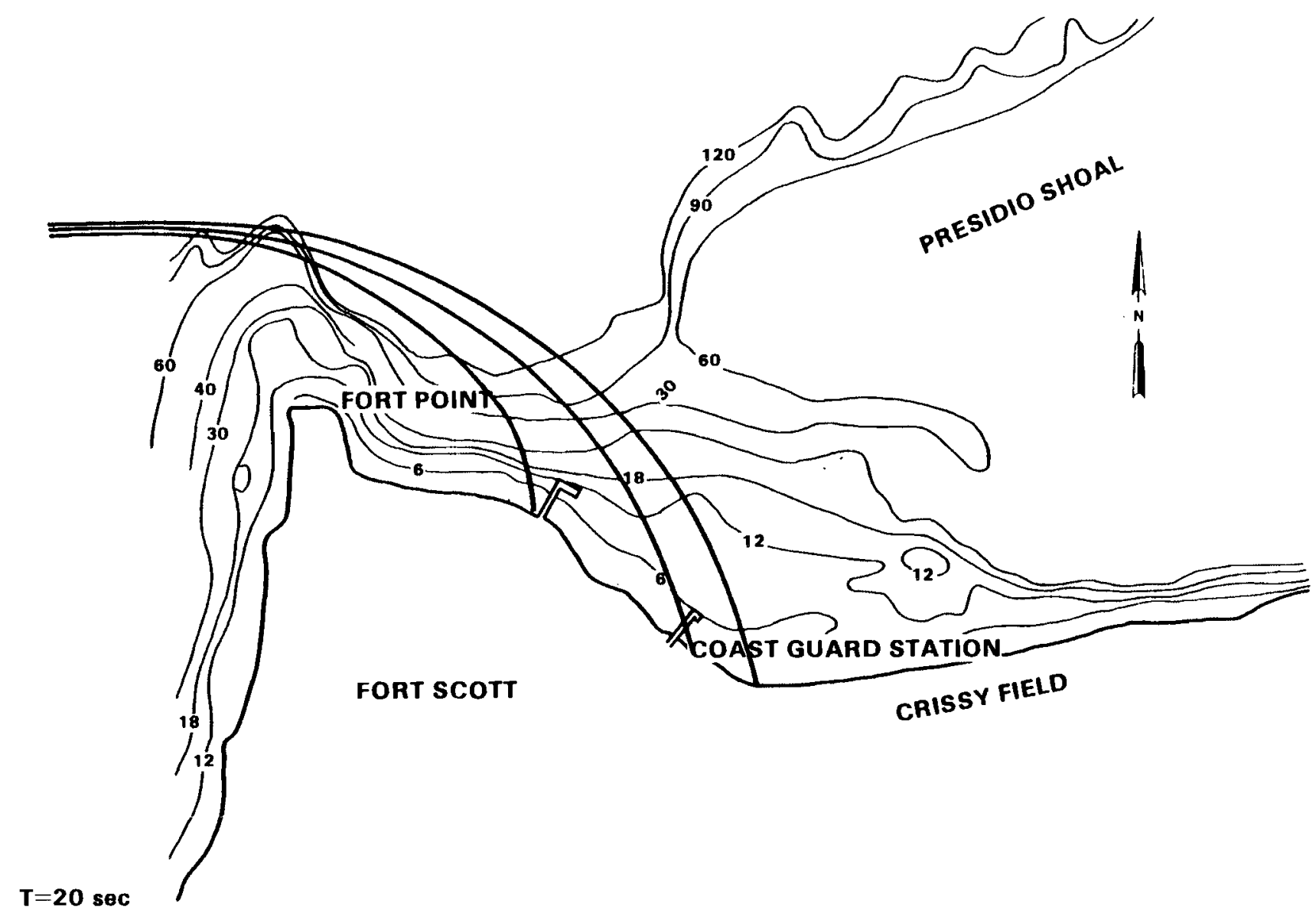

FIGURE 23. Wave Refraction for Wave Period of 20 Seconds, Fort Point Station 
TABLE 14. Refraction Coefficients and Breaking Wave Angles

with Shoreline, Fort Point Station

\begin{tabular}{|c|c|c|}
\hline $\begin{array}{l}\text { Wave } \\
\text { Period }\end{array}$ & $\begin{array}{l}\text { Refraction } \\
\text { Coef. } K_{R} \\
\end{array}$ & $\begin{array}{l}\text { Breaking } \\
\text { Angle, } \alpha\end{array}$ \\
\hline 5 & 0.33 & $64^{\circ}$ \\
\hline 10 & 0.22 & $47^{\circ}$ \\
\hline 15 & 0.20 & $49^{\circ}$ \\
\hline 20 & 0.24 & $48^{\circ}$ \\
\hline
\end{tabular}

period waves are larger than the corresponding diffraction coefficients and, therefore, would be used for determining wave heights at Fort Point Station from deepwater waves of these periods being propagated into San Francisco Bay. However, diffraction coefficients for wave periods of 15- and 20-seconds are slightly higher than the corresponding refraction coefficients, and therefore would be used to calculate wave heights for the longer-period waves.

Deepwater waves reaching Fort Point Station are also affected by shoaling. Table 15 is a summary of shoaling coefficients at the Fort Point Station pier in 10 to 15 feet of water. The shoaling coefficients increase with increasing wave period from 0.958 for a 5 -second period wave to 1.695 for a 20 -second period wave.

SUMMARY OF WAVE CONDITIONS AT FORT POINT STATION

As mentioned in the previous sections fort Point Station is subjected to short-period waves generated by wind in San Francisco Bay and long-period waves transmitted into San Francisco Bay through Golden Gate Strait from the Pacific Ocean.

Tables 3 and 4, summary of maximum wind speeds, and Tables 6 and 7, significant wave heights and periods for given wind speeds, can be used to compute the highest significant wind-generated waves at Fort Point Station. Tables 2, 6 and 7 will be used in later sections to compute longshore sediment transport rates at Fort Point Station due to wind-generated waves in the Bay.

Table 16 is a summary of the highest significant wind-generated waves at Fort Point Station for each of the exposed fetches based on Table 3. The 
TABLE 15. Shoaling Coefficients, Fort Point Station

\begin{tabular}{ccc}
$\begin{array}{c}\text { Wave } \\
\text { Period }\end{array}$ & & \multicolumn{2}{c}{$\begin{array}{l}\text { Shoaling } \\
\text { Coef, } \mathrm{K}_{\mathrm{s}}\end{array}$} \\
5 & & 0.958 \\
10 & & 1.233 \\
15 & 1.483 \\
20 & & 1.695
\end{tabular}

TABLE 16. Highest Significant Wind-Generated Wave Heights at Fort Point Station

\begin{tabular}{|c|c|c|c|}
\hline $\begin{array}{c}\text { Fetch } \\
\text { Direction }\end{array}$ & $\begin{array}{c}\text { Maximum } \\
\text { Wind Speed } \\
\text { mph } \\
\end{array}$ & $\begin{array}{l}\text { Significant } \\
\text { Wave Height } \\
\mathrm{ft}\end{array}$ & $\begin{array}{c}\text { Significant } \\
\text { Wave Period } \\
\text { sec }\end{array}$ \\
\hline$W$ & 43 & 1.3 & 2.2 \\
\hline WNW & 43 & 2.1 & 2.9 \\
\hline$N W$ & 39 & 2.2 & 3.0 \\
\hline NNW & 39 & 2.5 & 3.2 \\
\hline $\mathrm{N}$ & 43 & 3.1 & 3.5 \\
\hline NNE & 33 & 2.9 & 3.5 \\
\hline $\mathrm{NE}$ & 30 & 2.8 & 3.4 \\
\hline ENE & 30 & 2.6 & 3.3 \\
\hline$E$ & 26 & 2.0 & 2.9 \\
\hline ESE & 33 & 1.5 & 2.4 \\
\hline
\end{tabular}

highest significant wind-generated wave height at Fort Point Station for the maximum sustained wind speeds shown in Table 3 is 3.1 feet from the north. The corresponding wave period is 3.5 seconds. Using Table 4 and assuming that the maximum estimated peak offshore surface wind speeds were unattenuated as they approached the land mass, the largest wind-generated significant wave height with a return period of 50 years from the west is 3.0 feet and the significant wave period is 3.2 seconds.

Deepwater waves transmitted into San Francisco Bay are affected by refraction and shoaling across San Francisco Bar and refraction, diffraction and shoaling as they approach Fort Point Station. Table 17 summarizes the combined 
TABLE 17. Combined Wave Refraction, Diffraction, Shoaling Coefficients, Fort Point Station for Long-Period Waves

\begin{tabular}{|c|c|c|c|c|}
\hline & \multicolumn{4}{|c|}{ Wave Period } \\
\hline Direction & $5 \mathrm{sec}$ & $10 \mathrm{sec}$ & $15 \mathrm{sec}$ & $20 \mathrm{sec}$ \\
\hline WNW & - & 0.22 & 0.18 & 0.24 \\
\hline W & 0.23 & 0.12 & 0.14 & 0.16 \\
\hline WSW & 0.29 & 0.19 & 0.19 & 0.25 \\
\hline SW & 0.31 & 0.18 & 0.18 & 0.27 \\
\hline SSW & - & 0.14 & 0.16 & 0.28 \\
\hline
\end{tabular}

effects of refraction, diffraction and shoaling as the deepwater waves approach Fort Point Station. The combined coefficients in Table 17 for each wave direction and period multiplied by the corresponding deepwater wave heights will yield the wave heights at Fort Point Station. Tables 9 and 10, highest significant deepwater wave heights, and Table 17 can be used to calculate the highest significant wave heights at Fort Point Station due to deepwater waves entering San Francisco Bay. Tables 8 and 16 will be used in later sections to compute longshore sediment transport rates at Fort Point Station due to deepwater waves transmitted into the Bay.

Table 18 is a summary of the highest significant waves impinging on Fort Point Station from deep water. The highest significant wave height at Fort Point Station is 5.2 feet resulting from a deepwater wave from WNW with a height of 26 feet and period of 13 seconds. Even though the deepwater wave height from the west is larger (33 feet), the corresponding height at Fort point Station would be lower ( 4.3 feet) due to greater refraction of waves from the west. 
TABLE 18. Highest Significant Waves at Fort Point Station from Deepwater Waves

\begin{tabular}{ccccc}
$\begin{array}{c}\text { Deepwater Wave } \\
\text { Direction }\end{array}$ & $\begin{array}{c}\text { Deepwater Wave } \\
\text { Height } \\
\mathrm{ft}\end{array}$ & 26 & $\begin{array}{c}\text { Signif. Wave Height } \\
\text { at Fort Point Station } \\
\mathrm{ft}\end{array}$ & $\begin{array}{c}\text { Wave } \\
\text { Period } \\
\text { sec }\end{array}$ \\
\cline { 2 - 3 } WNW & 33 & 5.2 & $\begin{array}{c}13 \\
\text { W }\end{array}$ \\
\cline { 2 - 3 } WSW & 20 & 4.3 & 13 \\
SW & 16 & 3.8 & 13 \\
SSW & 8 & 3.2 & 10 \\
& 26 & 1.2 & 13
\end{tabular}


SEDIMENT SOURCES AND TRANSPORT

Fort Point Station is located on a sandy beach extending about 0.3 miles northwest and one mile southeast of the Station. Construction of all-weather moorings facility at Fort Point Station about midway along the sandy beach could potentially alter the beach stability conditions, causing existing sedimentation/erosion patterns to change, and disrupt the longshore sediment transport patterns along the beach. Potential changes in the longshore sediment transport patterns and alterations of sedimentation/erosion patterns must be evaluated when determining the engineering feasibility of all-weather moorings construction at Fort point Station.

\section{SOURCES OF BEACH SEDIMENTS}

There are two possible sources of beach sediments for the beach between Fort Point and San Francisco Yacht Harbor. These are the sand deposits of Presidio/Alcatraz Shoal lying offshore of the Fort Point Station and beach deposits outside the Golden Gate Strait which are transported along the south shoreline of Golden Gate Strait and into San Francisco Bay by the prevailing westerly waves.

Presidio/Alcatraz Shoal is comprised of fine to medium grained sand. The shoal is an interior bay mouth bar thought to have originated in part from littoral sediments transported into San Francisco Bay by longshore transport along the ocean coastline, and in part by sandy sediments originating in the Sacramento/San Joquin River system and transported towards the entrance to San Francisco Bay throughout the geologic past. There is a possibility that some of these sandy deposits could be transported onshore by tidal currents in the vicinity of Fort Point Station, providing a source of sand for the natural maintenance of the beach.

The other possible source of sand is that originating outside the Golden Gate Strait and transported in a northerly direction along San Francisco's ocean Beach, around Point Lobos and Lands End, easterly along Baker Beach, around Fort Point, and to the southeast along Fort Point Beach where the longshore sand transport is finally interrupted by the presence of the San 
Francisco Yacht Harbor breakwater. This second source of sand for the Fort Point Beach is the most critical since any solid barrier across the beach in the form of all-weather moorings, could disrupt the longshore transport of sand to the east of the barrier, depriving the beach of sand to maintain it in a stable condition. Observations by Coast Guard and National Park Service personnel this last winter (1982-1983) indicate that sand originating outside the Golden Gate Strait is an important source of sand for Fort Point Beach. The accumulation of sand on Fort Point Beach during the winter of 1982-1983 was very large even though severe wave conditions prevailed along the north central coast of California. At least seven severe storms from the southwest through west accompanied by high waves resulted in extremely large sand losses along San Francisco's Ocean Beach. The sand losses at Dcean Beach, alone, were in excess of 500,000 cubic yards. These storms from the southwest through west would cause large sand transport rates to the north along Ocean Beach, thence along the Golden Gate Strait shoreline into San Francisco Bay, and onto Fort Point Beach. Because the wave conditions inside San Francisco Bay are much more tranquil than along the ocean coastline, the sand transported into the Bay from outside the Golden Gate Strait would be deposited along Fort Point Beach, resulting in large sand accumulations during these severe storms.

\section{LONGSHORE SEDIMENT TRANSPORT}

Longshore (1ittoral) transport is the process by which sediment in the nearshore zone is moved by waves and currents. Longshore transport results from the stirring up of sediment by breaking waves, and movement of the sediment in an alongshore direction by longshore currents generated by breaking waves or tidal currents. Tidal currents can transport sediment in the nearshore zone without the presence of waves if the velocities become large enough to initiate the movement of sediment particles.

Longshore Sediment Transport By Waves

The rate of longshore transport by waves is dependent on both the angle of wave approach and available wave energy. Thus, large waves will move more material per unit time than low waves. Reversals in transport direction can occur as a result of changes in wave approach. 
Longshore sediment transport rates by waves are usually given in units of volume per unit time (cubic yards per year). Typical longshore transport rates along the exposed coasts of the United States vary from 8,000 - 90,000 cubic yards per year in the Great Lakes to 30,000 - 1,000,000 cubic yards per year along the Atlantic and Pacific Coasts (Ref 8). The longshore sediment transport rates along San Francisco's Ocean Beach have been estimated to be between one and two million cubic yards per year (Ref 12). One would expect the longshore transport rates along the protected Fort Point shoreline to be substantially less than those along the exposed Ocean Beach shoreline.

The best method for predicting longshore sand transport at a site due to waves is to adopt the best known rate from a nearby side, with modifications based on local conditions. If rates from nearby sites are unavailable or are known to vary considerably, the next best way to predict transport rates is to compute them from data showing historical changes in nearshore depths and shoreline position. If neither of these two methods are practical, then it is accepted practice to use either measured or calculated wave conditions to compute the longshore component of wave energy (wave energy flux), then relate this energy through empirical relationships to the longshore sediment transport rate $(\operatorname{Ref} 8)$.

Since there is a lack of data on longshore sediment transport rates in the vicinity of Fort Point Station, longshore transport rates in this report will be based on the energy flux method. This method uses the wave height, wave period, wave angle relative to the shoreline, and frequency of occurrence of waves of a given height and direction. The following transport equations are used to estimate longshore sediment transport at Fort Point Station due to waves:

$$
\begin{gathered}
P_{\ell S}=\frac{P g^{2}}{64 \pi} T\left(H_{0} K_{R} K_{s}\right)^{2} \sin 2 \alpha_{b} \\
Q=\left(7.5 \times 10^{3}\right) \mathrm{fP} \ell \mathrm{s}
\end{gathered}
$$


where $Q=$ longshore sediment transport in cubic yards per year

$\mathrm{p}^{\ell s}=$ longshore component of wave energy flux in $\mathrm{ft}-\mathrm{lbs} / \mathrm{ft}-\mathrm{sec}$

$\rho=$ density of water $64.4 \mathrm{lbs}$ per cubic $\mathrm{ft}$

$\mathrm{g}=$ acceleration of gravity $32.2 \mathrm{ft}^{2} / \mathrm{sec}$

$T=$ wave period

$H_{0}=$ deepwater wave height

$K_{R} K_{S}=$ refraction and shoaling coefficients

$\alpha_{b}=$ breaking wave angle with shoreline

$f=$ frequency of occurrence of wave of a given height, period and direction

Longshore sediment transport rates due to waves at Fort Point Station are based on both wind-generated waves within San Francisco Bay and transformed waves transmitted through Golden Gate Strait. Longshore sediment transport from wind-generated waves are computed from Table 1 and longshore sediment transport from waves transmitted through Golden Gate Strait are computed from Table 8. The computed longshore transport rates are estimates of the "potential" transport, or that volume of sediment that would be transported by the prevailing wave conditions past fort point Station if an unlimited supply of beach sediment was available for transport.

Table 19 is a tabulation of "potential" longshore sediment transport rates at Fort point Station due to wind-generated waves and waves transmitted through Golden Gate Strait. Longshore sediment transport due to waves is almost exclusively to the east with an estimated net rate of 73,050 cubic yards per year $(c y / y r)$. There is a slight westerly transport due to wind-generated waves from the northeast through east southeast, amounting to about $850 \mathrm{cy} / \mathrm{yr}$, giving the gross longshore sediment transport rate of $74,750 \mathrm{cy} / \mathrm{yr}$. Longshore sediment transport at Fort Point Station due to waves being transmitted through Golden Gate Strait is an order of magnitude greater than that due to wind-generated waves in San Francisco Bay. The net transport due to these deepwater waves is $66,550 \mathrm{cy} / \mathrm{yr}$ compared to $6,500 \mathrm{cy} / \mathrm{yr}$ from wind-generated waves. 
TABLE 19. Longshore Sediment Transport at Fort Point Station Due to Waves

\begin{tabular}{|c|c|c|c|}
\hline Direction & $\begin{array}{l}\text { Transport Due to Wind- } \\
\text { Generated Waves cy/yr } \\
\end{array}$ & $\begin{array}{l}\text { Transport Due to } \\
\text { Deepwater Waves cy/yr }\end{array}$ & Total \\
\hline SSW & 0 & -150 & -150 \\
\hline SW & 0 & $-1,000$ & $-1,000$ \\
\hline WSW & 0 & $-8,250$ & $-8,250$ \\
\hline$w$ & 0 & $-13,950$ & $-13,950$ \\
\hline WNW & 0 & $-43,200$ & $-43,200$ \\
\hline NW & -650 & 0 & -650 \\
\hline NNW & $-2,750$ & 0 & $-2,750$ \\
\hline N & $-3,600$ & 0 & $-3,600$ \\
\hline NNE & -350 & 0 & -350 \\
\hline NE & +150 & 0 & +150 \\
\hline ENE & +250 & 0 & +250 \\
\hline$E$ & +300 & 0 & +300 \\
\hline ESE & +150 & 0 & +150 \\
\hline NET & $-6,500$ & $-66,550$ & $-73,050$ \\
\hline GROSS & 8,200 & 66,550 & 74,750 \\
\hline
\end{tabular}

The longshore sediment transport rates at Fort Point Station due to waves are small in comparison to the exposed coastline of California, but are probably substantially larger than other places in San Francisco Bay because of the influence of waves being transmitted through Golden Gate Strait.

Sediment Transport Due to Currents

Predictive sediment transport due to currents in bays relies heavily on the work of Kachel and Sternberg (Ref. 13) and Sternberg (Ref. 14). Their work focused on a predictive method for estimating bedload sediment transport. Specifically, their studies have focused on the tidal channels in Puget Sound, Washington with bed load being evaluated from current ripple migration rates observed on the sea floor. The transport relationship presented by Kachel and 
Sternberg were based on the developments of Bagnold (Ref. 15) who related the rate of mass transport of sediment as bedload to the power expended by the fluid moving over the boundary.

The amount of bedload sediment transport is a function of the sediment size, flow and fluid characteristics, topography, etc. Data published by Johnson (Ref. 16) provides information regarding the grain size of sediment on the Bay side of the Golden Gate Bridge. The four closest samples taken to the bridge have an average median grain diameter $\left(d_{50}\right)$ of $0.39 \mathrm{~mm}$. The median grain diameter represents the diameter of the sediment in which $50 \%$ of the material is finer or coarser by weight. Outside San Francisco Bay along Baker Beach, west of Fort Point, the median grain size of sediment is $0.41 \mathrm{~mm}$. Figure 24 presents the cumulative logrithmic probability size-frequency graph for the Baker Beach sample. The median grain diameter of $0.40 \mathrm{~mm}$ was obtained by averaging both samples (i.e., $0.39 \mathrm{~mm}$ and $0.41 \mathrm{~mm}$ ). A median grain diameter of $0.40 \mathrm{~mm}$ was employed in all sediment computations.

The flow characteristics were described by a temporal and spacial distribution of flow current velocities. The temporal distribution of current velocities was described previously in Figures 3 and 4 . The tidal current charts for San Francisco Bay for maximum flood and ebb tides USDC (Ref. 5) on which Figure 3 is based represent the only information on current velocities and direction. These current velocities appear applicable, though, only at a location 0.5 miles offshore of Fort Point Station in an area where the depth is approximately $52 \mathrm{ft}$. No spacial distribution or information on the velocity profile is available in the immediate vicinity of Fort Point Station. In order to proceed with the sediment transport analysis, a vertical velocity profile was assumed. The profile represented a composite of the power-law and velocity-defect (logrithmic) law distributions (Karim and Kennedy 1981, and Daley and Harleman 1966, Refs 17,18$)$.

Based on the assumed velocity profile sediment characteristics and predictive transport methods of Kachel and Sternberg (Refs. 13,14), an estimate of sediment transport on the bed by tidal currents was made at a location of 0.5 miles offshore of Fort Point Station. The estimated bed load transport for the ebb current at this location is 7.41 tons per year per foot of width of 


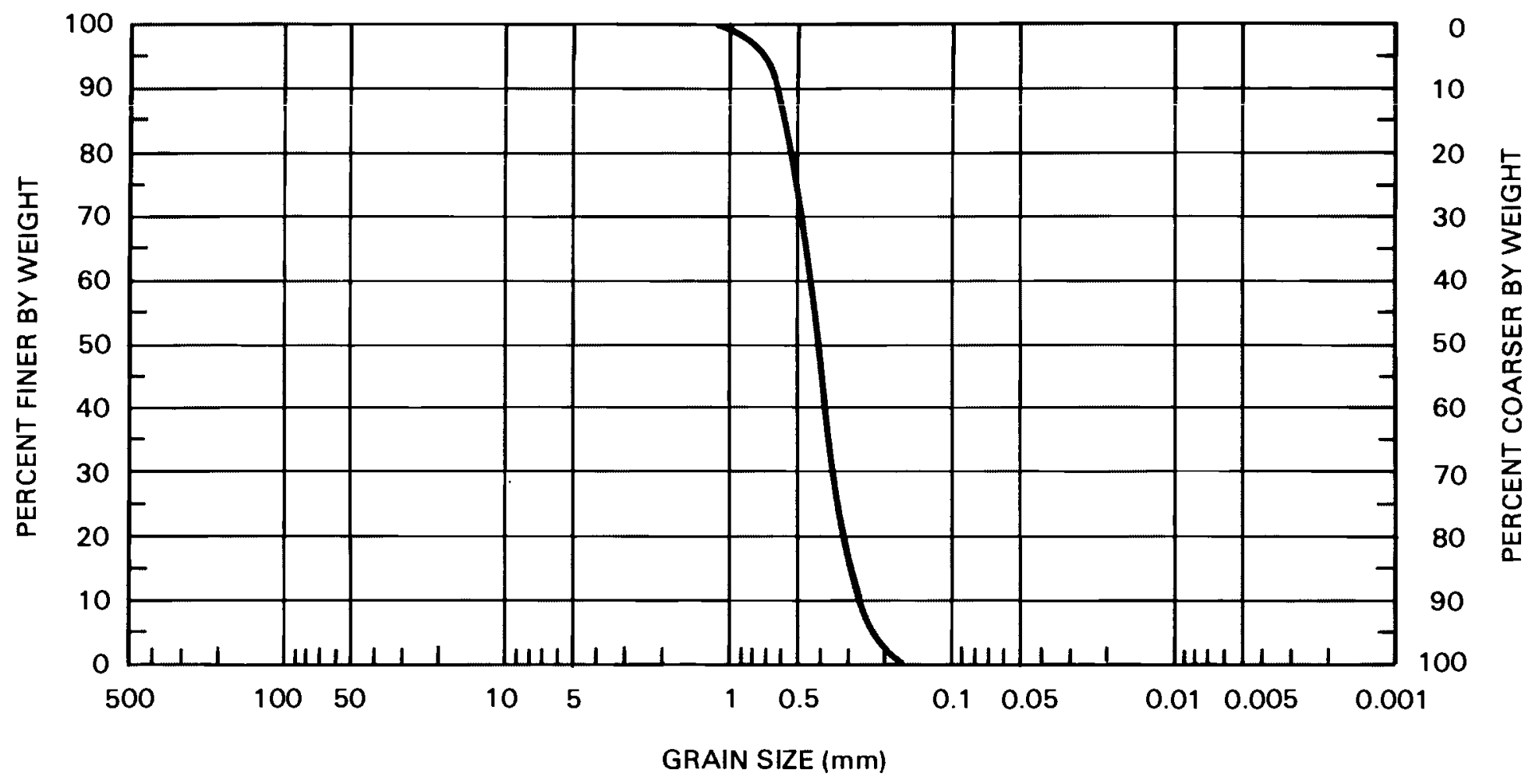

\begin{tabular}{|c|c|c|c|c|c|}
\hline \multirow{2}{*}{ COBBLES } & \multicolumn{2}{|c|}{ GRAVEL } & \multicolumn{2}{c|}{ SAND } & \multirow{2}{*}{ SILT OR CLAY } \\
\cline { 2 - 4 } & COARSE & FINE CCOARSE MEDIUM & FINE & \\
\hline
\end{tabular}

FIGURE 24. Sediment Size Distribution, Baker Beach 
channel and for flood current the estimated bed load transport is 0.002 tons per year per foot of width. Since the ebb tidal currents are directed out the Golden Gate Strait, there is a large predominance of sediment being transported out of the Bay.

These results do not necessarily represent conditions in the immediate vicinity of Fort Point Station where reversals in flood and ebb flows do exist. The analysis does indicate, however, that the potential for bed load sediment movement by currents in the immediate vicinity of Fort Point Station could be significant and that this movement could have some effect on shoaling within the all-weather moorings basin. 


\section{ALL-WEATHER MOORINGS DESIGN ALTERNATIVES, FORT POINT STATION}

There are a number of design alternatives for all-weather moorings at Fort Point Station that could accomplish the objective of decreasing the wave heights at the Station in order to provide safe working conditions for SAR crews and allow routine maintenance of the Motor Life Boats. These include shore connected breakwater, detached breakwater, and dredged basin. These different types of structures could have different potential impacts on the physical environment and the degree of change or alterations to the physical environment could vary between alternatives. Floating breakwaters and wave attenuators have been deleted from further discussion because they would not meet the objective of decreasing the wave heights at the Station to acceptable levels. This is due to the long-period waves transmitted through Golden Gate Strait from the Pacific Ocean, the height of the design wave, and the wide angle of exposure from both wind-generated waves within San Francisco Bay and deepwater ocean waves.

The materials used for construction will have little effect on physical processes; however, the type of materials will have an effect on the design and cost of the structure. For instance, a concrete structure would probably have to be designed for a 1 percent wave height, whereas a rubble mound structure could be designed for the significant wave height. Design for a 1 percent wave would require a more massive structure with correspondingly higher costs. Most of the design considerations in this section will be based on rubble mound structures for consistency. Drawings of alternative designs in this section are conceptual in nature and have been prepared only for the purpose of iliustrating differences in concept, required basin size, and evaluation of potential effects to the physical environment.

The size of the all-weather moorings structure is dictated by the number of required berths, the protected turning basin diameter and width of the entrance channel. Evaluation of the all-weathering moorings alternatives is based on the minimum requirements of three berths of about 45 feet in length and 15 feet in width, a turning basin diameter 55 feet at MLLW, and entrance channel of 40 feet width at MLLW. 
SHORE-CONNECTED BREAKWATER

A conceptual drawing of a shore-connected breakwater at Fort Point Station, providing the minimum berthing requirements is shown on Figure 25 . The shore-connected breakwater consists of two rubble mound breakwaters with side slopes of 1-1/2:1. The major breakwater extends perpendicular to the shoreline from the highest estimated tide to a water depth of about 10 feet below MLLW, then makes a dog-leg and runs parallel to the shoreline. The secondary breakwater extends perpendicular to the shoreline and is in line with the end of the dog-leg of the major breakwater, thus enclosing the berthing area in a protected basin. The total length of the two breakwaters is about 775 feet. The actual shape of the breakwaters is not critical as long as the dog-leg is located in deep enough water to prohibit the unimpeded transport of sediment around the outer portion of the breakwater and into the entrance channel and basin. The configuration of the breakwaters is important in that the entrance channel should be oriented in such a way as to minimize the diffracted wave heights within the basin, and to minimize the volume of sediment transported by waves and currents into the basin. These considerations are evaluated in the section on design considerations. The size of the shore-connected breakwater is also important in that the minimum berths, turning basin diameter, operating depth, and entrance channel width dictate, to some degree, the size of the structure.

\section{DETACHED BREAKWATER}

Conceptual drawings of detached breakwaters are shown on Figure 26 . Two configurations are shown, one with a circular breakwater alignment and the other with a triangular alignment. These two configurations are illustrated to show that the length of the breakwater for a circular alignment is shorter for the same number of berths, turning basin diameter and entrance channel width. The detached breakwater would be placed offshore at a depth of 10 feet or more below MLLW. Access to the basin would be provided by an open face causeway extending from the beach to the breakwater, similar to the existing structure at the Station. The breakwater is a rubble mound structure with side slopes of 


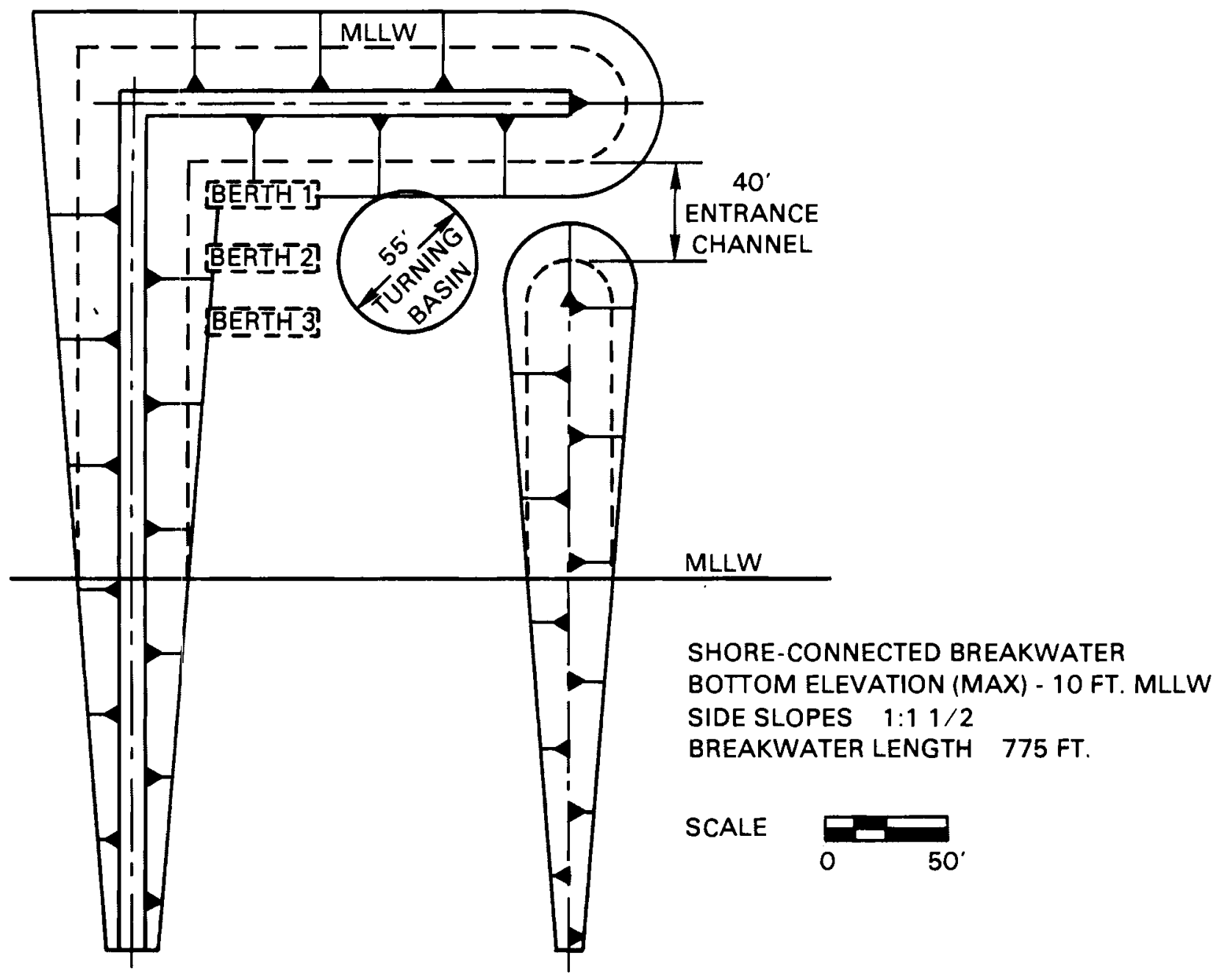

FIGURE 25. Shore Connected Breakwater 


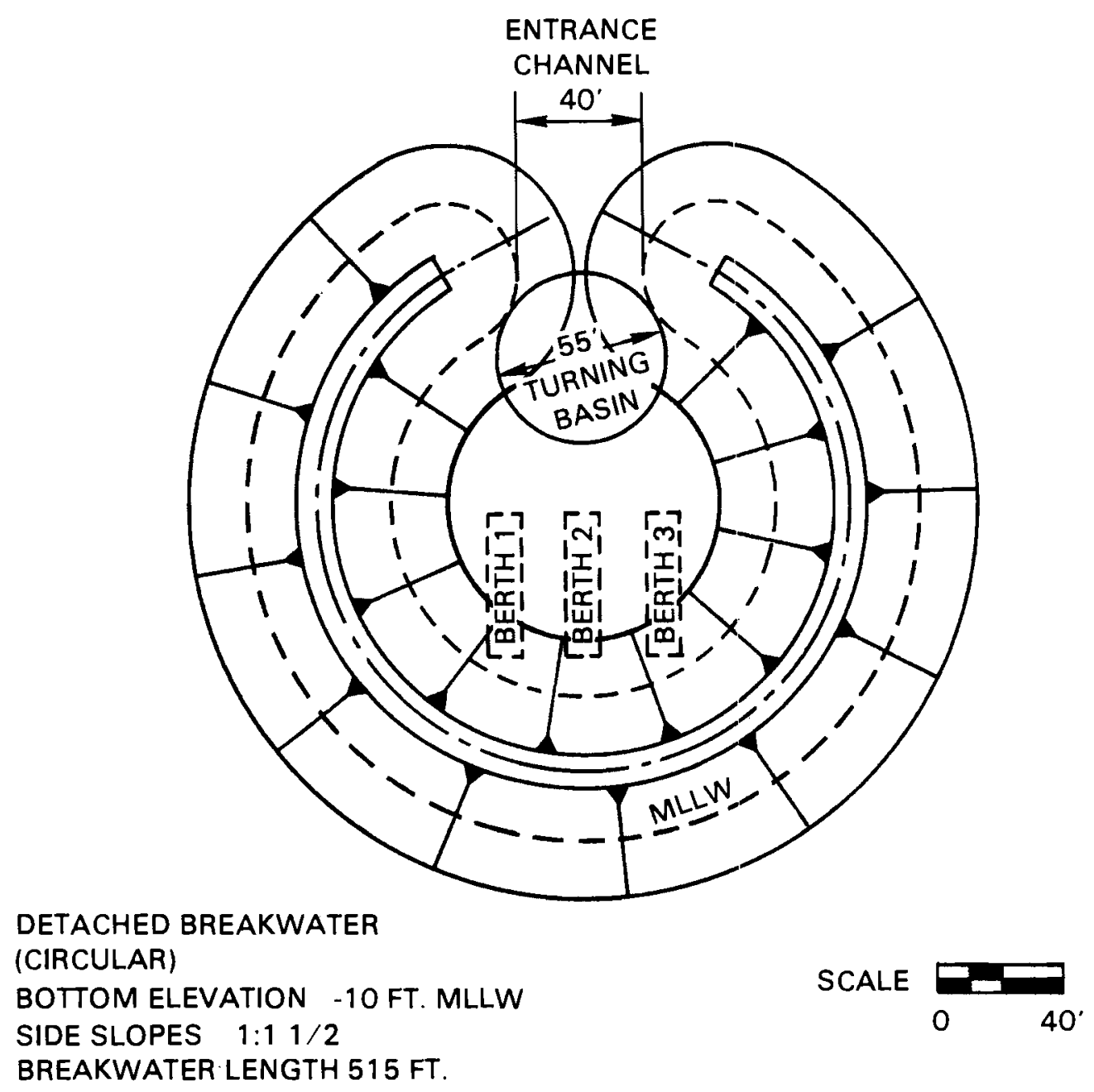

FIGURE 26. Detached Breakwater 


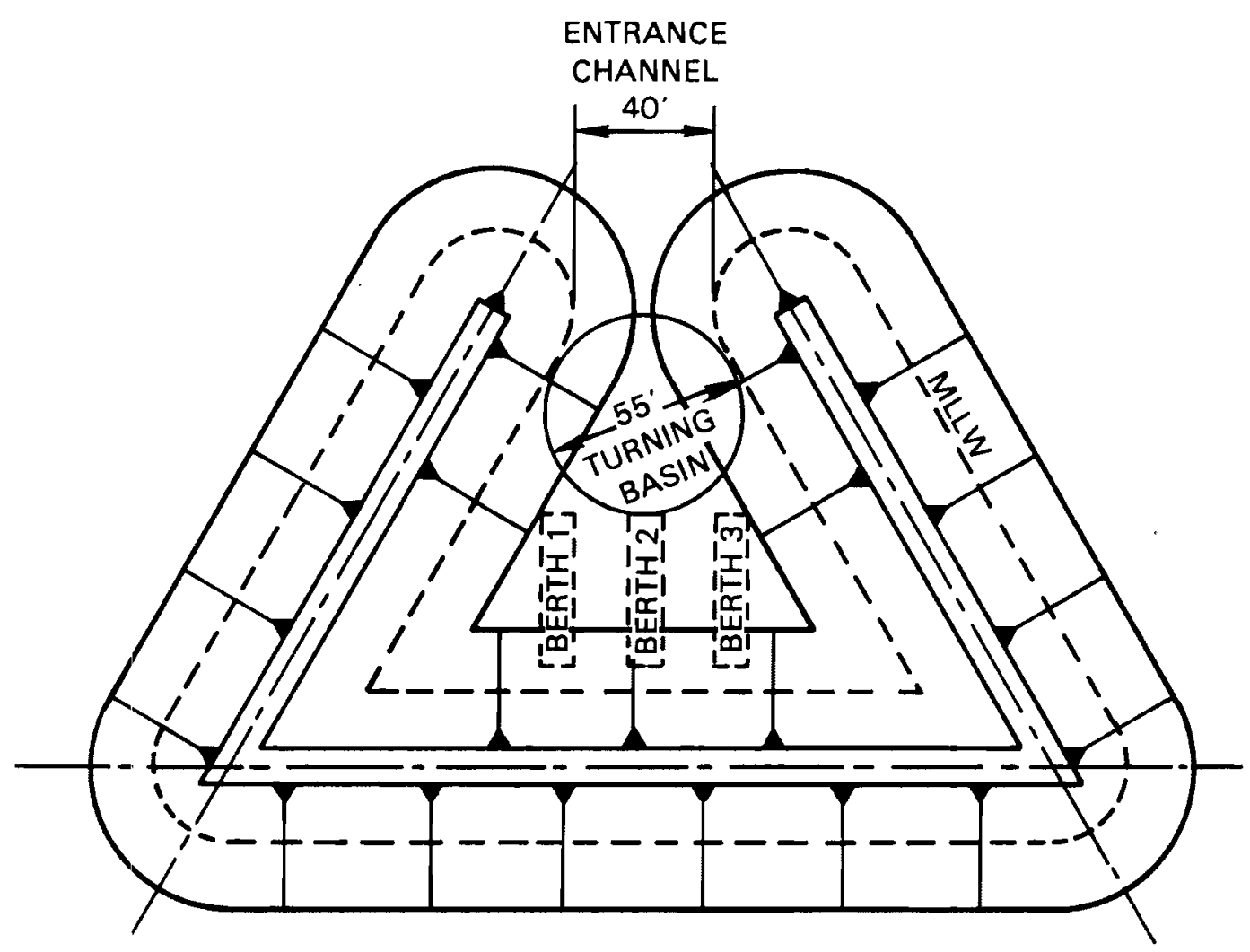

DETACHED BREAKWATER

(TRIANGIULAR)

SIDE SL.OPES $1: 11 / 2$

BREAKWATER LENGTH $530 \mathrm{FT}$.

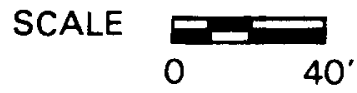

FIGURE 26. (contd)

$1-1 / 2: 1$. The minimum length of the breakwater is about 515 for a circular configuration and 530 feet for a triangular configuration. The entrance channel of a detached breakwater should be oriented in such a way as to minimize the diffracted wave heights within the basin, and minimize the volume of sediment transported into the entrance channel and basin by tidal currents. The placement of the detached breakwater seaward of the zone of longshore sediment transport by waves would eliminate the concern of sediments entering the basin from longshore transport by waves. The distance of the detached breakwater from the shoreline and size of the structure will dictate how the structure will affect the longshore transport of sediment by waves. The 
further offshore the structure is placed and the smaller the structure, the lesser will be the effect on longshore sediment transport by waves. These considerations are evaluated further in the section on design considerations.

\section{DREDGED BASIN}

A conceptual drawing of a dredged basin landward of the highwater line is shown on Figure 27. The dredged basin would consist of a 100-foot square basin landward of the highwater line, a 60-foot wide entrance channel across the beach with a minimum operating depth of 5 feet below MLLW, and sheet pile jetties on either side of entrance channel to prevent beach sediments from shoaling the entrance channel. The westerly jetty would have to be longer than the easterly jetty, because the predominant direction of longshore sediment transport by waves is to the east. The west jetty would have to extend seaward to about the -10 feet, MLLW contour, whereas the east jetty would have to extend seaward to at least the -5 feet, MLLW contour (extent of dredging). The combined length of the two jetties would be about 400 to 500 feet. The size of the dredged basin and entrance channel would dictate the maintenance dredging requirements. In addition, the jetties would provide an almost total littoral barrier to the longshore transport of sediment along the beach. These considerations along with others are evaluated in the section on design considerations. 
-10 FT MLLW

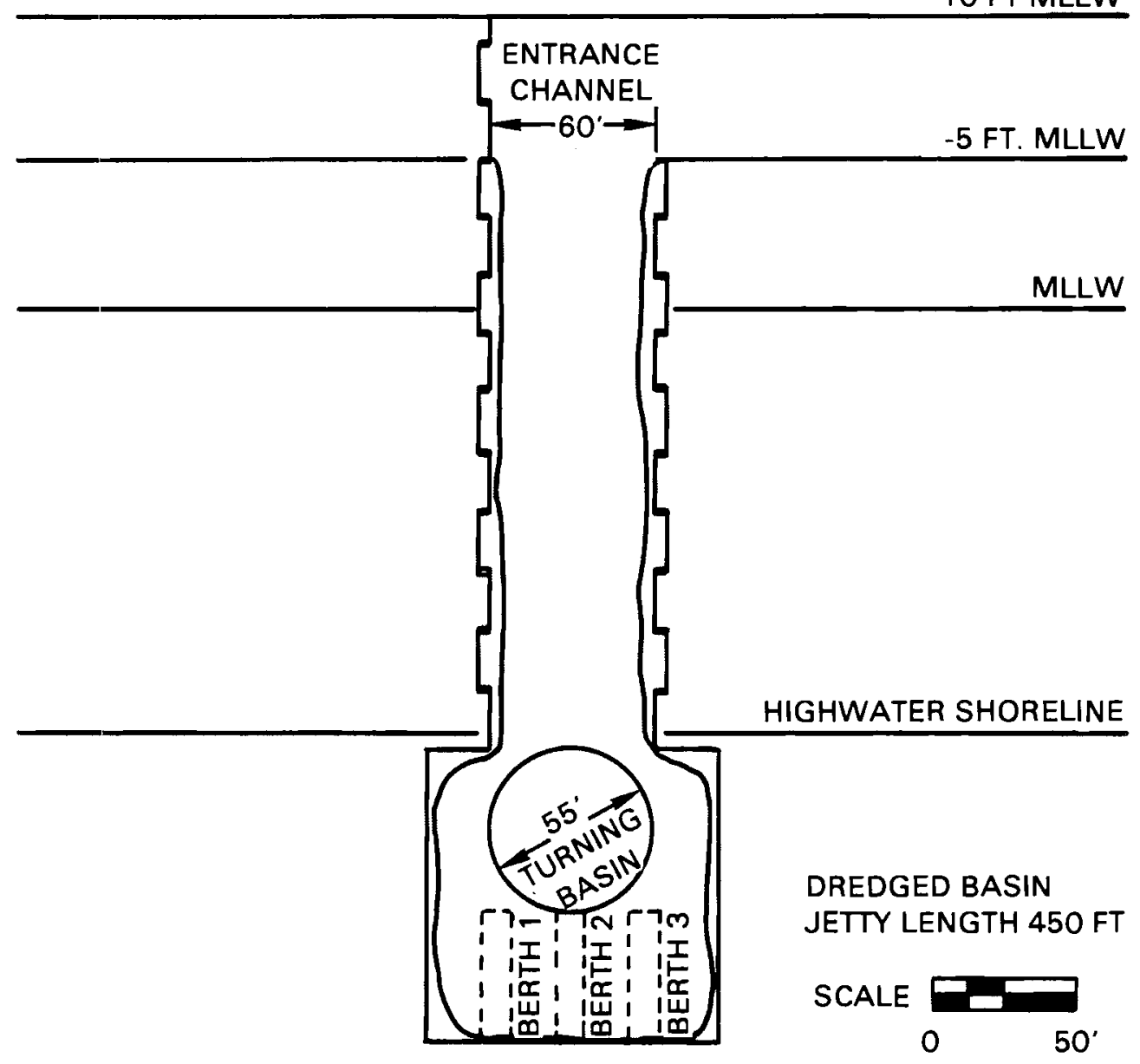

FIGURE 27. Dredged Basin 
assumed page 


\section{DESIGN CONSIDERATIONS - FORT POINT STATION}

The wave climate at Fort Point Station is suitable for construction of a11-weather moorings. However, long-period, deepwater waves transmitted through Golden Gate Strait from the Pacific Ocean do impose some restrictions on the type of all-weather moorings to provide adequate wave protection. Floating breakwaters and sheet pile wave attenuators, for instance, will not provide adequate protection against long-period waves transmitted through Golden Gate Strait. All-weather moorings at Fort Point Station are limited to solid impermeable type structures because of these long-period waves. Design considerations will be discussed in this section along with a comparative evaluation of the conceptual design alternatives.

DESIGN WAVE HEIGHT

Waves produce the most critical forces to which a structure in the nearshore zone is subjected. A structure should be designed to withstand the highest wave expected to impinge on the structure, if such a design is economically justified. Economic evaluations depend on the frequency of occurrence of extreme events such as height and duration of extreme waves, damage potential of high waves, and permissible risk.

The highest significant wave heights impinging on Fort Point Station for both wind-generated waves within San Francisco Bay and deepwater waves transmitted through Golden Gate Strait are given in Table 20. Significant waves are defined as the average of the one-third highest waves. The significant wave height can be related to other statistical heights by the following relations:

$$
\begin{aligned}
& H_{\max }=1.77 \mathrm{H}_{\mathrm{S}} \\
& \mathrm{H}_{1}=1.67 \mathrm{H}_{\mathrm{S}} \\
& H_{10}=1.27 \mathrm{H} \mathrm{S}
\end{aligned}
$$

where $H_{S}$ is the significant wave height, $H_{\max }$ is the maximum wave height, $H_{1}$, is the average of the highest 1 percent of the waves, and $H_{10}$ is the average of 
TABLE 20. Highest Significant Wave Heights and Other Associated

Statistical Heights, Fort Point Station

\begin{tabular}{|c|c|c|c|c|}
\hline Direction & $\begin{array}{l}\mathrm{HS}_{\mathrm{S}}, \\
\mathrm{ft}\end{array}$ & $\begin{array}{c}H_{\max }, \\
\mathrm{ft} \\
\end{array}$ & $\begin{array}{l}\mathrm{H}_{1}, \\
\mathrm{ft} \\
\end{array}$ & $\begin{array}{c}\mathrm{H}_{10}, \\
\mathrm{ft} \\
\end{array}$ \\
\hline SSW & 1.2 & 2.1 & 2.0 & 1.5 \\
\hline SW & 3.2 & 5.7 & 5.3 & 4.1 \\
\hline WSW & 3.8 & 6.7 & 6.3 & 4.8 \\
\hline W & 4.3 & 7.6 & 7.2 & 5.5 \\
\hline WNW & 5.2 & 9.2 & 8.7 & 6.6 \\
\hline NW & 2.2 & 3.9 & 3.7 & 2.8 \\
\hline NNW & 2.5 & 4.4 & 4.2 & 3.2 \\
\hline $\mathrm{N}$ & 3.1 & 5.5 & 5.2 & 3.9 \\
\hline NNE & 2.9 & 5.1 & 4.8 & 3.7 \\
\hline $\mathrm{NE}$ & 2.8 & 5.0 & 4.7 & 3.6 \\
\hline ENE & 2.6 & 4.6 & 4.3 & 3.3 \\
\hline $\mathrm{E}$ & 2.0 & 3.5 & 3.3 & 2.5 \\
\hline ESE & 1.5 & 2.7 & 2.5 & 1.9 \\
\hline
\end{tabular}

the highest 10 percent of the waves. These other statistical wave heights are compared to the significant heights in Table 20. For rigid structures, such as concrete seawalls, the design wave height is normally based on the average of the highest 1 percent of the waves $\left(H_{1}\right)$. For semi-rigid structures, such as sheet pile structures, the average of the highest 10 percent of the waves $\left(H_{10}\right)$ are used for developing the design wave height. For flexible structures, such as rubble mound breakwaters, the significant wave height $\left(H_{S}\right)$ is often used as the design wave height.

The largest wave to impinge on the Fort Point Station is from the west northwest with a significant wave height of 5.2 feet. The corresponding maximum wave height is 9.2 feet. This wave will be used as the design wave for all-weather moorings at Fort Point Station. The characteristics of the Fort Point Station design wave are as follows:

$$
\begin{array}{ll}
\text { Wave Direction in Deep Water } & =W N W \\
\text { Wave Direction at Fort Point Station } & =N N W \\
\text { Wave Period } & =13 \mathrm{sec}
\end{array}
$$


Wave Length

Deepwater Wave Height

Significant Height at Fort Point Station

Maximum Height at Fort Point Station
$=282 \mathrm{ft}$

$=26 \mathrm{ft}$

$=5.2 \mathrm{ft}$

$=9.2 \mathrm{ft}$

\section{CREST ELEVATION OF STRUCTURE}

The height of a structure in the nearshore zone is normally determined by the vertical height above the stillwater level to which water from an incident wave will run up the face of the structure. Runup depends on structure shape and roughness, water depth at the toe of the structure, bottom slope in front of the structure, and incident wave characteristics. Using methods described in the Shore Protection Manual (Ref. 8) the runup at Fort Point Station can be calculated for a rubble mound structure with side slopes of $1-1 / 2: 1$, depth of 10 feet at toe of structure, design wave height of 5.2 feet, and period of 13 seconds when the water level at the highest estimated tide is 8.5 feet above MLLW. The corresponding runup on this structure would be 6.5 feet. Superimposing the runup on the highest estimated tide level of 8.5 feet, the required top elevation of a structure to prevent wave overtopping is 15 feet above MLLW.

WAVE HEIGHTS WITHIN ALL-WEATHER MOORINGS BASIN

Even though an all-weather moorings basin may be almost completely enclosed by some structural feature, water surface perturbations may occur within the basin due to diffraction of waves through the entrance channel, transmission of waves through a semi-permeable structure, or development of resonant waves (surge) within the basin.

Wave Transmission Through Structure and Resonance

When an incident wave strikes a structure, wave energy will be either reflected from, dissipated on, or transmitted through or over it. Ideally, breakwaters should reflect or dissipate all the wave energy to prevent damaging waves and resonance within the basin. Generally, this can be accomplished by designing the structure to prevent wave overtopping (see section on crest 
elevation of structure) and constructing an impermeable structure to prevent waves from being transmitted through it.

A structure at Fort Point Station, located in 10 feet of water at mean lower low water, would have to have a crest elevation of 15 feet above MLLW to prevent overtopping of the design wave of 5.2 feet and period of 13 seconds. If a structure were built with a lower crest elevation, waves would be transmitted into the basin due to overtopping. For example, with a crest elevation of +12 feet, MLLW, and crest width of 10 feet, the transmitted wave height would be somewhat greater than 0.4 times the incident wave height (Figure 7-39, Ref. 8). The resulting wave height in the basin, using the design wave of 5.2 feet, would be greater than 2 feet.

A permeable breakwater also allows waves to be transmitted through the breakwater even though the structure may have been designed for non-overtopping conditions. Using the same wave considerations as stated previously, the transmitted wave height through a permeable structure at Fort Point Station would be about 0.3 times the incident wave height, or about 1.6 feet (Figure 7-41, Ref. 8).

Generally, the wave heights within an all-weather moorings basin should be reduced to less than 1 foot. To accomplish this at Fort Point Station for the design wave conditions, the structure should be constructed to prevent wave overtopping, and should be constructed with an impermeable core. These design considerations will also greatly reduce the possibility of resonance within the all-weather moorings basin.

Wave Diffraction Within Basin

Wave diffraction within an all-weather moorings basin is dependent on the incident wave length, width of the entrance channel relative to the incident wave length, and orientation of the entrance relative to the incident wave fronts. Wave diffraction at Fort Point Station has been analyzed for the detached breakwater and shore-connected breakwater alternatives. The analysis of wave diffraction for the dredged basin alternative was not performed because the length and narrowness of the jetties would essentially dampen out any diffraction in the berthing area. The diffraction analysis was performed in 
accordance with the "Shore Protection Manual" (Ref. 8). The analysis was performed for all the wave fetches in Table 20 and for three different orientations of the entrance channel. These orienttions are to the east southeast (shore parallel), north northeast (perpendicular to shoreline) and west northwest (shore parallel). Tables 21, 22, and 23 are computed diffraction coefficients for each of the three breakwater configurations analyzed. The diffraction coefficients are given for the three different entrance channel orientations. The incident wave period and heights were taken from Table 20. The diffraction coefficients were computed at the berths and represent wave conditions that would be encountered while the SAR vessels were tied up during design wave conditions from each of the wave fetches.

Wave diffraction coefficients are similar for each of the breakwater configurations and entrance channel orientations. The diffraction coefficients vary from less than 0.1 to 1.0 . The diffraction coefficients are highest for those fetches directly in line with the orientation of the entrance channel. Since the incident wave heights are the lowest from the east southeast fetch, the diffracted wave height within the all-weather moorings basin would also be the lowest with an entrance channel orientation to the east southeast. Even with the east southeast orientation of the entrance, the wave height reductions are fairly small (high diffraction coefficients) for waves from the northeast through east southeast. These large diffraction coefficients are due to the small size of the basin, necessitating the placement of the berths close to the entrance. Diffracted wave heights will be discussed further in the section on entrance channel orientation.

LONGSHORE SEDIMENT TRANSPORT AND SHORELINE READJUSTMENT

Transport of sediment by waves and currents were discussed previously in the section on longshore transport. The estimated "potential" longshore sediment transport rates along the Fort Point Station shoreline are about $75,000 \mathrm{cy} / \mathrm{yr}$. There is a large easterly transport predominance, amounting to about $73,000 \mathrm{cy} / \mathrm{yr}$, as a result of long-period waves being transmitted through Golden Gate Strait. The "potential" transport rates are the maximum volume 
TABLE 21. Wave Diffraction Coefficients - Detached Breakwater, Circular Configuration

\begin{tabular}{|c|c|c|c|c|c|}
\hline \multirow[b]{2}{*}{$\begin{array}{c}\text { Fetch } \\
\text { Direction }\end{array}$} & \multirow[b]{2}{*}{$\frac{\text { Incident }}{\text { Period }}$} & \multirow[b]{2}{*}{$\frac{\text { Wave }}{\text { Height }}$} & \multicolumn{3}{|c|}{ Diffraction Coefficient } \\
\hline & & & $\begin{array}{c}E S E \\
\text { Orientation }\end{array}$ & $\begin{array}{c}\text { NNE } \\
\text { Orientation } \\
\end{array}$ & $\begin{array}{c}\text { WNW } \\
\text { Orientation } \\
\end{array}$ \\
\hline SSW & 8 & 1.2 & $<0.1$ & 0.55 & 0.6 \\
\hline SW & 16 & 3.2 & $<0.1$ & 0.55 & 0.6 \\
\hline SWS & 13 & 3.8 & $<0.1$ & 0.55 & 0.6 \\
\hline W & 13 & 4.3 & $<0.1$ & 0.55 & 0.6 \\
\hline WNW & 13 & 5.2 & $<0.1$ & 0.55 & 0.6 \\
\hline NW & 3 & 2.2 & $<0.1$ & 0.5 & 0.8 \\
\hline NNW & 3 & 2.5 & $<0.1$ & 0.6 & 0.6 \\
\hline $\mathrm{N}$ & 3.5 & 3.1 & $<0.1$ & 0.8 & 0.5 \\
\hline NNE & 3.5 & 2.9 & $<0.1$ & 0.95 & $<0.1$ \\
\hline NE & 3.5 & 2.8 & 0.5 & 0.8 & $<0.1$ \\
\hline ENE & 3.5 & 2.6 & 0.6 & 0.6 & $<0.1$ \\
\hline$E$ & 3.0 & 2.0 & 0.8 & 0.5 & $<0.1$ \\
\hline ESE & 2.5 & 1.5 & 0.95 & $<0.1$ & $<0.1$ \\
\hline
\end{tabular}

TABLE 22. Wave Diffraction Coefficients - Detached Breakwater, Triangular Configuration

\begin{tabular}{|c|c|c|c|c|c|}
\hline \multirow{3}{*}{$\begin{array}{c}\text { Fetch } \\
\text { Direction }\end{array}$} & \multirow[b]{2}{*}{ Incident } & \multirow[b]{2}{*}{ Wave } & \multicolumn{3}{|c|}{ Diffraction Coefficient } \\
\hline & & & ESE & NNE & WNW \\
\hline & Period & Height & Orientation & Orientation & Orientation \\
\hline SSW & 10 & 1.2 & $<0.1$ & 0.4 & 0.5 \\
\hline SW & 13 & 3.2 & $<0.1$ & 0.4 & 0.5 \\
\hline SWS & 13 & 3.8 & $<0.1$ & 0.4 & 0.5 \\
\hline W & 13 & 4.3 & $<0.1$ & 0.4 & 0.5 \\
\hline WNW & 13 & 5.2 & $<0.1$ & 0.4 & 0.5 \\
\hline NW & 3 & 2.2 & $<0.1$ & 0.6 & 0.9 \\
\hline NNW & 3 & 2.5 & $<0.1$ & 0.7 & 0.7 \\
\hline $\mathrm{N}$ & 3.5 & 3.1 & $<0.1$ & 0.9 & 0.6 \\
\hline NNE & 3.5 & 2.9 & $<0.1$ & 1.0 & $<0.1$ \\
\hline $\mathrm{NE}$ & 3.5 & 2.8 & 0.6 & 0.9 & $<0.1$ \\
\hline ENE & 3.5 & 2.6 & 0.7 & 0.7 & $<0.1$ \\
\hline $\mathrm{E}$ & 3.0 & 2.0 & 0.9 & 0.6 & $<0.1$ \\
\hline ESE & 2.5 & 1.5 & 1.0 & $<0.1$ & $<0.1$ \\
\hline
\end{tabular}


TABLE 23. Wave Diffraction Coefficients - Shore-Connected Breakwater

\begin{tabular}{|c|c|c|c|c|c|}
\hline \multirow{3}{*}{$\begin{array}{l}\text { Fetch } \\
\text { Direction }\end{array}$} & \multirow[b]{2}{*}{ Incident } & \multirow[b]{2}{*}{ Wave } & \multicolumn{3}{|c|}{ Diffraction Coefficient } \\
\hline & & & ESE & NNE & WNW \\
\hline & Period & Height & Orientation & Orientation & Orientation \\
\hline SSW & 10 & 1.2 & $<0.1$ & 0.4 & 0.5 \\
\hline SW & 13 & 3.2 & $<0.1$ & 0.4 & 0.5 \\
\hline WSW & 13 & 3.8 & $<0.1$ & 0.4 & 0.5 \\
\hline W & 13 & 4.3 & $<0.1$ & 0.4 & 0.5 \\
\hline WNW & 13 & 5.2 & $<0.1$ & 0.4 & 0.5 \\
\hline $\mathrm{NW}$ & 3 & 2.2 & $<0.1$ & $<0.1$ & 0.7 \\
\hline NNW & 3 & 2.5 & $<0.1$ & 0.4 & 0.6 \\
\hline $\mathrm{N}$ & 3.5 & 3.1 & $<0.1$ & 0.3 & 0.4 \\
\hline NNE & 3.5 & 2.9 & $<0.1$ & 0.65 & $<0.1$ \\
\hline NE & 3.5 & 2.8 & 0.4 & 0.85 & $<0.1$ \\
\hline ENE & 3.5 & 2.6 & 0.3 & 0.7 & $<0.7$ \\
\hline $\mathrm{E}$ & 3.0 & 2.0 & 0.65 & 0.6 & $<0.1$ \\
\hline ESE & 2.5 & 1.5 & 0.85 & 0.4 & $<0.1$ \\
\hline
\end{tabular}

of sand that can be transported for the prevailing wave conditions. In most cases, the actual volume of sand being transported by waves would be less than the computed "potential" transport rates due to the availability of sediments to be transported. When evaluating the effects of all-weather moorings construction on shoreline processes the "potential" rate will be used because it represents the "worst case" condition.

The source of the Fort Point Station beach sediments is an important consideration in the evaluation of the effects of all-weather moorings construction on shoreline processes. For example, if the source of beach sediments is exclusively from sediments being transported around Fort Point, any structure across the beach will be a physical barrier to the transport of sediments along the beach. Consequently, beach sediment would be deposited on the updrift (west) side of the structure and compensating erosion would occur on the downdrift (east) side of the structure. On the other hand, if Presidio/ Alcatraz Shoal is the principle source of sediment for Fort Point Beach, then sediment would be transported onshore by tidal currents along the entire length of beach and a structure across the beach would not present a total physical barrier to the transport of beach sediments. The available information on tidal current velocities and patterns in the immediate vicinity of Fort Point Station is not sufficient to evaluate the contribution of beach sediments by 
Presidio/Alcatraz Shoal. Therefore, the "worst case" condition will again be used to evaluate the effects of all-weather moorings construction on shoreline processes. The "worst case" condition is where the beach sediments of Fort Point Beach are derived exclusively from sediment being transported to the east around Fort Point.

Longshore sediment transport by waves takes place within a narrow band along the shoreline defined by the width of shoreline over which waves break. The breaker zone is confined, in the most part, to the area between the highand low-water contours. Solid structures across the beach, therefore, will present a physical barrier to the transport of sediments along the beach. Two of the conceptual alternatives, shore-connected breakwater (Figure 25) and dredged basin (Figure 27), would present such a pnysical barrier. After construction of these structures beach sediment would accumulate on the updrift side (west) until such a time that the beach was extended seaward to a position where sand could be naturally by-passed around the seaward end of the structure. The rate of accumulation of beach sediment would equal the longshore sediment transport rate to the east since both structures would present total littoral barriers. Under the "worst case" condition the sediment accumulation rate at Fort Point Station for both the shore-connected breakwater and dredged basin would be about 73,000 cy/yr (Table 19). The period of time before natural sediment by-passing began would be substantially shorter for the dredged basin than for the shore-connected breakwater because of the difference in length of the structures. Once natural sediment by-passing began sediment would accumulate in the entrance channel of the dredged basin and shoreconnected breakwater, requiring that maintenance dredging be performed.

While sediment is accumulating on the updrift side of the dredged basin jetty and shore-connected breakwater alternatives, compensating erosion would occur on the downdrift side of these structures. The compensating erosion would be in the form of shoreline recession and loss of usable beach area along the 1-mile reach of shoreline between Fort Point Station and San Francisco Yacht Harbor. It is difficult to predict or quantify the loss of beach area; 
however, the initial losses would occur just downdrift (east) of the east jetty of the dredged basin and shore-connected breakwater, but with time would progress to the east.

The loss of beach on the downdrift side of the shore-connected breakwater or dredged basin could be mitigated by mechanically by-passing sand around the structures with either a hydraulic dredge or heavy equipment. Under the "worst case" condition, about $73,000 \mathrm{cy} / \mathrm{yr}$ of sand would have to be by-passed. Mechanical sand by-passing would not only decrease/eliminate degradation to downdrift beaches, but would also minimize the amount of maintenance dredging in the entrance channel of the all-weather moorings basin. Mechanical bypassing could well be a permit condition if either the shore-connected breakwater or dredged basin alternatives were selected. The reason being that the shoreline adjacent to the Fort Point Station is part of the National Park Service's Golden Gate National Recreational Area and is used extensively by the public. Assurances would probably have to be given by the U.S. Coast Guard that measures would be implemented to mitigate any adverse effects to the physical environment resulting from all-weather moorings construction.

The third conceptual design alternative, the detached breakwater, would not present a total physical barrier to the longshore transport of sediments along Fort Point Beach, as long as the causeway connecting the breakwater to the shoreside facilities does not interrupt the movement of sediment along the beach. An open face pile structure, such as presently exists at the Station, would not present an appreciable barrier to the longshore transport of sediment. Some disruption of the longshore transport of sediment could occur, however, as a result of construction of a detached breakwater because of the formation of a wave shadow landward of the structure. Offshore structures along sandy beaches will generally cause an accumulation of sand in the wave shadow of the structure where it intersects the shoreline. The sand spit, thus formed, often referred to as a tombolo, is the result of decreased wave heights in the lee of the structure, decreasing the longshore component of wave energy. As with a physical barrier across the beach, compensating erosion will occur downdrift of the tombolo. The degree of disruption to the longshore sediment transport rates due to an offshore structure depends on the size of 
the structure, distance the structure is placed offshore and the angle of wave approach. The smaller the structure and further offshore the structure is placed, the smaller will be the wave shadow on the shoreline. Also the effective distance of the structure from the shoreline increases with increasing steepness of wave approach to the shoreline, again decreasing the effects of the wave shadow.

In the case of a detached breakwater at Fort Point Station, the wave shadow on the beach would be very small or nonexistent because the size of the basin is small in comparison to the wave length of waves responsible for the longshore transport of sediment along Fort Point Beach. Placement of the detached breakwater at least 350 feet offshore would further decrease the wave shadow, and the angle of approach of long-period waves to the shoreline at Fort Point Station is very steep, decreasing the effect of the wave shadow even further.

In summary, of the three conceptual alternatives, the construction of a detached breakwater would result in the least disruption to the existing longshore sediment transport rates and patterns. The shoreline readjustment at Fort Point Beach would at most be only slight with some sand accumulation occurring shoreward of the detached breakwater and some compensating erosion of beach sediment to the east of Fort Point Station. These slight readjustments would more than likely be masked by seasonal changes in beach conditions and would not be noticeable to the casual observer. The dredged basin and shoreconnected breakwater alternatives, on the other hand, would probably require some form of mechanically by-passing sand around the structures to prevent downdrift erosion of the beach and to prevent shoaling of the entrance channel.

\section{ENTRANCE CHANNEL ORIENTATION}

Wave heights within the all-weather moorings basin and potential shoaling within the basin are the two principal considerations when selecting the location of the entrance channel to the basin.

The entrance channel should be aligned, if at all possible, toward the wave fetch of minimum wave heights. Based on Tabie 20, the least exposed wave fetches at Fort Point Station are those from the east, east southeast and south 
southwest. The highest significant wave heights from these fetches are two feet or less. Orientation of the entrance channel to the east or east southeast would be parallel to the shoreline and away from the Golden Gate Strait. This orientation would be feasible for both the shore-connected breakwater and detached breakwater alternatives. Orientation of the entrance channel to the south southwest would not be feasible for the shore-connected breakwater and dredged basin alternatives, nor would it be practical for the detached breakwater alternative since the SAR vessels would have to manuever toward the shore upon entering and existing the basin.

Wave diffraction analysis within the all-weather moorings basin has been previously discussed in the section on wave heights within all-weather moorings basin. Diffracted wave heights at the SAR berths for the detached breakwaters (circular and triangular configuration) and shore-connected breakwater are given in Tables 24, 25, and 26. Although as indicated in Tables 21 through 23, the diffraction coefficients for the different breakwater configurations and entrance channel orientations are about the same, the diffracted wave heights vary significantly for the different entrance channel orientations. Diffracted wave heights within the all-weather moorings basins can be as high as 2.9 feet for an entrance channel exposure to the north northeast, and 3.1 feet for an entrance channel exposure to the WNW. The diffracted wave heights within the basins are least for an entrance channel exposure to the east southeast. The diffracted wave heights for the highest significant wave heights in Table 20 for an east southeast exposure vary from less than 1 foot to 1.6 feet for a detached breakwater with a circular configuration; from less than 1 foot to 1.8 feet for a detached breakwater with a triangular configuration; and from less than 1 foot to 1.3 feet for a shore-connected breakwater.

These diffracted wave heights for the east southeast exposure of the entrance channel in some cases exceed the preferred allowable wave height within the basin. The reason for these diffracted wave heights exceeding 1 foot is that the vessel berths are close to and in line with the entrance channel. In order to further decrease the diffracted wave heights, the basin 
TABLE 24. Diffracted Wave Heights Within Detached Breakwater, Circular Configuration

\begin{tabular}{|c|c|c|c|c|c|}
\hline \multirow[b]{2}{*}{$\begin{array}{c}\text { Fetch } \\
\text { Direction }\end{array}$} & \multicolumn{2}{|c|}{ Incident Wave } & \multicolumn{3}{|c|}{ Diffraction Wave Height (ft) } \\
\hline & $\begin{array}{l}\text { Period } \\
\text { sec } \\
\end{array}$ & $\begin{array}{l}\text { Height } \\
\mathrm{ft} \\
\end{array}$ & $\begin{array}{c}\text { ESE } \\
\text { Orientation }\end{array}$ & $\begin{array}{c}\text { NNE } \\
\text { Orientation }\end{array}$ & $\begin{array}{c}\text { WNW } \\
\text { Orientation } \\
\end{array}$ \\
\hline SSW & 8 & 1.2 & $<1$ & $<1$ & $<1$ \\
\hline SW & 16 & 3.2 & $<1$ & $<1.8$ & 1.9 \\
\hline WSW & 13 & 3.8 & $<1$ & 2.1 & 2.3 \\
\hline$W$ & 13 & 4.3 & $<1$ & 2.4 & 2.6 \\
\hline WNW & 13 & 5.2 & $<1$ & 2.9 & 3.1 \\
\hline NW & 3 & 2.2 & $<1$ & 1.1 & 1.8 \\
\hline NNW & 3 & 2.5 & $<1$ & 1.5 & 1.5 \\
\hline $\mathrm{N}$ & 3.5 & 3.1 & $<1$ & 2.5 & 1.6 \\
\hline NNE & 3.5 & 2.9 & $<1$ & 2.8 & $<1$ \\
\hline $\mathrm{NE}$ & 3.5 & 2.8 & 1.4 & 2.2 & $<1$ \\
\hline ENE & 3.5 & 2.6 & 1.6 & 1.6 & $<1$ \\
\hline $\mathrm{E}$ & 3.0 & 2.0 & 1.6 & 1.0 & $<1$ \\
\hline ESE & 2.5 & 1.5 & 1.4 & $<1$ & $<1$ \\
\hline
\end{tabular}

TABLE 25. Diffracted Wave Heights Within Detached Breakwater, Triangular Configuration

\begin{tabular}{|c|c|c|c|c|c|}
\hline \multirow{2}{*}{$\begin{array}{c}\text { Fetch } \\
\text { Direction } \\
\end{array}$} & \multicolumn{2}{|c|}{ Incident Wave } & \multicolumn{3}{|c|}{ Diffraction Wave Height (ft) } \\
\hline & $\begin{array}{l}\text { Period } \\
\text { sec }\end{array}$ & $\begin{array}{l}\text { Height } \\
\mathrm{ft}\end{array}$ & $\begin{array}{c}\text { ESE } \\
\text { Orientation }\end{array}$ & $\begin{array}{c}\text { NNE } \\
\text { Orientation } \\
\end{array}$ & $\begin{array}{c}\text { WNW } \\
\text { Orientation }\end{array}$ \\
\hline SSW & 8 & 1.2 & $<1$ & $<1$ & $<1$ \\
\hline SW & 16 & 3.2 & $<1$ & 1.3 & 1.6 \\
\hline WSW & 13 & 3.8 & $<1$ & 1.5 & 1.9 \\
\hline WNW & 13 & 5.2 & $<1$ & 1.7 & 2.2 \\
\hline NW & 3 & 2.2 & $<1$ & 1.3 & 2.0 \\
\hline NNW & 3 & 2.5 & $<1$ & 1.8 & .. .8 \\
\hline N & 3.5 & 2.9 & $<1$ & 2.8 & 1.9 \\
\hline NNE & 3.5 & 2.9 & $<1$ & 2.9 & $<1$ \\
\hline $\mathrm{NE}$ & 3.5 & 2.8 & 1.7 & 2.5 & $<1$ \\
\hline ENE & 3.5 & 2.6 & 1.8 & 1.8 & $<1$ \\
\hline $\mathrm{E}$ & 3.0 & 2.0 & 1.8 & 1.2 & $<1$ \\
\hline ESE & 2.5 & 1.5 & 1.5 & $<1$ & $<1$ \\
\hline
\end{tabular}


TABLE 26. Diffracted Wave Heights Within Shore Connected Breakwater

\begin{tabular}{|c|c|c|c|c|c|}
\hline \multirow[b]{2}{*}{$\begin{array}{c}\text { Fetch } \\
\text { Direction }\end{array}$} & \multirow{2}{*}{$\begin{array}{l}\text { Inciden } \\
\text { Period } \\
\text { sec } \\
\end{array}$} & \multirow{2}{*}{$\begin{array}{c}\text { Wave } \\
\text { Height } \\
\text { ft }\end{array}$} & \multicolumn{3}{|c|}{ Diffraction Wave Height (ft) } \\
\hline & & & $\begin{array}{c}\text { ESE } \\
\text { Orientation }\end{array}$ & $\begin{array}{c}\text { NNE } \\
\text { Orientation }\end{array}$ & $\begin{array}{c}\text { WNW } \\
\text { Orientation }\end{array}$ \\
\hline SSW & 8 & 1.2 & $<1$ & $<1$ & $<1$ \\
\hline SW & 16 & 3.2 & $<1$ & 1.3 & 1.6 \\
\hline WSW & 13 & 3.8 & $<1$ & 1.5 & 1.9 \\
\hline W & 13 & 4.3 & $<1$ & 1.7 & 2.2 \\
\hline WNW & 13 & 5.2 & $<1$ & 2.1 & 2.6 \\
\hline NW & 3 & 2.2 & $<1$ & $<1$ & 1.5 \\
\hline NNW & 3 & 2.5 & $<1$ & 1.0 & 1.5 \\
\hline$N$ & 3.5 & 3.1 & $<1$ & $<1$ & 1.2 \\
\hline NNE & 3.5 & 2.9 & $<1$ & 1.9 & $<1$ \\
\hline$N E$ & 3.5 & 2.8 & 1.1 & 2.4 & $<1$ \\
\hline ENE & 3.5 & 2.6 & $<1$ & 1.8 & $<1$ \\
\hline$E$ & 3.0 & 2.0 & 1.3 & 1.2 & $<1$ \\
\hline ESE & 2.5 & 1.5 & 1.3 & 1.3 & $<1$ \\
\hline
\end{tabular}

would have to be larger or a secondary wave attenuator would have to be placed in front of the entrance channel so that the incident waves would have to be diffracted twice before entering the berthing area of the all-weather moorings basin. The wave attenuator would further decrease the diffracted wave height by about $50 \%$, thereby reducing the wave heights within the basin to less than 1 foot.

MAINTENANCE DREDGING REQUIREMENTS

There are three potential sources of sediment which could accumulate in an al1-weather moorings basin at Fort Point Station, eventually requiring maintenance dredging of the basin to provide unhindered movement of SAR vessels. These sources of sediments are: sediment being transported along the shoreline by waves, sediments being transported as bed load in the nearshore zone by tidal currents, and sediments in suspension in the water column.

Longshore sediment transport volumes have been previously computed, and the effect on the three conceptual design alternatives evaluated. The potential shoaling within the entrance channel and basin from sediments being transported alongshore is high for the dredged basin and shore-connected breakwater alternatives, where these structures would present an almost total physical 
barrier to the longshore transport of sediment along Fort Point Beach. Under the "worst case" condition as much as 75,000 cy of sediment could be trapped annually on the updrift (west) side of these structures. If these sediments were not physically by-passed around the structures, natural by-passing would occur within a fairly short time period (on the onder of 1 to 5 years), allowing the sediments to be transported and deposited within the entrance channel and basin. In contrast, the deposition within the entrance channel and basin of a detached breakwater from this source would be very small to nonexistent, due to the placement of the structure offshore. By placing the structure offshore, the longshore sediment transport rates would be minimally affected, especially if the structure is small in comparison to the design wave length and is placed as far offshore as possible.

The other two potential sources of shoal material, bed sediments transported by tidal currents and suspended sediment, would be small in comparison to longshore sediment transport by waves, but could be important when evaluating maintenance dredging requirements for the detached breakwater alternative.

Bed sediment transport by tidal currents has been discussed in the section of sediment sources and transport. This analysis was based on the nearest available tidal current velocity data to Fort Point Station, located in about 50 feet of water about 0.5 miles offshore of the station. A reversal in the direction of the current is known to exist in the immediate vicinity of the Station during both flood and ebb tides, and the current velocities are likely to be less than those measured offshore. Because of the lack of current data in the immediate vicinity of the Station, the offshore current velocity magnitude during flood and ebb tides well be used as a "worst case" condition to evaluate potential shoaling in the all-weather moorings basin from this source. Since current reversals occur in the immediate vicinity of fort Point Station during ebb tide, bed sediments could directly enter the all-weather moorings basin on ebb tide if the entrance channel were oriented to the west northwest. With an estimated annual bed sediment transport rate of 7.4 tons per year per foot of width and an effective bottom width of the entrance channel of about 10 feet, approximately 75 tons of sediment could be carried into the basin by bed load transport during ebb tide in a year. Using a conversion 
factor of 1.35 tons per cubic yard, approximately 55 cubic yards of sediment per year could accumulate in the basin. The effective bottom area for the triangular and circular detached breakwaters are, respectively, about 7200 square feet and 8000 square feet. If the bed load sediments were distributed uniformly in the basin upon entering, the annual decrease in depth (shoaling) would be about 2.5 inches per year for the triangular configuration and 2.2 inches per year for the circular configuration. The effective bottom area of the shore-connected breakwater is about double that of the detached breakwaters so the associated shoaling rate from bed load transport with a west northwest alignment would be about 1.2 inches per year. If the bed load sediment were the only source of shoaling sediment, and assuming the beginning depth in the basins was 10 feet below MLLW and that dredging would have to be undertaken when the depth decreased to 5 feet below MLLW, maintenance dredging would be required in from 25 to 30 years with a detached breakwater and in about 50 years with a shore-connected breakwater.

Bed load sediments could directly enter the all-weather moorings basin on flood tide with an entrance channel orientation to the east southeast. However, the annual volume of sediment transported as bed load by flood currents is very small and the annual shoaling rate from this source would be negligible. Shoaling rates within the dredged basin alternative from bed load transport by tidal currents would also be negligible since the current velocities entering the basin would not be great enough to transport bed sediments into the basin.

An estimate of the amount of suspended sediment entering an all-weather moorings can be made if the suspended sediment load and volume of water entering the basin during the flood tidal cycle are known. A "worst case" condition can then be evaluated by assuming that all the suspended load settles out once it enters the basin.

The average suspended sediment load exiting the Golden Gate Strait is 40 to 50 parts per million (ppm) (Ref. 19). The average tidal range at Fort Point Station is about 5.8 feet. The basin areas at mid-tide for the three conceptual alternatives range from $10,000 \mathrm{ft}^{2}$ for the dredged basin, to about $15,000 \mathrm{ft}^{2}$ for the detached breakwater, to $24,000 \mathrm{ft}^{2}$ for the shore-connected 
breakwater. The corresponding tidal prisms range from $52,000 \mathrm{ft}^{3}$ to $125,000 \mathrm{ft}^{3}$ of water that would enter the basins during each tidal cycle. Since there are two tidal cycles per day $104,000 \mathrm{ft}^{3}$ of water would enter and exit the dredged basin in a day, 156,000 $\mathrm{ft}^{3}$ of water would enter and exit the detached breakwater, and 250,000 $\mathrm{ft}^{3}$ of water would enter and exit the shoreconnected breakwater. Using an average value of $45 \mathrm{ppm}$ for the suspended sediment load about $5 \mathrm{ft}^{3}$ of suspended sediment would enter the dredged basin per day, $7 \mathrm{ft}^{3}$ of suspended sediment would enter the detached breakwater, and $11 \mathrm{ft}^{3}$ of suspended sediment would enter the shore-connected breakwater. Converting these into an annual shoaling rate by assuming that all the suspended sediment settled out in the basins, the annual decrease in water depth would be 2 inches per year for the three conceptual design alternatives.

Even using this "worst case" condition for shoaling due to suspended sediments entering the all-weather moorings basin, maintenance dredging would not be required for 30 years.

In summary, the principal source of shoal sediments for the dredged basin and shore-connected breakwaters would be from the longshore transport of sediment along Fort Point Beach by waves. Without mechanically by-passing sediment that would accumulate on the updrift side of these structures, the maintenance dredging requirements could be large once sediment; began to be naturally by-passed around the structures. For a detached breakwater with the entrance channel oriented to the east southeast, the principal source of shoal material would be from suspended sediments carried into the basin by tides. Under the "worst case" condition, maintenance dredging would be required about every 30 years. A detached breakwater with the entrance channel orientation to the west northwest would require maintenance dredging about every 15 years under the "worst case" condition. 
CONCLUSIONS

Based on an analysis of littoral processes along Fort Point Beach near the entrance to San Francisco Bay, it would be feasible to construct all-weather moorings at the U.S. Coast Guard Station, Fort Point. The wave conditions at Fort Point Station are such that long-period waves transmitted through Golden Gate Strait from the Pacific ocean at times make it extremely dangerous for the Search and Rescue crews to get off and on the Motor Life Boats, and it is difficult to perform routine maintenance on the vessels. Significant wave heights at the Station can exceed 5 feet with periods in excess of 10 seconds under design wave conditions. Wind-generated waves originating in the Bay can result in short-period waves exceeding 3 feet in height.

Three conceptual design alternatives: dredged basin, shore-connected breakwater and detached breakwater, were evaluated in terms of how construction would affect littoral processes. The dredged basin and shore-connected breakwater alternatives, although providing adequate wave protection, would present an almost total physical barrier to the longshore transport of sediments along Fort Point Beach. The construction of these two design alternatives would probably require that beach sediments be physically by-passed around the structures to decrease maintenance dredging requirements and to mitigate degradation (erosion) of downdrift beaches. The annual volume of sediment that would have to be physically by-passed could be as much as 75,000 cubic yards per year. The beach to the east (downdrift) of Fort Point Station is part of the National Park Service's Golden Gate National Recreational Area which is extensively used by the public.

A detached breakwater with the minimum required size for three Search and Rescue vessels placed as far offshore as possible could provide adequate wave protection while having very little if any effect on the Fort Point Beach. Access to the detached breakwater could be provided by an open face, pile causeway which would not interrupt the longshore transport of sediment by waves. The best orientation of the entrance channel for a detached breakwater would be to the east southeast, which is parallel to the shoreline and away from Golden Gate Strait. This orientation would provide the best wave 
protection and require the least amount of maintenance dredging. Diffracted wave heights within the detached breakwater under design wave conditions would be slightly in excess of 1 foot if the size of the structure was to meet the minimum requirements for three vessels. These wave heights could be reduced to less than 1 foot by placement of a sheet pile bulkhead off the entrance channel of the detached breakwater. 


\section{REFERENCES}

1. 0lmstead, Roger and Nancy. 1979. "Ocean Beach Study: A Survey of Historical Maps and Photographs," Prepared for the San Francisco Wastewater Management Program.

2. U.S. Department of Commerce, Environmental Sciences Services Administration. 1970. Climatography of the United States No. 60-4, Climate of California, Washington, D.C.

3. U.S. Department of Commerce, National Oceanographic and Atmospheric Administration. 1973. Environmental Conditions Within Specified Geographical Regions, Offshore East and West Coasts of the United States and in the Gulf of Mexico.

4. U.S. Department of Commerce, National Ocean Survey. Tide Tables, High and Low Water Levels, Pacific Coast of North and South America Including the Hawai ian Islands, Published Annually, U.S. Government Printing Office, Washington, DC.

5. U.S. Department of Commerce, National Ocean Survey. 1973. Tidal Current Charts - San Francisco Bay. Rockville, MD.

6. Sverdrup, H. U., and W. H. Munk. 1953. "Wind, Sea and Swe11; Theory of Relationships for Forecasting," Pub. No. 101, U.S. Navy Hydrographic Office, Washington, DC.

7. Bretschneider, C. L., and R. 0. Reid. 1962. "Change in Wave Height Due to Bottom Friction, Percolation and Refraction," 34th Annual Meeting of American Geophysics Union.

8. U.S. Army Corps of Engineers. 1977. Shore Protection Manua1, 3 Volumes, U.S. Government Printing Office, Washington, DC.

9. National Marine Consultants. 1960. Wave Statistics for Seven Deep Water Stations Along the California Coast.

10. National Marine Consultants. 1960. Wave Statistics for Ten Most Severe Storms Affecting Three Selected Stations of Northern California During the Period of 1951-1960.

11. Qualye, R. G., and D. C. Fishbright. 1975. Extreme Wind and Wave Return Periods for the U.S. Coast. Marine Weather Log (March), pp. 67-70.

12. Ecker, R. M. 1980. Ocean Beach Sand Replenishment Program, Towil1, Inc., Prepared for the City and County of San Francisco, Clean Water Program. 
13. Kachel, M. B., and R. W. Sternberg. 1971. Transport of Bedload as Ripples During an Ebb Current," Marine Geology, 19:229-244.

14. Sternberg, R. W. 1972. "Predicting Initial Motion and Bedload Transport of Sediment Particles in the Shallow Marine Environment," In

D. J. P. Swift, D. B. Duane, and 0. H. Pilkey, ed., Shelf Sediment Transport, Stroudsburg, Pennsylvania, Dowden, Hutchenson, and Ross, pp. 61-82.

15. Bagnold, R. A. 1963. "Mechanics of Marine Sedimentation" in M. N. Hill, ed. The Sea. Vol. 3, The Earth Beneath the Sea. New York, WileyInterscience, pp. 507-582.

16. Johnson, J.W. 1971. Bottom Sediment Characteristics Near Entrance to San Francisco Bay. Hydraulic Engineering Laboratory, HEL 24-3. University of California, Berkeley, CA.

17. Karim, F., and J. F. Kennedy. 1981. Computer-Based Predictors for Sediment Discharges and Friction Factors of Alluvial Streams, Iowa Institute of Hydraulic Research, IIHR Report No. 242, University of Iowa, Iowa City, IA.

18. Daley, J. W., and D. R. F. Harleman. 1966. Fluid Dynamics, AddisonWesley, Reading, Massachusetts.

19. U.S. Army Corps of Engineers. 1979. Dredge Disposal Study, San Francisco Bay and Estuary, Appendix B Pollutant Distribution, USACE, San Francisco District. 


\section{DISTR IBUTION}

No. of

Copies

OFFSITE

25 LCDR Gregg W. Sutton 12 th Coast Guard District Government Is land Alameda, CA 94501

27 DOE Technical Information Center
No. of

Copies

ONSITE

1 DOE Richland Operations Office

H. E. Ransom

17 Pacific Northwest Laboratory

R. M. Ecker (5)

G. Whel an (5)

Technical Information (5)

Publishing Coordination (5) 


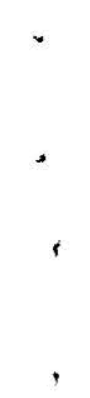

